\title{
THE POLITICS OF FOREIGN DIRECT INVESTMENT IN AUTHORITARIAN REGIMES
}

\author{
by

\section{Ida Bastiaens} \\ BA in Economics, Davidson College, 2007
}

\author{
Submitted to the Graduate Faculty of \\ Graduate School of Public and International Affairs in partial fulfillment \\ of the requirements for the degree of \\ Doctor of Philosophy
}

University of Pittsburgh 
UNIVERSITY OF PITTSBURGH

Graduate School of Public and International Affairs

This dissertation was presented

by

Ida Bastiaens

It was defended on

July 22, 2013

and approved by

Luke Condra, Assistant Professor, GSPIA

Jude Hays, Associate Professor, Political Science

Kevin Morrison, Assistant Professor, GSPIA

Thesis Director/Dissertation Advisor: Nita Rudra, Associate Professor, GSPIA 
Copyright (C) by Ida Bastiaens

2013 


\title{
THE POLITICS OF FOREIGN DIRECT INVESTMENT IN AUTHORITARIAN
}

\author{
REGIMES \\ Ida Bastiaens, $\mathrm{PhD}$ \\ University of Pittsburgh, 2013
}

Existing scholarship does not account for why foreign direct investment (FDI) inflows have been increasing to many authoritarian countries in recent decades, with some authoritarian developing countries attracting levels of FDI similar to those in democratic developing countries. This dissertation argues that while authoritarian countries are in general more risky than democratic countries, this risk can be minimized when authoritarian regimes are constrained from both "above" and "below." Authoritarian regimes that sign international investment treaties signal FDI-friendly policies and are constrained from backtracking on those policies. At the same time, authoritarian regimes that allow some degree of citizen participation in policymaking are constrained from deviating from FDI-friendly policies, which are generally preferred by citizens. In sum, it is hypothesized that authoritarian regimes that sign international investment treaties and maintain relatively high levels of citizen participation will attract the most FDI inflows. This hypothesis is tested using micro and macro level empirical evidence. Specifically, multilevel ordered probits of survey data on citizen preferences for FDI and statistical regressions of panel data on global FDI inflows are conducted. Estimation results confirm both the theoretical foundations and formal hypothesis of this dissertation: citizens in authoritarian countries view FDI inflows as welfare-enhancing and authoritarian countries with bilateral investment treaties and high levels of citizen participation attract the most FDI inflows. Additionally, results from an original survey of U.S. foreign investors reveal that multinational companies are aware of and value international investment treaties and freedom of association in host nations, thereby providing key primary evidence in support of the hypothesis. Finally, a comparative case study of Jordan and Syria further illustrate the micro-foundations of the argument. While both Jordan and Syria have signaled a dedication to liberal economic policies, Jordan has been the successor in attracting FDI inflows because of its participatory decision-making processes. This dissertation contributes to international political economy, international organization, and authoritarian political institution research by illuminating the domestic factors that provide credibility of compliance to international treaties signed by authoritarian countries. Previous literature has failed to address the variation of foreign investment inflows to authoritarian regimes and the role of compliance to international investment treaties in attracting these investment inflows to authoritarian countries. 
TABLE OF CONTENTS

ACKNOWLEDGMENTS ...........................................................................................................

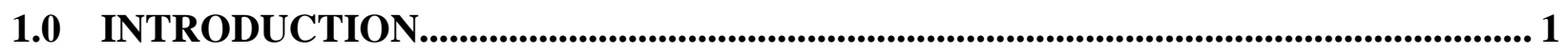

1.1 ARGUMENT AND STRUCTURE OF DISSERTATION ....................................... 4

1.2 SIGNIFICANCE OF DISSERTATION .......................................................................... 7

2.0 INTERNATIONAL INSTITUTIONS: THE ROLE OF BILATERAL INVESTMENT

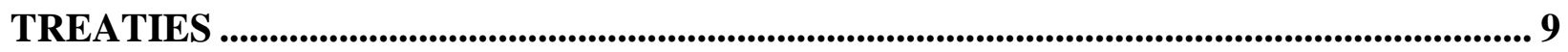

2.1 THE EFFECTIVENESS OF INTERNATIONAL INSTITUTIONS ..................... 11

2.2 ARGUMENT: BILATERAL INVESTMENT TREATIES AS A CREDIBLE

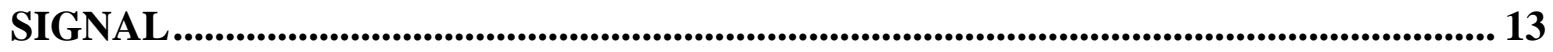

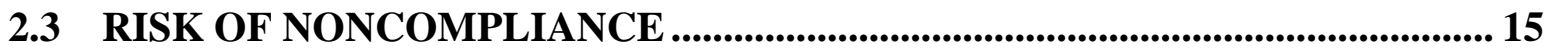

3.0 DOMESTIC INSTITUTIONS: THE ROLE OF CITIZEN PARTICIPATION.......... 19

3.1 ARGUMENT: CITIZEN PARTICIPATION AS A CONSTRAINT ON

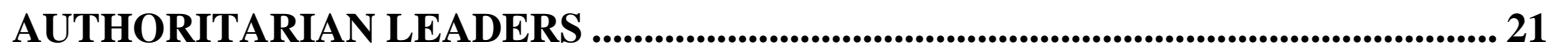

3.2 SOCIETAL FEEDBACK ON BENEFITS OF FDI ................................................... 25

3.3 FOREIGN INVESTORS AND CITIZEN PARTICIPATION ................................ 26

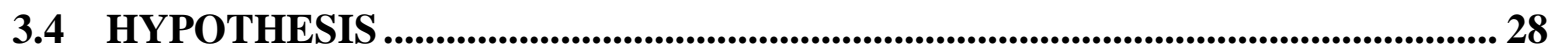

4.0 MICROFOUNDATIONS: CITIZEN AND BUSINESS PREFERENCES FOR FDI. 29

4.1 SURVEY EVIDENCE ON CITIZEN PREFERENCES ........................................... 29 
4.2 ORIGINAL SURVEY EVIDENCE ON BUSINESS PREFERENCES 34

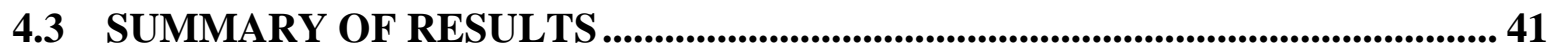

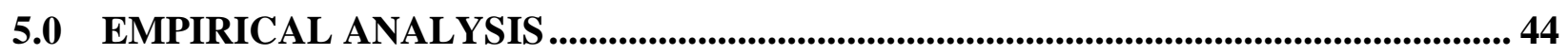

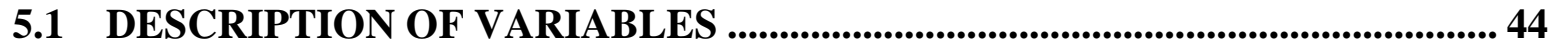

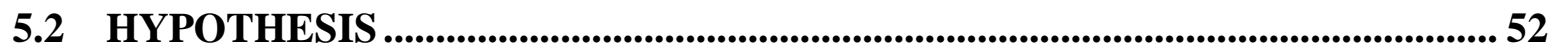

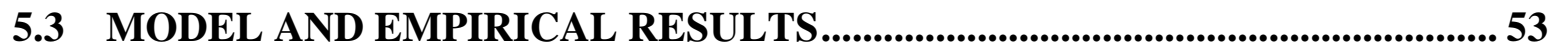

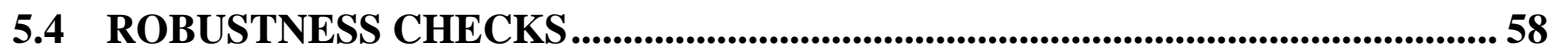

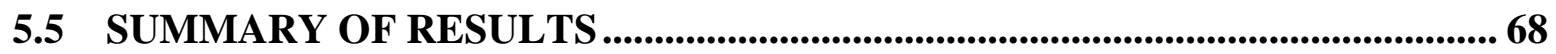

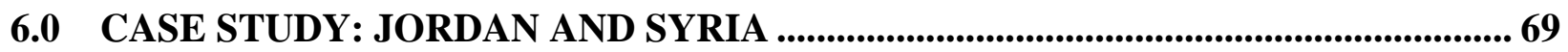

6.1 DECLARATION AND PUBLICATION OF FDI FRIENDLY POLICIES........ 72

6.2 DIFFERENCES IN CITIZEN PARTICIPATION ........................................... 75

6.3 FDI INFLOWS TO JORDAN AND SYRIA.................................................... 81

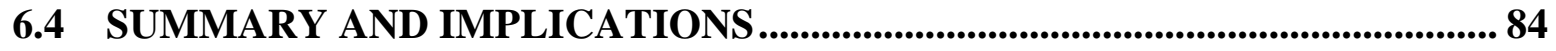

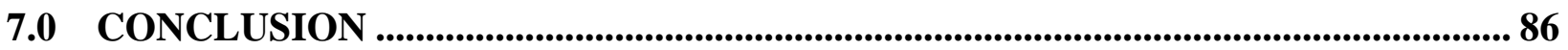

7.1 CHALLENGING CONVENTIONAL WISDOM .......................................... 87

7.2 AVENUES FOR FUTURE RESEARCH................................................................ 88

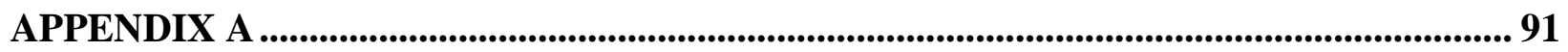

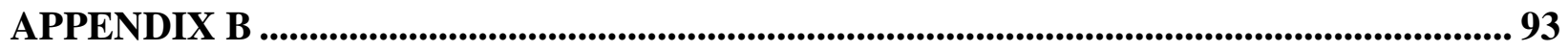

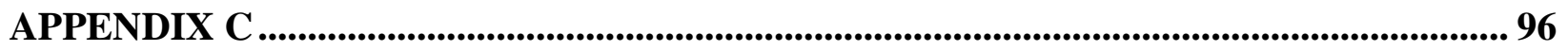

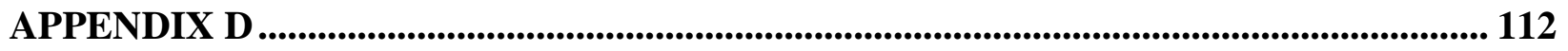

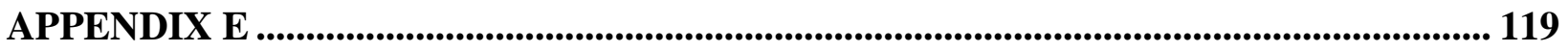

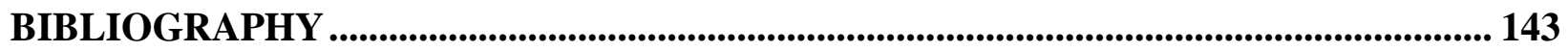




\section{LIST OF TABLES}

Table 1 Effect of FDI Inflows on Government Confidence in Authoritarian Countries: Multilevel

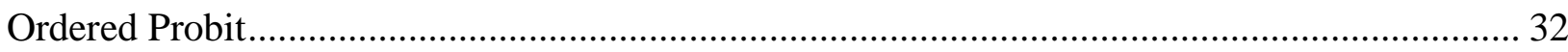

Table 2 Citizen Participation and Democracy in the Developing World in 2008 ..................... 47

Table 3 Determinants of Policy Stability in Authoritarian Countries: A Panel Regression......... 51

Table 4 Citizen Participation and BITs in Force in Authoritarian Countries in 2008 ................. 52

Table 5 Determinants of FDI Inflows to Authoritarian Countries: BITs and Citizen Participation

Table 6 Determinants of FDI Inflows to Authoritarian Countries: Formal Political Institutions. 65

Table 7 Jordan and Syria Comparison ........................................................................ 71

Table 8 Citizen Participation and BITs in Force in Jordan and Syria .................................... 71

Table 9 Effect of Inflows of FDI (US Dollars Logged) on Government Confidence ................. 93

Table 10 Effect of FDI Inflows on Government Confidence: No Objective Measure................ 94

Table 11 Effect of Inflows of FDI on Government Confidence: Polity Classification ............... 94

Table 12 Authoritarian Institutions Comparison in 2008 ................................................... 97

Table 13 Determinants of Rule of Law and Political Risk in Authoritarian Countries ............... 98

Table 14 Determinants of FDI Inflows (\% GDP) in Authoritarian Countries............................ 99

Table 15 Determinants of FDI Inflows to Non Resource Rich Authoritarian Countries ........... 100 
Table 16 Inflows of FDI to Resource Rich Authoritarian Countries. 101

Table 17 Determinants of FDI Inflows by Sector.......................................................... 102

Table 18 Determinants of FDI Inflows: Polity Classification ............................................. 102

Table 19 Determinants of FDI Inflows: All Developing Countries ....................................... 103

Table 20 Determinants of FDI Inflows: Fixed Effects Regression...................................... 104

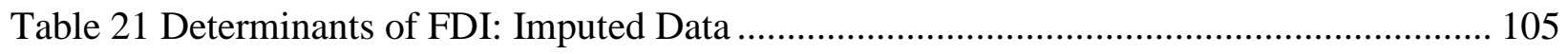

Table 22 Determinants of FDI Inflows: Arellano Bond Estimation..................................... 105

Table 23 Determinants of FDI Inflows: Instrumental Variable Regression ............................ 106

Table 24 Determinants of FDI Inflows: Selection Model ................................................. 107

Table 25 Determinants of FDI Inflows: Additional Controls............................................ 108

Table 26 Determinants of FDI Inflows: Strength of Enforcement Provisions in BITs ............. 109

Table 27 Determinants of FDI Inflows: BITs, Citizen Participation, and Formal Political

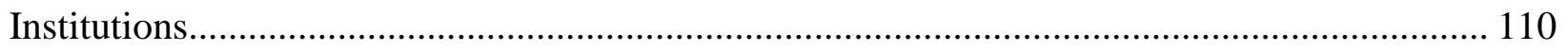

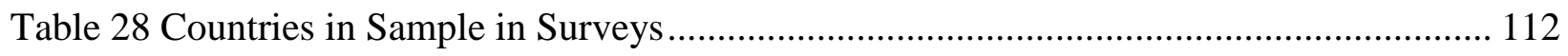

Table 29 Variable Descriptions for WVS Survey Models................................................. 112

Table 30 Variable Descriptions for Panel Regression Models ............................................. 113

Table 31 Countries in Sample in Panel Regressions ......................................................... 117 


\section{LIST OF FIGURES}

Figure 1 Average FDI Inflows (Current US Dollars) to Democratic and Authoritarian Countries 2

Figure 2 FDI Inflows (Current US Dollars) to Authoritarian Countries in 2008 ......................... 3

Figure 3 Citizen Preferences for FDI in Authoritarian Countries.......................................... 30

Figure 4 Predicted Probabilities of Respondents who Indicate Great Confidence in Government

Figure 5 Value of Domestic and International Institutions in Securing Property Rights and Profit 38

Figure 6 Value of BITs in Signaling a Commitment to Liberal Economic Policies ................... 39

Figure 7 How Often Businesses Work with Civil Society ................................................ 40

Figure 8 Business Perceptions of Citizen Support for FDI............................................... 41

Figure 9 Average Number of BITs in Force in Authoritarian Countries................................ 45

Figure 10 Number of BITs in Force in Authoritarian Countries in 2008 ............................... 46

Figure 11 Citizen Participation in Authoritarian Countries in 2008 ....................................... 48

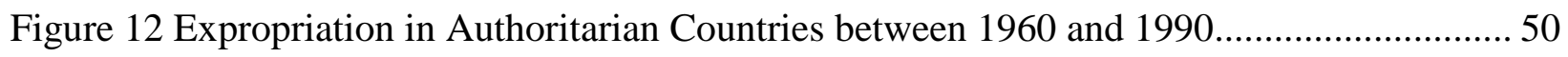

Figure 13 Marginal Effect of BITs on FDI Inflows (Conditional on Citizen Participation) ........ 56

Figure 14 Marginal Effect of BITs on FDI Inflows (Conditional on Legislature) ...................... 66

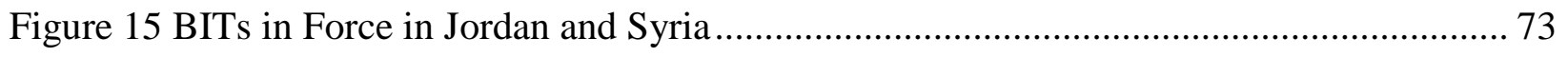


Figure 16 Citizen Participation in Jordan and Syria ........................................................... 76

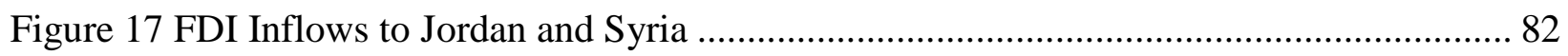

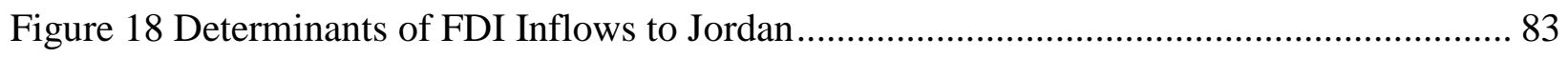

Figure 19 Determinants of FDI Inflows to Syria ............................................................. 83

Figure 20 Average FDI Inflows (Percent of GDP) to Democratic and Authoritarian Countries . 91

Figure 21 Rule of Law in Democratic and Authoritarian Countries ...................................... 92

Figure 22 Citizen Participation in Authoritarian Countries between 1990 and 2008................. 96

Figure 23 Legislatures in Authoritarian Countries between 1990 and 2008 .......................... 97

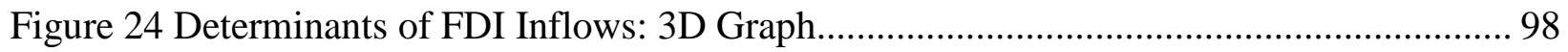

Figure 25 Marginal Effects of BITs on FDI Inflows to Non Resource Rich Authoritarian

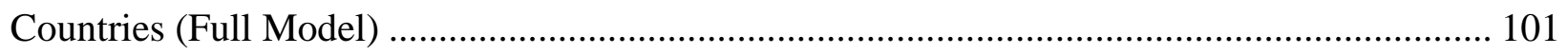




\section{ACKNOWLEDGMENTS}

I would like to thank my dissertation committee Nita Rudra, Luke Condra, Jude Hays, and Kevin Morrison for their thoughtful, challenging, and comprehensive comments. It is because of their guidance and encouragement that I have been able to complete this dissertation project. I wish to extend my most sincere and deepest thanks to my dissertation chair, Nita Rudra, who has taught me how to be organized and clear in my thinking, writing, and presentations, rigorous in my argument and empirics, and, most of all, passionate and creative about the work I am pursuing. My academic success is truly because of Nita's strong and unwavering support.

I would also like to thank the many scholars I have consulted regarding aspects of my dissertation at the University of Pittsburgh, conferences, and workshops. Thank you to Stephen Chaudoin, Matthew Fails, Steve Finkel, Ryan Gruaer, Nate Jensen, Pierre Landry, Annemie Maertens, Sera Linardi, Anibal Perez-Linan, Martin Staniland, Dan Tirone, Carey Treado, Steven Weymouth, and Joseph Wright. I wish to personally thank Dean Keeler and Jessica Hatherill for their help and support during my time at GSPIA.

Thank you to my friends and colleagues at the University of Pittsburgh for their most valuable and gracious support: David Bell, Brandon Boylan, Colin Clarke, Scott Cook, Jian Cui, Jonas Gamso, Monica Jacobo, Jonathan Jeong, Jikuo Lu, Leslie Marshall, Peace Medie, Shawna Metzger, Sarah Patton, Evgeny Postnikov, and Farhod Yuldashev.

A special thank you to my family and close friends who have remained my rocks and strength throughout this process- my parents, Jesse, Charlie, Jason, Mary, and Mike. Every day, despite the circumstances, they have showered me with love and encouragement. Thank you to Emilie, Gena, and Jaime for taking time out of their busy lives to assist me with their business expertise. 


\subsection{INTRODUCTION}

Why are multinational companies investing in authoritarian countries? In the past two decades, foreign direct investment (FDI) to authoritarian countries increased by a slightly faster rate than to democratic countries ${ }^{1}$. FDI inflows to authoritarian regimes increased by close to 20 percent between 1990 and 2008, while investments to developing democracies increased by 18 percent. Figure 1 below highlights how authoritarian countries are now attracting similar levels of FDI as democracies ${ }^{2}$.

\footnotetext{
${ }^{1}$ According to the World Bank (2011), foreign direct investment is defined as "net inflows of investment to acquire a lasting interest in or management control over an enterprise operating in an economy other than that of the investor. It is the sum of equity capital, reinvested earnings, other long-term capital, and short-term capital, as shown in the balance of payments.” In this analysis, a regime is defined as authoritarian if at least one of the following conditions hold: the chief executive is not elected, the legislature is not elected, there is no more than one party, the incumbents will have or already have held office continuously by virtue of elections for more than two terms or have held office without being elected for any duration of their current tenure in office, and until today or until the time when they were overthrown they had not lost an election (Przeworski, Alvarez, Cheibub, and Limongi 2000).

${ }^{2}$ Inflows of foreign direct investment as a percent of gross domestic product to democratic and authoritarian countries between 1970 and 2008 present a similar trend with both regimes attracting comparable levels of investment. See Figure 20 in Appendix A.
} 


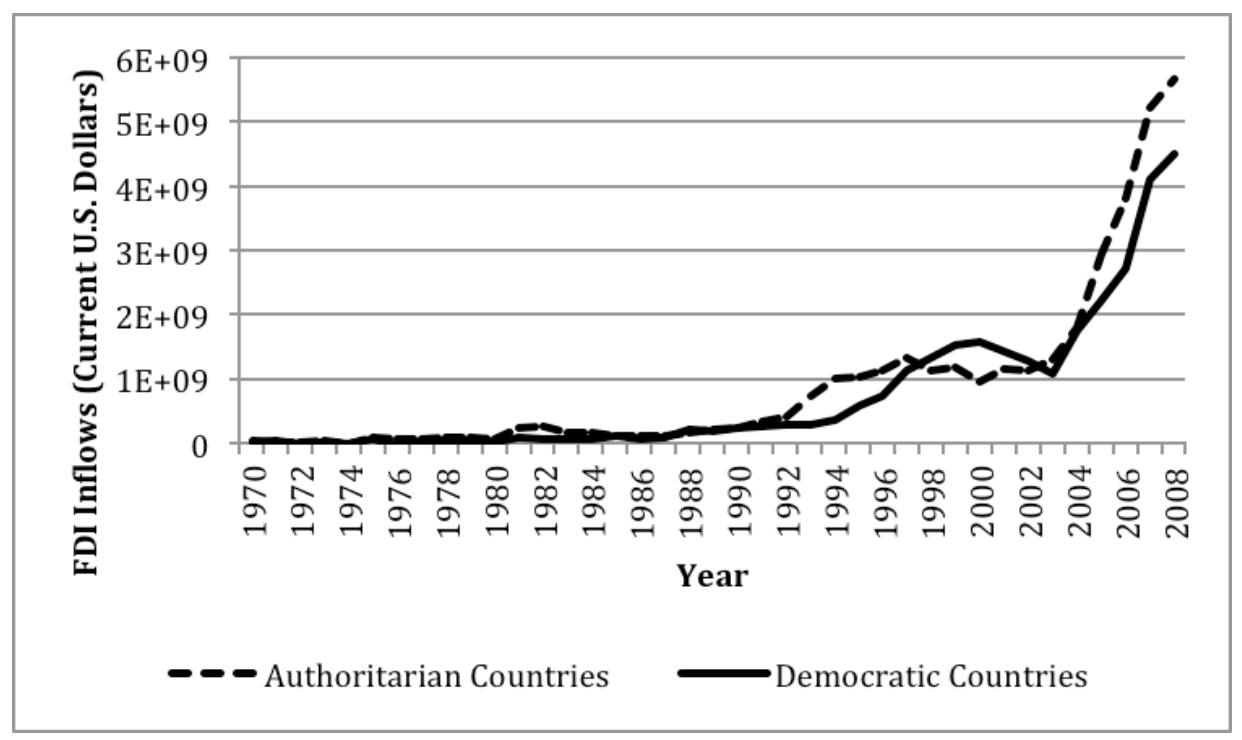

Figure 1 Average FDI Inflows (Current US Dollars) to Democratic and Authoritarian Countries ${ }^{3}$

Even more striking, resource rich countries do not constitute the majority of FDI flows. Oil rich states make up less than twenty percent of the sample ${ }^{4}$. Rather, non-resource rich countries such as China, Thailand, Singapore, and Lebanon have received 53 percent of FDI inflows to authoritarian countries since 1970 .

Recent scholarship overwhelmingly predicts that foreign investors invest in countries with strong property rights in order to ensure their assets are protected. Yet, more and more multinational companies are choosing to invest in authoritarian regimes with notoriously weak property right protections. Data indicates that the rule of law is low and stagnant in authoritarian countries in the past decade (see Figure 21 in Appendix A) ${ }^{5}$. Also, the rule of law remains

${ }^{3}$ Data is from World Bank (2011) and regime type is classified according to Cheibub et al (2009).

${ }^{4}$ Oil rich states are defined according to Ross (2012) as countries with annual oil and gas production valued greater than one hundred dollars per capita.

${ }^{5}$ The rule of law "captures perceptions of the extent to which agents have confidence in and abide by the rules of society, and in particular the quality of contract enforcement, property 
considerably lower than developing democracies. Thus, there is a risk of weak contract enforcement and property right protections in authoritarian countries.

Although, in general, authoritarian governments are not reliable to respect the rule of law, authoritarian countries are attracting great inflows of foreign direct investment (as seen in Figure 1). However, within this aggregate increase of FDI to authoritarian regimes there exists variation in inflows. Figure 2 below presents the variation of FDI inflows to authoritarian countries in 2008.

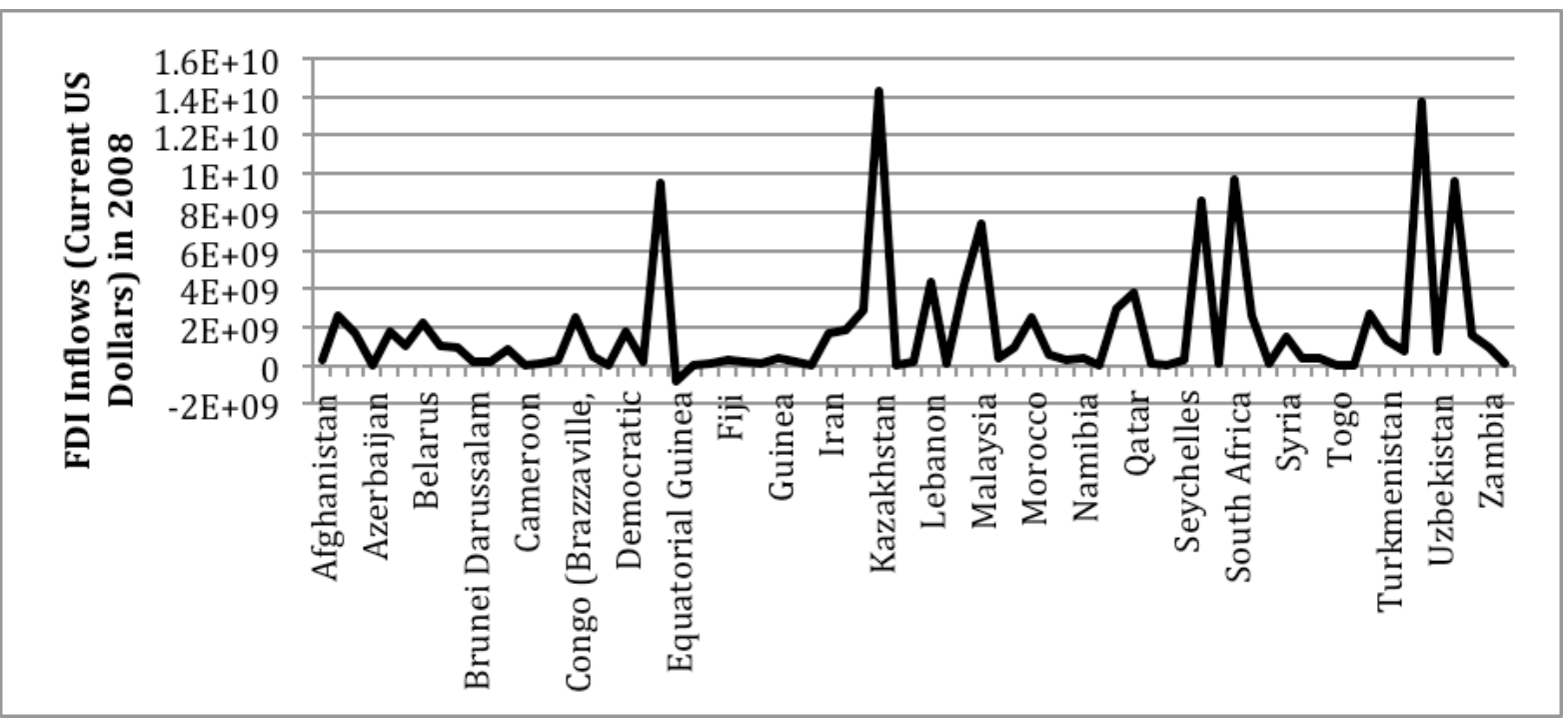

Figure 2 FDI Inflows (Current US Dollars) to Authoritarian Countries in $2008^{6}$

For example, some authoritarian countries, like Egypt, Jordan, Singapore, have been successful in attracting inflows of FDI (9.5 billion, 2.8 billion, and 8.6 billion US dollars respectively), while others, like Cuba, Myanmar, and Zambia, lag behind (with 24 million, 280 million, and 940 million US dollars of FDI inflows respectively).

rights, the police, and the courts, as well as the likelihood of crime and violence” (World Bank 2010).

${ }^{6}$ Please note that I have omitted China, Russia, and Saudi Arabia from this graph to best depict (graphically) the variation in FDI inflows across the greater authoritarian world. In 2008, China, Russia, and Saudi Arabia had inflows of FDI of close to 40, 75, and 175 billion US dollars respectively. 
This raises the question, how do some authoritarian nations lower the perceptions of risk to foreign investors? FDI inflows to democracies is of growing interest to scholars who analyze the role of good governance in attracting investment, yet, little scholarship analyzes how authoritarian regimes reduce foreign investors' perceptions of risk. Drawing on international political economy, international organization, and authoritarian political institution theories, this dissertation seeks to explain the variation of FDI inflows to authoritarian regimes. Thus, the research question addressed in this dissertation is: What explains the variation of FDI inflows to authoritarian regimes?

\subsection{ARGUMENT AND STRUCTURE OF DISSERTATION}

I argue that foreign investors prefer to invest in authoritarian regimes that are constrained from "above” and "below.” The signing of an international investment treaty sends an initial signal to foreign investors of a regime's willingness to promote liberal economic policies. Although participating in these international investment treaties entails financial and reputation costs, there is still a risk of noncompliance by the authoritarian leader. I argue that foreign investors are only assured of stability concerning the economic policies established in the international investment treaties in authoritarian signatories with high levels of citizen participation. Leaders in regimes with little citizen participation pursue rent-seeking policies as they receive little information from the greater populace and have little accountability to citizen preferences. In regimes with high levels of citizen participation, the authoritarian leader pursues welfare enhancing policies as he is informed on and constrained by citizen preferences. This societal feedback provides the authoritarian leader with information on the benefits of FDI as the 
majority of citizens in authoritarian regimes associate FDI with growth and employment. Thus, authoritarian leaders in regimes with high levels of citizen participation will uphold FDI friendly policies. In sum, I hypothesize that authoritarian regimes with investment treaties and high levels of citizen participation will attract the most foreign direct investment as these regimes exhibit long-term commitments to liberal economic policies. Chapters 2 and 3 detail my theory on international and domestic institutions respectively.

This dissertation will use a mixed method research design of statistical regressions and case studies to test my hypothesis and theoretical microfoundations. The purpose of the mixed methods is to ensure that this dissertation identifies both systemic patterns and causal mechanisms. The quantitative methods will produce general knowledge on variation of FDI in authoritarian countries, while the qualitative methods will provide contextual, in-depth knowledge of the concepts, cases, and causal mechanisms.

First, I test my arguments using micro and macro level empirical evidence. Specifically, I conduct multilevel ordered probits of survey data on citizen preferences for FDI (Chapter 4) and statistical regressions of panel data on global FDI inflows (Chapter 5). Survey data highlights how citizens in authoritarian countries find FDI to be desirable. In fact, estimation results indicate that respondents in authoritarian countries associate increased inflows of FDI with increased confidence in government. This finding provides empirical support for the microfoundations of my theory that the public in authoritarian regimes supports FDI inflows.

In addition, I present findings from my original survey of U.S. multinational companies conducted online during January through March 2013. The survey gathers primary evidence on business preferences for foreign investment by asking what national and international institutions secure property right protections and profitable operations for mulitnational companies investing 
in authoritarian regimes. Specifically, I include questions on the role of investment treaties, political institutions and freedoms, business associations, and other non-governmental organizations in ensuring secure and profitable operations. Ultimately, the survey results show that multinational companies are aware of and value international investment treaties and freedom of association in host nations, thereby providing key primary evidence in support of my hypothesis.

In Chapter 5, using cross-national data on FDI inflows to the developing world, I test my hypothesis using statistical regressions on panel data. Estimation results confirm my hypothesis: Authoritarian regimes that sign international investment treaties and have high levels of citizen participation attract the most FDI. Several robustness checks are conducted using alternative specifications of FDI inflows, the independent variables, the sample, and the estimation method. Also, I test and account for endogeneity and alternative hypotheses. All results are robust in supporting my hypothesis.

Last, I conduct an illustrative case study of Jordan and Syria to further understand and develop the theoretical foundations (Chapter 6). The selection of Jordan and Syria is based on the most-similar case research design as Jordan and Syria are both Middle Eastern countries with similar levels of economic development and bilateral investment treaties. Jordan and Syria do differ on one key element: citizen participation. Thus, the case study analysis uses both quantiative and qualitative evidence to uncover how two countries with similar international investment commitments attract FDI inflows. As hypothesized, the constraints on the authoritarian leader play a decisive role in the effectiveness of BITs in attracting foreign direct investment. 


\subsection{SIGNIFICANCE OF DISSERTATION}

The significance of this dissertation is threefold. First, it addresses a gap in the international political economy literature on the variation of FDI inflows to authoritarian countries. Current literature primarily compares democratic and authoritarian countries in their ability to attract FDI inflows without disaggregating the factors within specific regimes that contribute to this phenomenon (Jensen, Bigaliser, Li, Malesky, Pinto, Pinto, and Staats 2012). Democratic and authoritarian countries have unique political environments and risks, so it is important to examine the different mechanisms through which the regimes establish credibility to foreign investors. This dissertation builds on Chandra and Rudra (2011) to analyze the domestic factors that explain the variation of FDI inflows to authoritarian countries.

Second, this dissertation provides theoretical and empirical evidence on how and when international treaties signed by authoritarian countries are credible. In particular, I find that citizen participation plays a key role in ensuring policy stability to international investment treaties in force in authoritarian regimes. As such, this dissertation analyzes compliance from a new and nuanced perspective by focusing on how citizen participation shapes and determines policy stability as opposed to how formal political institutions affect aggregate political risk measures - which are broad, imprecise measures of the constraints on authoritarian leaders and risks involved in investing in authoritarian regimes.

Finally, I present and analyze micro level evidence on citizen and foreign investor preferences concerning foreign direct investment. While research on preferences for trade is abundant, the international political economy literature fails to provide strong empirical evidence or theoretical understanding of preferences for foreign direct investment. In addition, my original survey work on the experiences and preferences of managers in multinational companies takes 
the new approach of incorporating investors as active participants in analyzing the determinants of FDI flows (Jensen, Bigaliser, Li, Malesky, Pinto, Pinto, and Staats 2012). This survey work provides strong primary evidence in support of the microfoundations of my theory. 


\subsection{INTERNATIONAL INSTITUTIONS: THE ROLE OF BILATERAL INVESTMENT TREATIES}

International political economy research highlights how foreign direct investment (FDI) entails the risk of the host government reneging on the agreed terms of business (Vernon 1971). Before investing, multinational companies can negotiate the terms of their investment freely with governments—if the multinational walks away, it does not lose any money or assets. However, after an initial investment is made, multinational companies must account for the costs they have already incurred in future negotiations or disputes. After foreign investors acquire these sunk costs, governments gain bargaining power. Therefore, foreign investors have concerns about host governments who are not reliable to uphold FDI friendly policies.

Because of these sunk costs involved in FDI, foreign investors are averse to political risk. Political risk is defined as government interference in business operations and includes risk to property, contracts, and policy (Kobrin 1979). The greater the chance of political acts, decrees, or policies adversely affecting business operations, then the greater the political risk of the host. Politically risky countries have higher probabilities of contract violations, expropriations or nationalizations, and other ex-post policy changes by the government (Jensen, Malesky, and Weymouth 2012: 2). As a result, high levels of political risk can result in a loss of profit for multinational companies. Low risk is critical to foreign investors because they want to protect 
their assets from expropriation and prevent contract violations and ex-post policy changes by the government.

Research shows that developing democracies attract more FDI than authoritarian countries because their strong governance infrastructure reduces opportunistic behavior by the government (Daude and Stein 2007, Jensen 2003, Globerman and Shapiro 2002, Jensen, Biglaiser, Li, Malesky, Pinto, Pinto, and Staats 2012) ${ }^{7}$. Specifically, democracies have less political risk than authoritarian regimes because of their governance institutions and strong property rights protections (Jensen 2003, Jensen 2008). Democratic institutions “collectively serve to strengthen the rule of law and secure private property rights” (Li 2006: 64). Thus, secure property rights are most often found in democracies $(\mathrm{Li} \mathrm{2006})^{8}$. As a result, scholars argue that investors should be attracted to democratic regimes over authoritarian regimes because of the security and credibility of democratic institutions ${ }^{9}$.

${ }^{7}$ Oneal (1994) is the first article to use quantitative evidence to explore the relationship between regime type and foreign direct investment. He finds an insignificant relationship between regime type and FDI inflows, although profits for multinational companies are higher in authoritarian regimes.

${ }^{8}$ Data from the World Bank's (2010) World Governance Indicators verifies that the rule of law in authoritarian regimes is consistently lower than the rule of law in democracies. Overall, the average rule of law, in developing democracies is -0.01 , while it is -0.70 in authoritarian countries. (WGI scales the rule of law from -2.5 to 2.5 , with higher values indicating a stronger rule of law.) Additionally, the rule of law in authoritarian countries is stagnant over time. In over ten years, the average rule of law in authoritarian countries remains consistently around -0.70 , revealing little improvement in protecting property rights over time. See Figure 21 in Appendix A.

${ }^{9}$ It is important to note that even the literature highlighting how authoritarian regimes can be attractive for FDI, concedes that democracies' strong property rights protection is attractive for foreign investors. For instance, only after controlling for property right protection are democracies associated with a reduction in FDI (Li and Resnick 2003). Therefore, protection of property rights is a great priority for foreign investors. 


\subsection{THE EFFECTIVENESS OF INTERNATIONAL INSTITUTIONS}

However, there is evidence that authoritarian regimes may be able to reduce their political risk. International agreements provide contractual frameworks supporting liberal economic policies, thus providing foreign investors some assurance of a commitment to these policies (Buthe and Milner 2008, Fang and Owen 2011, UNCTAD 2007). The dissemination by and transparency of information in international institutions facilitates the identification, monitoring, and punishment of those not complying with the rules or contracts (Buthe and Milner 2008, Mansfield, Milner, and Rosendorff 2002, Mansfield and Reinhardt 2008). Further, signing an international agreement subjects the signatory nation to an international audience (Fearon 1997). States, multinational businesses, and international institutions monitor the signatory nation's compliance to the international agreement in order to develop accurate expectations as to the signatory's commitment to liberal economic policies and respect for international agreements. Noncompliance to international agreements has international reputational and financial effects as these international actors, upon learning of contract violations, can create negative publicity about the signatory, reduce their future investment into the signatory, or demand financial or legal retribution (Allee and Peinhardt 2011, Fang and Owen 2011).

In particular, bilateral investment treaties (BITs) establish the terms for foreign direct investment (Hallward-Driemeier 2003, Rosendorff and Shin 2011). BITs involve direct negotiations between countries on dispute resolution mechanisms, compensation for expropriation, and investment entrance and profitability (Elkins, Guzman, and Simmons 2006, Hallward-Driemeier 2003, Neumayer and Spess 2005). Dispute resolution provisions vary across BITs, especially in the specification of international or domestic courts for arbitrations; however, 
international arbitration centers like the International Center for the Settlement of Investment Disputes (ICSID) or the International Chamber of Commerce in Paris are included in the majority of BITs globally. BITs also provide transparency on the rights of the foreign investor. For example, the United Nations Conference on Trade and Development (UNCTAD) (2007) explains that "Most BITs include the standard of fair and equitable treatment" (xii), in addition to clauses on the transfer of funds, the entry of foreign nationals, and protection during war or civil disturbances. Overall, BITs are intended to secure foreign investors' assets through agreeing on the rights and treatment of investors and setting up terms for compensation and conflict resolution (UNCTAD 2007).

Although there is conflicting research on the effectiveness of BITs, overall, strong support for BITs attracting FDI exists (see Allee and Peinhardt 2011 for similar discussion). For example, some scholars provide evidence that BITs do not influence inflows of FDI (Yackee 2007). However, several authors attribute the conflicting conclusions to different sample sizes and empirical methods used in each study. In particular, much of the literature only accounts for FDI outflows from developed countries (Aisbett 2007, Desbordes and Vicard 2009, HallwardDriemeier 2003, Kerner 2009, Salacuse and Sullivan 2005, Tobin and Rose-Ackerman 2011). This sample greatly reduces the number of observations. Furthermore, several studies, such as Hallward-Driemeier (2003), use dyadic data. Neumayer and Spess (2005) explain that the use of the dyadic data limits the sample size and ignores the signaling effect or spillover effects of BITs in attracting investment. After running their panel model of 120 countries from 1970 to 2001, they find that BITs do attract FDI. Buthe and Milner (2009) confirm this positive relationship between BITs and inflows of FDI with a dataset of 122 developing counties over 31 years. Furthermore, in regards to authoritarian countries, Rosendorff and Shin (2011) provide evidence 
that BITs are especially effective in attracting FDI inflows to authoritarian countries (compared to democratic developing countries).

\subsection{ARGUMENT: BILATERAL INVESTMENT TREATIES AS A \\ CREDIBLE SIGNAL}

I argue that signing a BIT plays a critical role in credibly signaling to foreign investors that the signatory countries are dedicated to promoting and protecting liberal economic policies (Neumayer and Spess 2005, Kerner 2009). BITs provide all foreign investors access to information on national policies relating to investment and property rights. As international agreements, BITs are highly visible and accessible contracts — texts are available on the United Nations Conference on Trade and Development's website and many nations publicize BIT signings in the national media (Buthe and Milner 2009: 184). Signing a BIT signals economic openness and friendliness to foreign investors ${ }^{10}$.

This signal of a host country's FDI friendly policies is especially important for authoritarian regimes. Generally, authoritarian regimes are considered non-transparent (Rosendorff and Shin 2011), so the BIT plays a vital role in communicating host country investment policies to foreign investors. The international agreement provides transparency on the rights of the foreign investor and liberal economic policies of the host.

10 The strength of this signal increases as countries sign treaties with many signatories because of the increase in the visibility (and information flows) of the dedication to FDI friendly policies. Allee and Peinhardt (2011) explain, "Governments that sign multiple treaties may be able to send a more effective signal, and this accumulation of numerous treaties demonstrates a stronger general commitment to protect investment and to promote a healthy investment climate for all foreign investors” (404). 
Signing a BIT also signals a dedication to pursuing liberal economic policies to a domestic audience. Mansfield, Milner, and Rosendorff (2002) explain that signing an international treaty sends a signal to domestic audiences of the government's policy decisions. In the case of a negative shock (ie, a decline in a country's economic performance), this domestic signal is critical in assuring citizens that the government was/is pursuing strong economic policies.

Signing a BIT is a credible signal as it is not a costless venture- there are financial and reputation costs associated with noncompliance to a $\mathrm{BIT}^{11}$. Violating the terms of a bilateral investment treaty is associated with financial costs if violators are taken to court (thereby involving court fees) and if financial damages are then demanded. Foreign investors do use the mechanisms established within the BITs to secure their rights and ensure proper compensation for contract violations as one hundred fifty-six investor-state disputes have entered the ICSID (Alle and Peinhardt 2010). One example case is when the ICSID awarded Desert Line Projects, LLC monetary compensation for a breach of contract by the Republic of Yemen in 2008 (Desert Line Projects, LLC v. Republic of Yemen 2008). Desert Line Projects, LLC entered into a contract with the Yemeni government to build roads. However, after the majority of construction was completed, the Yemeni government failed to make payments for services rendered. In response, Desert Line Projects, LLC brought claims of a BIT violation to the ICSID. Subsequently, the ICSID ruled in favor of Desert Line Projects, LLC.

${ }^{11}$ In addition, Kerner (2009) discusses the ex-ante costs associated with signing a bilateral investment treaty. Signing BITs affects (1) the creation and implementation of domestic laws and (2) the treatment, protections, and competition of domestic and preexisting foreign investors (Kerner 2009: 79-80). 
Additionally, as discussed previously, violating an international agreement is also associated with reputational effects. In regards to violating a BIT, Alle and Peinhardt (2011) test the reputational effect of the ICSID and find a loss in inflow of FDI associated with nations taken to the ICSID. Thus, government actions and policy decisions after signing a BIT can affect future inflows of FDI. Ronald Lauder's experience investing in the Czech Republic exemplifies the reputational effects of signing and subsequently violating a BIT. Although protected under the Czech Republic-U.S. BIT, Lauder's Central European Media Enterprise’s (CME) contract was violated by Vladimir Zelezny’s Czech Media Council (see Kerner 2009, Franck 2005 for details). After the contract was broken, Lauder publically denounced investing in the Czech Republic in the NY Times, Washington Post, and a Congressional Senate Hearing (Kerner 2009, Franck 2005, U.S. Congress 2000).

\subsection{RISK OF NONCOMPLIANCE}

However, BITs alone are not effective in attracting the most foreign direct investment inflows to authoritarian countries because of a continued risk of noncompliance. I argue that the aforementioned international financial and reputational costs are insufficient to ensure a credible commitment by authoritarian governments. ${ }^{12}$ This risk of noncompliance is associated with the weak governance institutions within certain signatory authoritarian nations-the domestic

${ }^{12}$ My argument contrasts sharply with Rosendorff and Shin (2011) who indicate that authoritarian countries import stronger governance institutions when signing a BIT, thereby attracting FDI to that host country. Rosendorff and Shin (2011) fail to account for compliance to BITs signed by authoritarian governments. Other scholars, such as Tobin and Rose Ackerman (2011), explain that the effectiveness of BITs in attracting FDI inflows depends on the strength of domestic institutions of the signatory. 
constraints on the authoritarian leader play an important role in the effectiveness of the BIT in attracting $\mathrm{FDI}^{13}$. All authoritarian leaders do not necessarily sign international agreements with the intention to comply (Vreeland 2008). BITs have financial and reputational costs (Allee and Peinhardt 2011) but this does not necessarily threaten the authoritarian leader’s power.

Assuming he is a rational actor, the authoritarian leader will weigh the costs of noncompliance with the benefits of noncompliance. If violating the BIT results in a lucrative product, beyond the international reputational and financial costs, he will choose to violate. Underdal (1998) explains that a party will comply with an international agreement "If, and only as long as, expected marginal abatement costs minus any implementation benefits are lower than expected marginal damage costs plus any sanction costs incurred by defecting” (9). An authoritarian leader can gain power and resources from expropriation and other violations of the

${ }^{13}$ Weak legal provisions within certain BITs signed by authoritarian governments could also increase the risk of noncompliance. BITs signed by some authoritarian countries have weak legal provisions, so there is not necessarily an international court to uphold the terms of the agreement. Allee and Peinhardt (2010) find evidence that signatories do not insist upon the International Centre for the Settlement of Investment Disputes in their BITs with countries that "have poor legal institutions or unstable political systems. In other words, international arbitration through ICSID is not a substitute for poor domestic institutions” (3). Without access to the ICSID in these nations, investors face high transaction costs and uncertain domestic legal environments. Data from Allee and Peinhardt (2010) indicates that the strength of enforcement procedures is realtively weak in BITs signed by authoritarian governments. They have an average strength of enforcement provisions score of 1.4 out of 3 (compared to an average of 1.7 in BITs signed by two democracies). Twenty percent of the time, BITs signed by authoritarian regimes do not use the ICSID, while democracies use the ICSID close to 95 percent of the time. BITs signed by authoritarian regimes do not necessarily contain the strong legal provisions with international courts that would ensure a credible commitment. However, the overwhelming majority of BITs signed by authoritarian countries do include international courts for arbitration (eighty percent specify the ICSID), so it is predicted that the strength of enforcement procedures specified by the bilateral investment is not illustrative in predicting compliance to BIT provisions. The lack of variation in dictating the ICSID as the arbitration court reduces its power in predicting FDI inflows. In addition, the arbitration procedures specified in the BIT does not address domestic factors that affect an authoritarian leader's compliance to the rule of law. Empirical results confirm the ineffectiveness of strength of enforcement procedures in attracting FDI to authoritarian countries with BITs in force. See Table 26 in Appendix C. 
treaty (Li 2009a). Olson (1993) further verifies that authoritarian rulers "have an incentive to extract the maximum possible surplus from the whole society and to use it for his own purposes" (569). Thus, it is expected that noncompliance will be relatively higher in authoritarian countries. Empirical research verifies that authoritarian countries do comply less with international agreements than democratic countries (Mansfield, Milner, and Rosendorff 2002, Dai 2005). In general, without the institutional constraints found in democracies, authoritarian governments have trouble 'tying their own hands' (Haber et al 2003, Olson 1993, North 1990). Thus, signing an international agreement with an authoritarian regime entails a high risk of noncompliance. This risk of noncompliance reduces the reliability of the BIT commitment.

Foreign investors prefer to invest in countries that are reliable in upholding international contracts (Allee and Peinhardt 2011). Even if foreign investors are eventually compensated for BIT violations through court proceedings, they are averse to investing in countries with high levels of noncompliance as this noncompliance can be associated with disruptions to business and profit, short-run financial losses, and lengthy legal proceedings (See ICSID case decisions that describe claimants' allegations and injuries). For example, in Lauder's case against the Czech government described earlier, CME sought 527 million dollars in damages and 200 million dollars in interest and other penalties, while the international arbitration panel awarded CME only 353 million dollars from the Czech government (Green 2003).

Ultimately, the international political economy research fails to address when authoritarian regimes are reliable in upholding international investment agreements. Bilateral investment treaties are critical in initially attracting foreign investors, but they are not sufficient to attract the highest levels of FDI to authoritarian regimes. This dissertation uncovers how institutional variation within authoritarian regimes affects the credibility of BITs in attracting 
foreign direct investment. Specifically, I build on Chandra and Rudra (2011) to look beyond formal, power institutions within authoritarian regimes and examine the role of societal feedback in constraining a dictator's ability to make erratic, opportunistic decisions on investment policies. 


\subsection{DOMESTIC INSTITUTIONS: THE ROLE OF CITIZEN PARTICIPATION}

Scholarly work shows that the effectiveness of bilateral investment treaties in attracting FDI inflows depends on the domestic institutional environment of the host government (Desbordes and Vicard 2009, Hallward-Driemeier 2003, Tobin and Rose-Ackerman 2011). As Tobin and Rose-Ackerman (2011) explain, "BITs may be touted as a way to avoid the risks of local legal and political institutions, but ... their main role for developing countries is to lend credibility to an otherwise favorable domestic environment” (6). Regimes with weak domestic institutions cannot reduce all political risk by signing a BIT.

Authoritarian leaders without institutional constraints are likely to pursue rent-seeking policies, like expropriations, that threaten a foreign investor's assets and security (Li 2009a, North and Weingast 1989, Weymouth 2011). These leaders pursue policies in their own selfinterest as they have little accountability to (or knowledge of) public preferences. Expropriation or nationalization can benefit the leader by providing him immediate access to resources or revenue ( $\mathrm{Li}$ 2009a). Therefore, there is a great risk of violations of the BIT property right policies in these regimes.

Regimes with constraints on authoritarian leaders exhibit less volatile, opportunistic decision-making (Tseblis 1995, Chandra and Rudra 2011). Traditionally, institutional constraints associated with policy stability were measured through formal institutions of power, or veto players (Tseblis 1995, Henisz 2004). A regime with many veto players needs many actors to 
agree and compromise for a policy change. So, policy stability is associated with a greater number of veto players.

Yet, formal political institutions in authoritarian regimes do not effectively reduce radical policymaking by authoritarian leaders; the legislature and political parties are exclusive, nonbinding, and intended for cooptation (Chandra and Rudra 2011, Wright 2008, Magaloni $2008)^{14}$. For example, Wright (2008) and Lust-Okar (2005) describe the legislature as a forum to reward and challenge opposition groups throughout the authoritarian world, such as in the Dominican Republic, Malawi, Morocco, and Jordan. Instead of constraining the authoritarian leaders, the legislature was used by the leader to further advance and secure power. Current research shows that formal political institutions do not effectively constrain authoritarian leaders: Jensen, Malesky, and Weymouth (2012) find an insignificant relationship between the presence of a competitive legislature and expropriation risk. Their results indicate that foreign investors do not view the presence of a competitive legislature as effective in reducing the risk of expropriation. Investors are not assured that their assets will be protected when an authoritarian regime has a legislature or political parties as these formal institutions are not associated with stability in authoritarian regimes (Mishler and Hildreth 1984).

${ }^{14}$ Classical authoritarian institutional research further discusses the inability of formal political institutions to constrain authoritarian leaders (see for example, Friedrich and Brzeinski 1961). 


\subsection{ARGUMENT: CITIZEN PARTICIPATION AS A CONSTRAINT ON AUTHORITARIAN LEADERS}

Instead, building on Chandra and Rudra (2011), I argue that authoritarian regimes with higher levels of informal, unconstrained citizen participation in decision-making are associated with greater policy stability ${ }^{15}$. Chandra and Rudra (2011) explain that citizen participation in the policymaking process increases the information available to the head of government as partisans (political leaders, citizens, associations, administrators, technocrats, etc.) negotiate and compromise. As the authoritarian leader learns of the policy consequences, he will adopt "safe, incremental policy proposals" (Chandra and Rudra 2011: 3). Although citizen participation is more advanced in democracies, some authoritarian regimes exhibit relatively high levels of citizen participation (Chandra and Rudra 2011, Leib and He 2006, Dryzdek 2009). In these authoritarian regimes, societal feedback provides a constraint on an authoritarian leader's myopic

${ }^{15}$ Most classifications of authoritarian regimes rely on formal political institutions (Levitsky and Way 2002, Diamond 2002, Magaloni 2008, Gandhi 2008) or executive power structures (Geddes 2003, Hadenius and Teorell 2007). Diamond (2002) explains the reliance on formal institutions in classifying authoritarian regimes: "While contestation in the judiciary and the mass media is hard to quantify, contestation in elections and legislatures does allow for more structured comparison” (29). Despite the quantifiable merits of classifying regimes by formal political institutions, the data increasingly shows little variation in these institutions over time. This is confirmed by Diamond (2002): Virtually all hybrid regimes in the world today are quite deliberately pseudodemocratic, 'in that the existence of formally democratic political institutions, such as multiparty electoral competition, masks (often, in part, to legitimate) the reality of authoritarian domination'” (24). Additionally, formal political structures do not capture other constraints on the dictator, like civic organization and participation. Howard and Roessler (2006) explain how in authoritarian countries, "Widespread public mobilization can also play a crucial role in the opposition's ability to challenge the incumbent," (372). The ability of citizens to mobilize captures the representativeness and inclusiveness of a regime, thereby measuring constraints on authoritarian leaders' decision-making. 
and radical behavior ${ }^{16}$. Authoritarian leaders are sensitive to this information because they want to thwart rebellion and maintain stability (Gandhi and Przeworski 2006, Romero 2004, Chandra and Rudra 2011). As these leaders learn from and listen to the information provided by their constituents, they derive support through their participatory law making and welfare enhancing policies (as opposed to maintaining power by coercion) ${ }^{17}$.

In authoritarian regimes with citizen participation, citizens can and do organize for economic purposes and issues ${ }^{18}$. Citizen economic groups include business and labor

${ }^{16}$ Chandra and Rudra's (2011) theory provides a distinct hypothesis from veto player theory. According to their theory, regimes with few veto players, but high levels of citizen participation, exhibit incremental policymaking. This result is opposite from what veto player theory would predict. Chandra and Rudra (2011) describe how their theory differs from veto player theory in two ways: "The veto player model emphasizes the veto power vested in formally designed political actors, while we ascribe importance to the ability of partisans to negotiate directly and indirectly (and formally and informally)... In the veto players literature, power (and specifically veto power) is the key driver of outcomes. By contrast, we emphasize the value of information" (fn 15).

${ }^{17}$ In order to stay in power, authoritarian leaders can either repress or provide concessions (such as allowing citizen participation in policymaking) (Gandhi and Przeworski 2007). For example, Linz (2000) describes two types of dictatorships, "totalitarian" and "authoritarian" regimes. "Totalitarian" regimes rely on massive coercion to maintain power. All political participation and civil society organization are channeled and controlled by the central government. However, in "authoritarian" regimes, according to Linz (2000), leaders allow limited pluralism. State and society have some separation and thus certain interest groups are allowed to organize. These leaders remain in power by appeasing and maintaining the support of the organized coalitions. Ultimately, authoritarian leaders choose different survival methods based on their revenue sources and availability and the strength, size and institutionalization of their supporters and the opposition (Desai, Olofsgard, and Yousef 2009, Bueno de Mesquita and Smith 2010, Conrad 2011). Although the different survival tactics (coercion, concessions) are not mutually exclusive, Linz (2000) highlights how certain regimes rely on coercive (or non-coercive) tactics more than the others.

${ }^{18}$ Citizen participation on economic issues and organization of economic groups allows for some citizen power, but it is less threatening than citizen mobilization for political purposes or organizations. For instance, in China, "The CCP has adopted inclusive policies toward members of non-critical realm, particularly private entrepreneurs and technical specialists, while continuing to exclude and repress those from the critical realm who push for democratization and liberalizing reforms” (Dickson 2003: 22). Inclusion of economic groups allows for an economic dialogue without the greater threat of a political dialogue. 
associations and local community organizations, like homeowner associations ${ }^{19}$. For example, the business association literature highlights group mobilization for economic issues in Uganda, Nigeria, Pakistan, Egypt, Russia, China, and Morocco (Khadiagala 2001, Lucas 1997, Pyle 2006, Bianchi 1985, Kennedy 2009, Cammett 2005). Economic groups in these countries have successfully mobilized to protect property rights, endorse liberalization, and collaborate on business ventures (Khadiagala 2001, Lucas 1997, Pyle 2006, Bianchi 1985). Evidence from the World Bank's Business Environment and Enterprise Survey (2005) in Eastern Europe and Central Asia confirms this notion. In this survey, respondents in authoritarian countries find business associations of major and critical value (highest values on a five point scale) to lobbying the government and accessing critical information on domestic markets and government regulations. The organization and activities of these economic groups facilitates a critical exchange of information between the government and the greater community on economic policies and conditions (Schneider and Maxfield 1997) ${ }^{20}$.

In addition to organizational activities, citizens in authoritarian countries are actively involved in economic policy through surveys, polls, conferences, forums, and workshops (Gao

${ }^{19}$ Examples in China include the private business association, Self Employed Laborers Association (Nevitt 1996), and the homeowner association, Property Owners' Committee (Ogden 2002). Interestingly, Dickson (2003) found that in China "A clear majority—almost 70 percent—of private entrepreneurs believes business associations can influence policy” (160). ${ }^{20}$ Business associations conduct market supporting and market complementing activities across the developing world (Doner and Schneider 2000). Market supporting activities occur when "Associations push underperforming states to provide the public goods only states can provide: property rights, uncorrupt administration, and infrastructure” (Doner and Schneider 2000: 262). Market complementing activities include "Functions that overcome market failures of various sorts including imperfect and costly information, low investment in training, and the lack of coordination in investments" (Doner and Schneider 2000: 262). Business associations increase accountability, transparency, and information flows (Lucas 1997, Zhang 2007, Nugent et al 2009, Maxfield and Schneider 1997, Moore 2001). 
2012, Leib and He 2006, Ogden 2002, Romero 2004) ${ }^{21}$. A great example of citizen participation on economic issues in authoritarian regimes is participatory budgeting. Participatory budgeting practices have been increasing across the world, even in authoritarian regimes (Pateman 2012, Sintomer et al 2010, Shah 2007). Participatory budgeting involves citizens and elected officials meeting and discussing resource constraints and allocations, including investment decisions (Shah 2007, Sintomer et al 2010). Originating in Latin America, participatory budgeting exists throughout the world and in authoritarian countries like Zimbabwe, Egypt, Tanzania, Cameroon, Armenia, China, and Russia (Shah 2007, Sintomer et al 2010).

Chandra and Rudra (2011) explain that not all partisans may have access to and influence on political deliberation (15). However, I argue that in regards to policies relating to foreign direct investment, authoritarian leaders have an incentive to incorporate and listen to the wider populous. As these leaders remain in power through non-coercive tactics, they rely on achieving growth and employment enhancing policies to maintain public support. Thus, information flows from the public are critical to ensuring the leader can advance policies that will benefit the greater economy and populace. Domestic firms (competing with foreign firms) will be active in the political discussion, yet their protectionist preferences will not dominate as the leader has an incentive to pursue employment-enhancing policies. Another alternative hypothesis is that under conditions of civic freedom and deliberation the strength of labor groups will deter foreign investment. However, even in authoritarian regimes with high levels of citizen participation, labor rights remain low. For example, in authoritarian regimes with high levels of citizen

${ }^{21}$ For instance, in 1987, Russia founded the All-Union Center for Public Opinion Research on Socio-Economic Issues (VCIOM), which still regularly conducts surveys and research programs on citizen's socioeconomic status, attitudes, and preferences. Although some authoritarian regimes restrict or manipulate public opinion research, many regimes do use and allow polling (Romero 2004). 
participation, workers' rights remain severely restricted with an average score of less than $1(0.8)$ on the Cingranelli-Richards (CIRI) Human Rights Dataset's workers' rights scale of 0 (severely restricted) to 2 (fully protected). Further, Kim and Gandhi (2010) find that institutionalized authoritarian regimes co-opt labor in exchange for peaceful relations. Thus, disruptions to businesses due to strikes and protests will be minimal in many authoritarian regimes that allow forums for citizen organization and deliberation.

\subsection{SOCIETAL FEEDBACK ON BENEFITS OF FDI}

I argue that as citizens and organizations in authoritarian regimes provide feedback on economic issues, the majority will support property rights protections and inflows of FDI. Citizens in authoritarian regimes view FDI as welfare enhancing as it is associated with upward mobility, economic growth, and favorable labor conditions (Linardi and Rudra 2012, Tseng and Zebregs 2002, Hanson and Rand 2006, Scheve and Slaughter 2004, TeVelde and Morrissey 2004). The international political economy literature confirms that multinational companies provide their workers better wages, working conditions, and rights (Mosley and Uno 2007, Mosley 2011, Gorg, Strobl, and Walsh 2007, Aitken, Harrison, and Lipsey 1996). Accordingly, a critical component of my theory is that citizens in authoritarian countries find FDI inflows to be desirable.

Ultimately, authoritarian leaders receiving high levels information from partisans on foreign direct investment on will exhibit greater policy stability on FDI friendly policies as these leaders are informed of the benefits of FDI. In fact, Frye (2004) provides evidence that under conditions of civic participation in an authoritarian regime, business associations and other social 
groups lobby the state to secure property right protections. Additionally, overall, the flow of information provides the authoritarian leader feedback on FDI policy preferences and consequences, leading to greater bargaining and compromise, and thereby reducing radical and volatile decision-making.

\subsection{FOREIGN INVESTORS AND CITIZEN PARTICIPATION}

I argue that foreign investors are attracted to these authoritarian regimes with high levels of citizen participation as this environment is associated with domestic policy stability. Research confirms that foreign investors prefer stable investment environments (Asiedu 2006, Busse and Hefeker 2007, Schneider and Frey 1985), as policy stability is associated with stronger property right protections and predictable economic policies (Weymouth 2011, Henisz 2004, Chandra and Rudra 2011).

Foreign investors recognize and value the ability to organize and provide government leaders with policy information as MNCs themselves work and partner with local organizations that support liberal economic policies. For example, across the developing world, foreign investors participate in local business organizations and have foreign-based associations and institutions, like Chambers of Commerce (Egan 2010, World Bank 2005). Egan (2010) succinctly describes the roles and interactions between local and foreign organizations and investors in Latin America:

A number of organizations act on behalf of multinationals in Latin America, providing an interface with policymakers. Chambers of commerce may lobby for changes in tax codes; industrial associations can identify barriers to smooth and efficient operations. Even individual connections between high-ranking bureaucrats and heads of multinational firms can provide conduits for policy pressure (10). 
Regimes permitting citizen participation provide foreign investors greater opportunity to work with local civil society to advance and ensure policies advantageous to foreign investment and property right protection. Thus, a second critical component of my theory is that foreign investors are aware of and actively engaging with civil society in authoritarian countries.

Policy stability is especially valuable to foreign investors investing in authoritarian regimes with BITs because investors want to ensure the FDI friendly policies in the BIT contract will be upheld over time. Stability to the BIT liberal economic policies attracts greater inflows of FDI as foreign investors in this environment feel secure that the policies protecting their investment will remain in place. Thus, the effectiveness of a BIT attracting FDI will increase in authoritarian regimes with policy stability.

An alternative hypothesis would be that regimes with high levels of corruption would allow firms to swiftly gain access to government officials and influence over policymaking (Egger and Winner 2005), thus reducing the benefits of civil society organizations and networks. However, the vast majority of the international political economy evidence indicates that foreign investors are attracted to regimes with low levels of corruption (Benassy Quere et al 2007, Busse et al 2007, Habib et al 2002, Mathur and Singh 2013, Smarzynska and Wei 2000). Egger and Winner (2005) is the only article showing corruption attracts FDI inflows. However, upon close examination of their results, regions with many authoritarian countries (Asia, Africa) show a negative relationship between corruption and FDI inflows, while regions with few authoritarian countries (South America, Europe) exhibit a positive relationship (Egger and Winner 2005: 948). Therefore, corruption may be attractive to foreign investors only after a strong governance infrastructure exits because, in this situation, corruption greases the bureaucratic system. Yet, in 
countries with weak laws, corruption further contributes to the uncertainty of contract and property right protections.

\subsection{HYPOTHESIS}

Ultimately, I argue that foreign investors prefer to invest in regimes with stable, FDI friendly policies. A bilateral investment treaty sends an initial signal to the foreign investor that the signatory is dedicated to pursuing liberal economic policies. Foreign investors are then further assured of a long-term commitment to the BIT in regimes with citizen participation. Thus, my hypothesis is:

Hypothesis: Authoritarian regimes with bilateral investment treaties and high levels of citizen participation will attract the most FDI, while authoritarian regimes with either no bilateral investment treaties or low levels of citizen participation will attract less (or no) FDI. 


\subsection{MICROFOUNDATIONS: CITIZEN AND BUSINESS PREFERENCES FOR FDI}

Using survey data, I explore and assess the theoretical microfoundations of my argument that citizens in authoritarian countries want inflows of FDI and that multinational companies value bilateral investment treaties and citizen participation when investing in authoritarian countries. Analyzing survey evidence is critical to understanding and directly measuring preferences for foreign direct investment- an issue understudied in international political economy research. Ultimately, this chapter provides strong micro-level evidence in support of the tenants of my theory.

\subsection{SURVEY EVIDENCE ON CITIZEN PREFERENCES}

First, I evaluate citizen support for foreign investment in authoritarian countries using survey data from the PEW Global Attitudes Project (2003 and 2007) and the Asia Europe Survey (ASES) (2001). The PEW Global Attitudes Project contains survey data for 52 developing countries across the world. The ASES survey provides data for survey respondents in seven developing Asian nations. Specifically, the PEW survey question is, "Is the influence of large companies from other countries very good, somewhat good, somewhat bad or very bad in (survey country)?” The response ranges from one to four: very bad to very good, respectively. The ASES question is, "Could you tell me how much confidence you have in International Big 
Business?” This question is coded from one to four: none at all, not much, quite a lot, and great deal, respectively. Table 28 in Appendix D lists the countries sampled in this survey.

It is expected that citizens in authoritarian countries find FDI desirable as it is associated with economic growth and favorable labor conditions, thus a majority of respondents should indicate high confidence in international big business and a good influence of foreign companies. Figure 3 below provides support for this hypothesis that citizens in authoritarian regimes find FDI desirable.

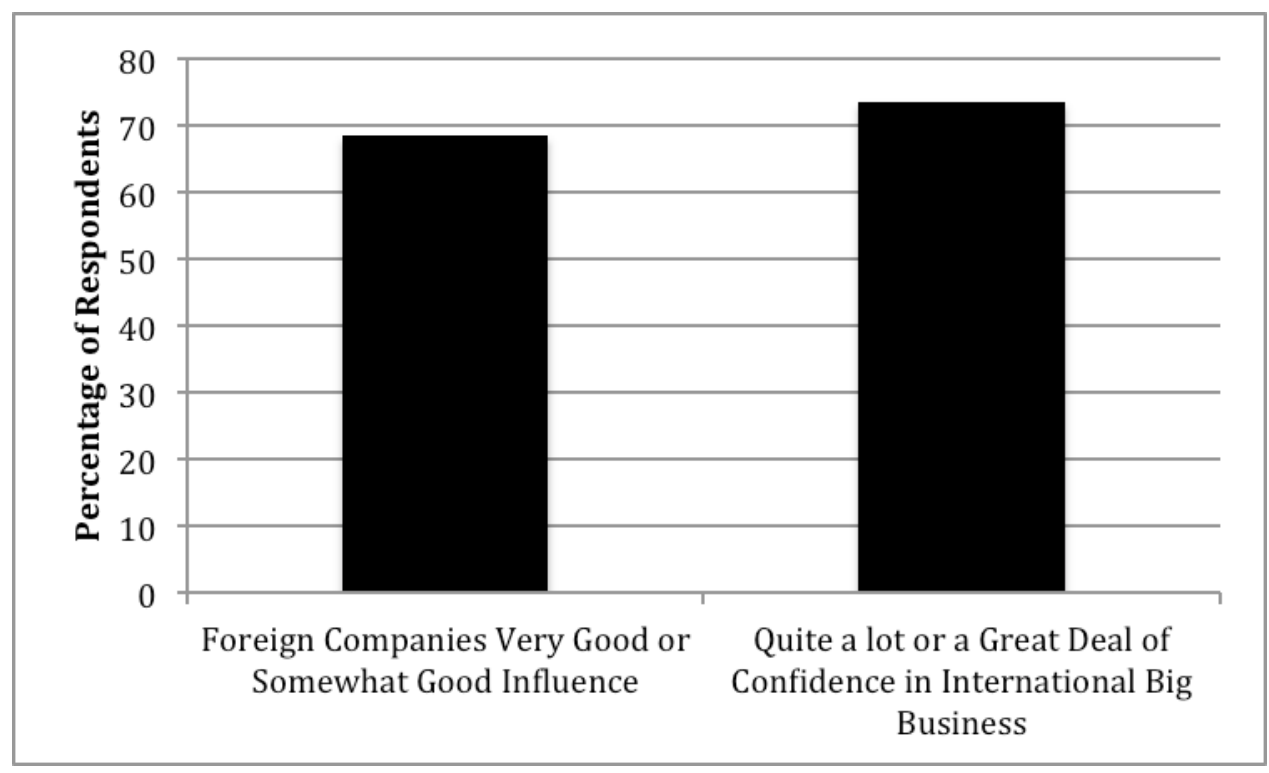

Figure 3 Citizen Preferences for FDI in Authoritarian Countries

The overwhelming majority of survey respondents living in authoritarian countries selected that foreign companies are a good influence (68 percent) and that they have a lot of confidence in international big business (74 percent). Interestingly, the support for FDI by citizens in authoritarian regimes is higher than their counterparts in democratic countries (65 percent and 59 percent support by citizens living in democracies in the PEW and ASES respectively).

Next, I analyze the impact of FDI inflows on confidence in government in authoritarian countries. I theorize that citizens in authoritarian regimes find FDI to be desirable and therefore 
want the government to uphold property right protections and contracts for foreign investors. I predict that citizens in authoritarian regimes associate greater inflows of FDI with greater confidence in government because greater inflows of FDI are related to greater capacity by the government in attracting foreign investment and protecting private property rights.

The dependent variable, confidence in government, is collected from the World Values Survey Wave Four (2000) for 16 authoritarian countries (see Table 28 in Appendix D for list of countries in the sample). The specific survey question is "Could you tell me how much confidence you have in the government: is it a great deal of confidence, quite a lot of confidence, not very much confidence or none at all?” The responses are coded from one to four: none at all to a great deal, respectively.

The independent variable of interest is inflows of FDI. This variable measures the total inflows of foreign direct investment as a percent of GDP (World Bank 2011). It is expected that citizens in authoritarian countries associate inflows of FDI with greater government confidence, thus the coefficient on the democracy variable should be negative and statistically significant.

I test my hypothesis using a multilevel, ordered probit with key controls at the individual and country level. At the individual level, I account for the respondent's gender, education, and income (WVS 2000). At the country level, I control for GDP growth and life expectancy to capture economic success and level of development (World Bank 2011). To account for reporting bias, I include an objective measure. Rule of law is associated (objectively) with government confidence and therefore it serves as the objective measure (Kenyon and Naoi 2010, World Bank 2010). Thus, I estimate my model including this objective measure that is highly correlated with the subjective survey response to address potential reporting bias. The variable descriptions are in Appendix D, Table 29. 
Table 1 Effect of FDI Inflows on Government Confidence in Authoritarian Countries: Multilevel

\section{Ordered Probit}

Base Model

Full Model

Government Confidence

Government Confidence

Objective Measure

$0.293^{* * *}$

(0.015)

$-0.088 * * *$

Individual Level Indicators

Male

$-0.026 *$

(0.020)

Education

(0.014)

$-0.056 * * *$

(0.003)

$-0.029 *$

(0.015)

$-0.040 * * *$

(0.003)

Income

$-0.046 * * *$

(0.004)

Country Level Indicators

Inflows of FDI

$0.128 * * *$

$0.103 * * *$

(0.003)

(0.004)

GDP Growth

$0.093 * * *$

(0.003)

Life Expectancy

$-0.011 * * *$

(0.001)

Observations Level 1

Observations Level 2

24472

16

21543

Random Variance Level 1

0.146

16

Model Deviance AIC

60891.87

0.144

Model Deviance BIC

60956.72

Robust standard errors in parentheses

${ }^{* * *} \mathrm{p}<0.01,{ }^{* *} \mathrm{p}<0.05,{ }^{*} \mathrm{p}<0.1$

52984.16

53071.92

Table 1 provides robust support for my hypothesis. Inflows of FDI are positively and significantly associated with confidence in government for citizens in authoritarian countries. GDP growth is also associated with increased government confidence (this is corroborated in the literature, see Chappell (1990) for example). However, as citizens become more educated or wealthy, they have less confidence in government (see Cook and Gronke (2005) for similar 
education results and Espinal et al (2005) for a discussion and empirical evidence on middle income citizens having less confidence in government than low income citizens).

To provide insight into the magnitude of the effect of FDI inflows on government confidence in authoritarian countries, Figure 4 below graphs the predicted probabilities of survey respondents indicating great confidence in government.

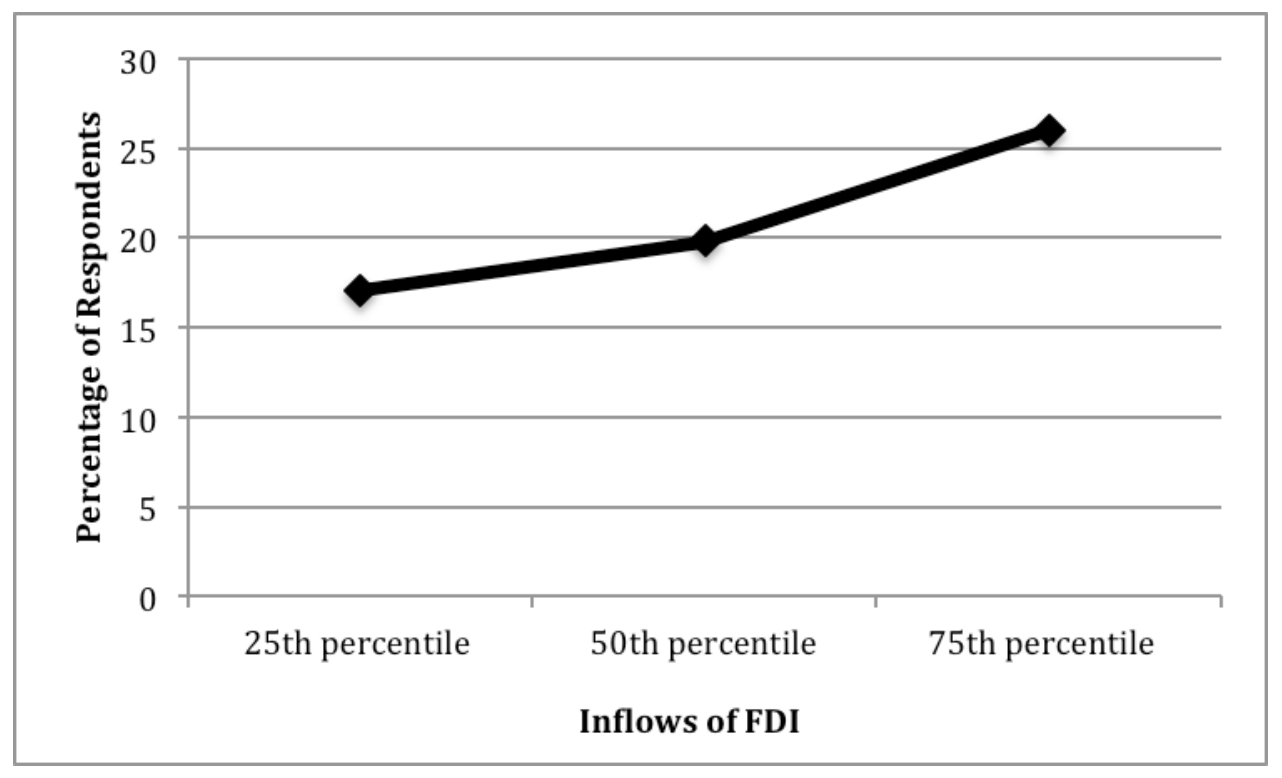

Figure 4 Predicted Probabilities of Respondents who Indicate Great Confidence in Government

Respondents in a country in the lowest quartile of FDI inflows (like Zimbabwe) have a predicted probability of 17 percent in selecting the highest confidence in government, while respondents in a country in the highest quartile (like Egypt) have a predicted probability of 26 percent. Overall, in authoritarian countries, survey respondents associate greater inflows of FDI with greater confidence in government, thereby lending strong support to the microfoundation of my argument that citizens find FDI inflows to be desirable. As governments advance policies that attract and sustain FDI inflows, they are pursuing policies that are preferred by the majority of the country. Thus, authoritarian leaders who rely on participatory and welfare-enhancing 
policymaking can adopt FDI friendly policies to maintain support and confidence among the populous.

These estimation results are robust to a different specification of the independent variable of interest (FDI inflows in current US dollars logged), the exclusion of the objective measure, and Marshall and Gurr's (2008) classification for the sample. See Table 9, 10, and 11 in Appendix B for results.

\subsection{ORIGINAL SURVEY EVIDENCE ON BUSINESS PREFERENCES}

I conducted an original survey of U.S. multinational companies to gather primary evidence of business preferences for and experiences in investing in authoritarian countries. This survey addresses a gap in the political science literature as few studies use survey evidence to analyze how businesses assess and mitigate political risk (Biglaiser and Staats 2010, 2012). Furthermore, despite the burgeoning bilateral investment treaty research, few studies have sampled businesses on their perceptions of the utility and function of BITs (Buthe and Milner 2009).

The survey population is multinational companies with headquarters in the United States that invest in developing countries. Language and data constraints inhibited me from collecting sample lists and survey data from non-U.S. companies. However, the U.S. makes up over twenty percent of worldwide foreign direct investment outflows, the largest percent of any country (for instance, the second highest is Japan at six percent) (UNCTAD 2011b). Thus, my survey is effective in gathering evidence on investor preferences from the most prominent home country actor in foreign direct investment flows. Additionally, the surveyed U.S. managers invest across the developing world, so the variation in host country location will provide evidence on how 
investors mitigate political risk across different authoritarian regimes. Chief executive and financial officers and upper-level managers are the targeted respondents of my survey because they have the most information and knowledge regarding investment decisions (Biglaiser and Staats 2010).

The source of the sample list is the Uniworld Business Publications Directory. Uniworld Business Publications provides contact information, investment locations, industry sector, total revenue, and number of employees for all U.S. multinational companies. This directory has been used in many academic publications (Biglaiser and Staats 2010, 2012, Dreiling and Darves 2011, Musteen, Rhyne, and Zheng 2012) and subscribers of Uniworld Business Publications include universities, business organizations (like Chamber of Commerce), libraries, and the U.S. government.

I created an online version of my survey using Survey Monkey. When conducting the survey, I first sent an introductory script to each company with a listed email address. This script contained an introduction to the project, a letter from the Dean of the Graduate School of Public and International Affairs, and a link to the survey. As the email list was fairly comprehensive (4601 out of 5112 companies listed) and representative (the difference in the mean of employment and sales values of all data and data with emails were minimal- less than one percent difference), I emailed my survey to all companies who had listed email addresses and chose not send the survey via the postal service.

The survey starts with a consent script, following the University of Pittsburgh's Institutional Review Board's procedures. Survey questions then address what national and international institutions ensure secure property right protections and profitable operations for multinational businesses operating in authoritarian countries. Specifically, I ask about the role of 
bilateral investment treaties, host country political institutions and freedoms, business associations, and other non-governmental organizations in ensuring secure property right protections and efficient, stable, and profitable operations for business managers investing in nondemocratic countries. Please see Appendix E.1 for a copy of the survey questionnaire.

Between January and April 2013, fifty-three individuals answered the survey, although only eighteen answered all the questions on investing in authoritarian countries. Twenty-one (of the fifty-three) respondents indicated that their companies do not invest in developing or authoritarian countries. Ninety percent of the respondents who indicated their company did not invest in authoritarian regimes cited a lack of customer base as the reason. However, forty percent also indicated government interference in business operations as another reason for the lack of investment in authoritarian regimes, thus lending support to the high levels of political risk in authoritarian countries. The response rate is the major limitation of the survey (please note that surveys to businesses have a notoriously low response rate of ten percent or less, see Biglaiser and Staats (2010) for an overview) and I hope to further develop this survey through the mail and phone in order to increase response rates.

In general, the respondents were highly qualified and company size was evenly represented. Among the fifty-three respondents, only twenty percent did not have input in the decision of the company to invest abroad thereby highlighting that, overall, the respondents were actively involved in decision-making concerning investment decisions. Forty-three percent of the respondents worked for a company with an annual revenue range of fifty million dollars or less and fifty-eight percent of respondents' companies had less than 500 full-time employees. Thus, the sample was fairly divided between small and large size companies. Please see Appendix E.2 for summary tables of all survey answers. 
This survey provides primary evidence on three key aspects of my theory: (1) the significance of bilateral investment treaties to multinational companies investing in authoritarian countries, (2) the significance of civil society organizations and associational freedoms to multinational companies investing in authoritarian countries, and (3) investor perceptions of citizen support for foreign investment in authoritarian countries. Overall, I find strong support for the theoretical foundations of my argument as multinational companies value BITs as a signal of liberal economic policies, associate freedoms of association with secure property right protections and profitable operations, and perceive strong support for the foreign investment by citizens in host authoritarian countries.

First, I asked two questions concerning what domestic and international institutions were valuable in securing property right protections and profitable operations in the authoritarian country in which the respondent's company has operations. Specifically, the question was: Currently how valuable to ensuring property right protections (or profitable operations) are the following for your company? The answer options were a five-point scale from not valuable to extremely valuable. Around fifty percent of respondents indicated business associations and the freedom of association as very or extremely valuable in ensuring both secure property rights and profitable operations; while, close to thirty percent of respondents indicated BITs as very or extremely valuable for these issues. This contrasts sharply with less than ten percent of respondents selecting an elected legislature as very or extremely valuable in ensuring profitable operations. Figure 5 below provides detailed evidence on the percentage of respondents who selected very or extremely valuable in association with various institutions in protecting property and profit. 


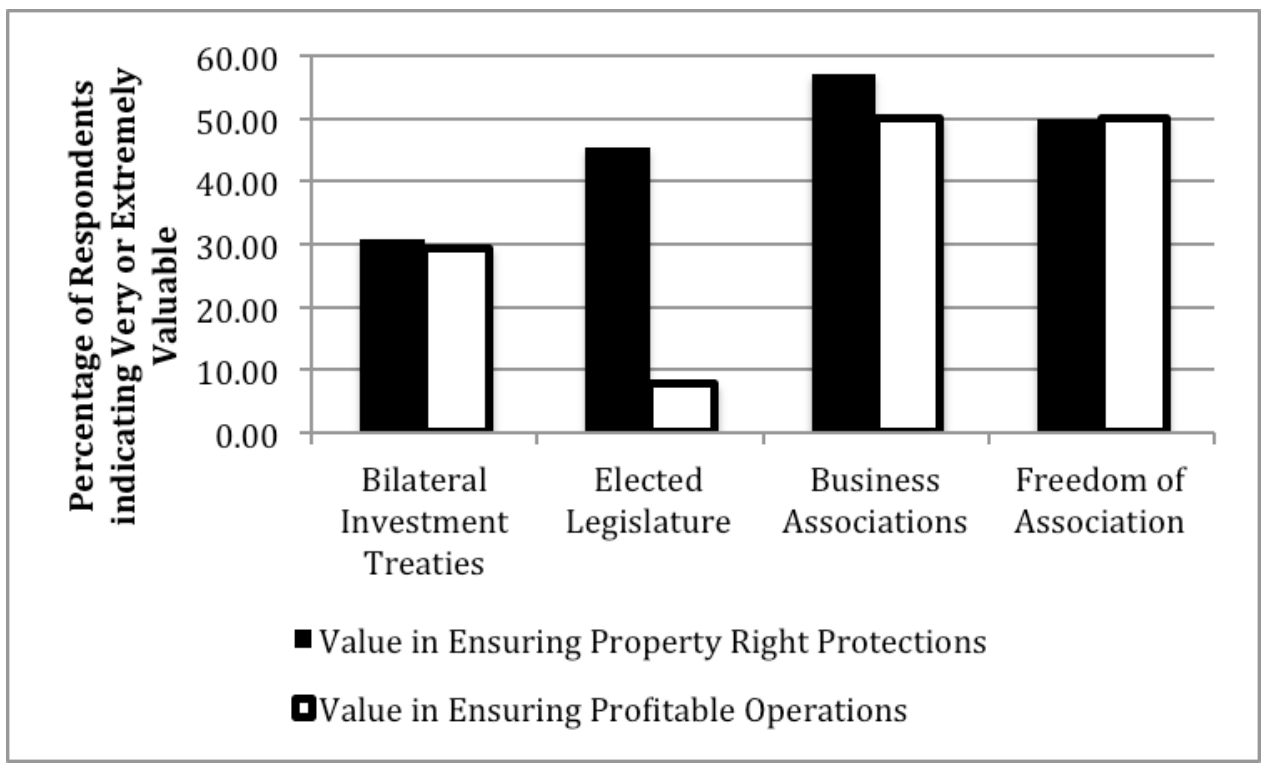

Figure 5 Value of Domestic and International Institutions in Securing Property Rights and Profit

The answers to this initial question provide evidence in strong support of multinational companies awareness of and value for civil society organizations. Importantly, both measures of citizen participation (business associations and freedom of assembly) were more highly valued than the formal political institution of the legislature in both ensuring property right protections and profitable operations. However, the results to this survey question also highlight the inability of bilateral investment treaties to be a credible commitment of property right protections for many investors investing in authoritarian countries as only thirty percent of respondents found BITs to be very or extremely valuable in ensuring property right protections.

In order to further assess the significance of international investment treaties, I included a survey question on the value of BITs (signed by authoritarain countries in which the respondent's company has operations) in signaling FDI friendly policies. The overwhelming majority (sixty-five percent) of respondents indicated that BITs are somewhat, very, or extremely valuable in signaling a signatory’s commitment to liberal economic policies (on a five point scale from not valuable to extremely valuable). Figure 6 highlights this statistic. 


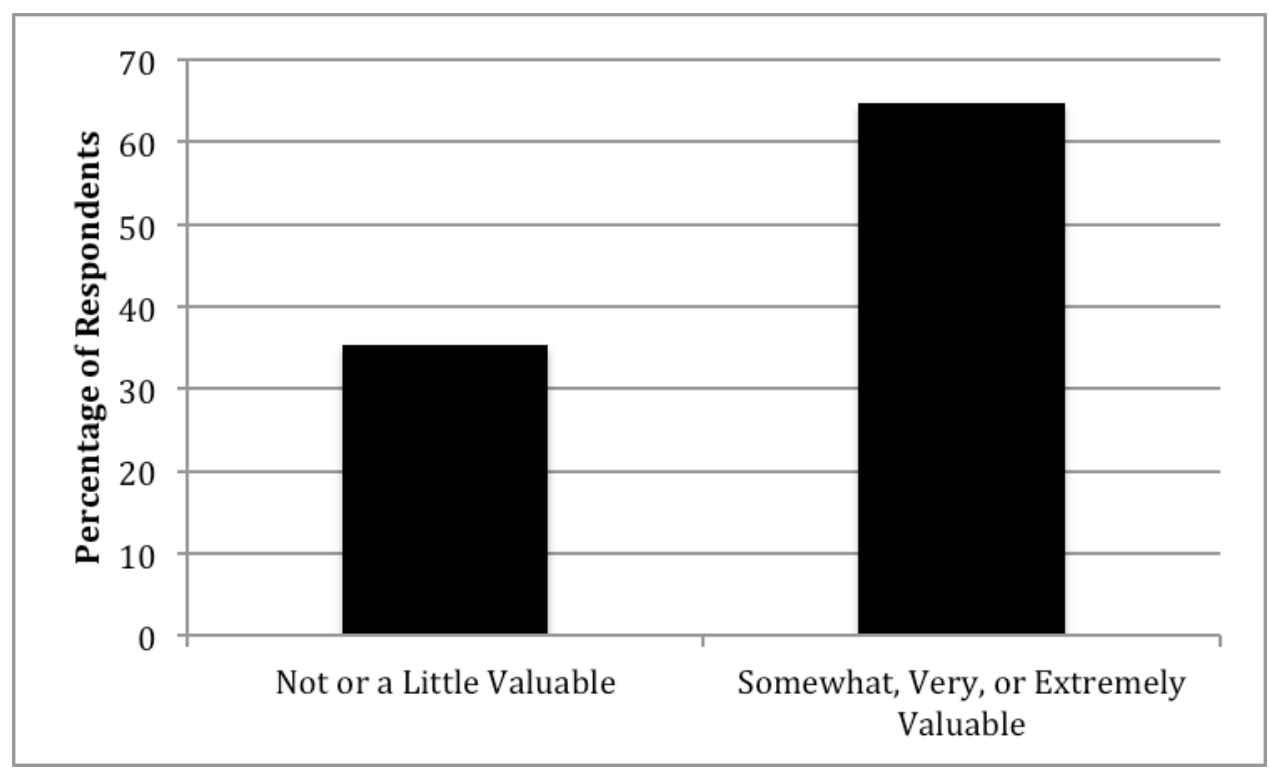

Figure 6 Value of BITs in Signaling a Commitment to Liberal Economic Policies

Ultimately, the results of this survey indicate the power of BITs as a signaling device of liberal economic policies as opposed to a credible commitment of property right protections for multinational companies.

The survey then included several questions on the respondent's company's experiences with various civil society organizations in authoritarian countries in order to further evaluate the significance of freedoms of association for foreign investors in their investments abroad. Figure 7 below describes how often the respondent's company works with business associations, nongovernmental organizations, and chamber of commerces. 


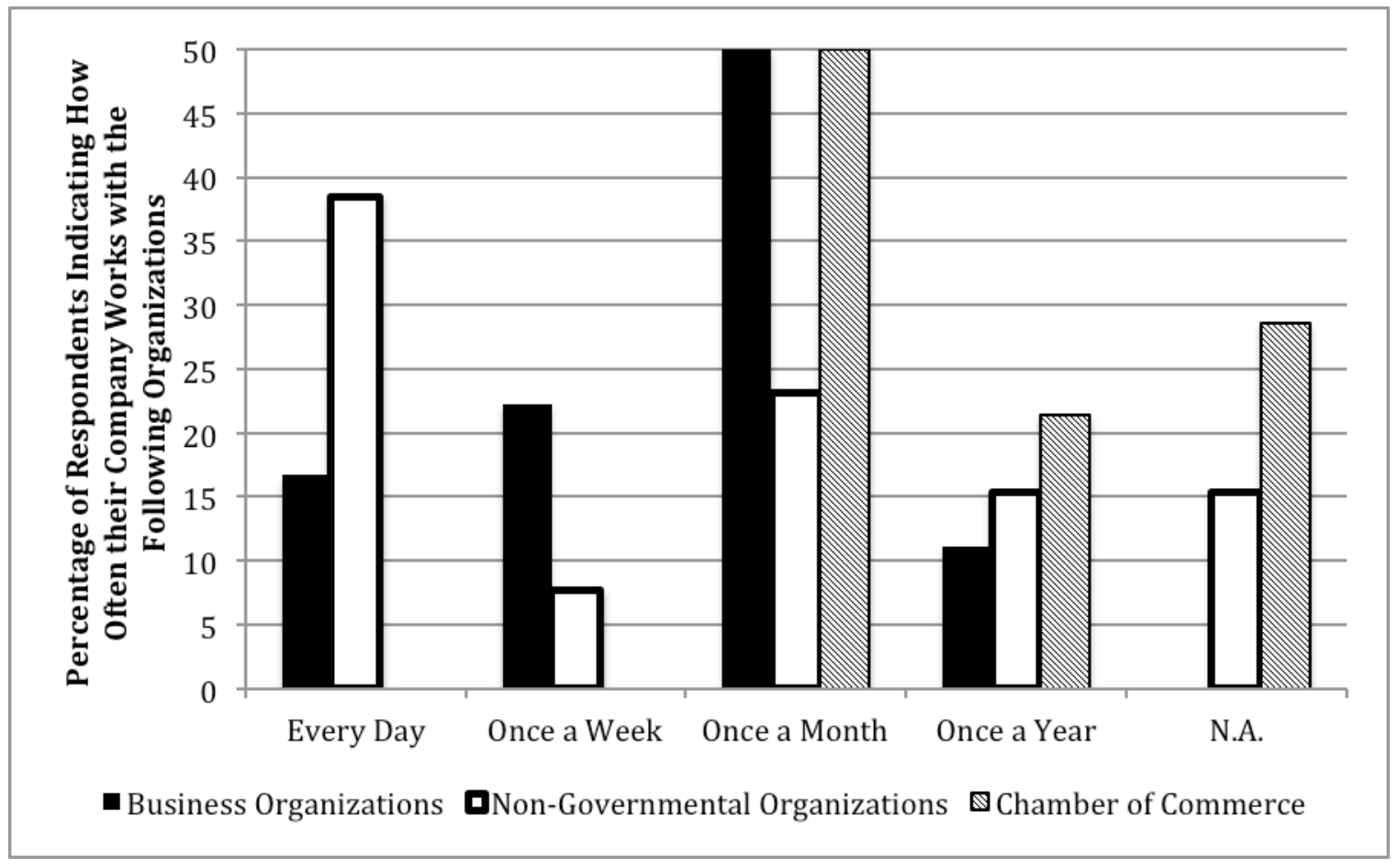

Figure 7 How Often Businesses Work with Civil Society

This figure highlights how the majority of multinational companies work with both business associations and civil society organizations very often (once a month or more) in authoritarian countries. Half of the respondents indicated working with business associations and chamber of commerces once a month, while nearly forty percent of respondents work with nongovernmental organizations every day. Furthermore, the survey reveals that a major purpose of the contact with business associations is establishing business and government networks in the host country. Half of the survey respondents indicated that working with business associations was very or extremely valuable in providing access to business networks and close to forty percent of the respondents found business associations very or extremely valuable in accessing government networks.

Finally, I included a question concerning citizen support for foreign investment in authoritarian countries in order to provide additional evidence on citizen preferences for FDI. My 
original survey results corraborate the survey results reported earlier from the PEW and ASES surveys: close to ninety percent of the respondents indicated moderate to very strong citizen support in the authoritarian country their company invests. Figure 8 below provides descriptive statistics on this question.

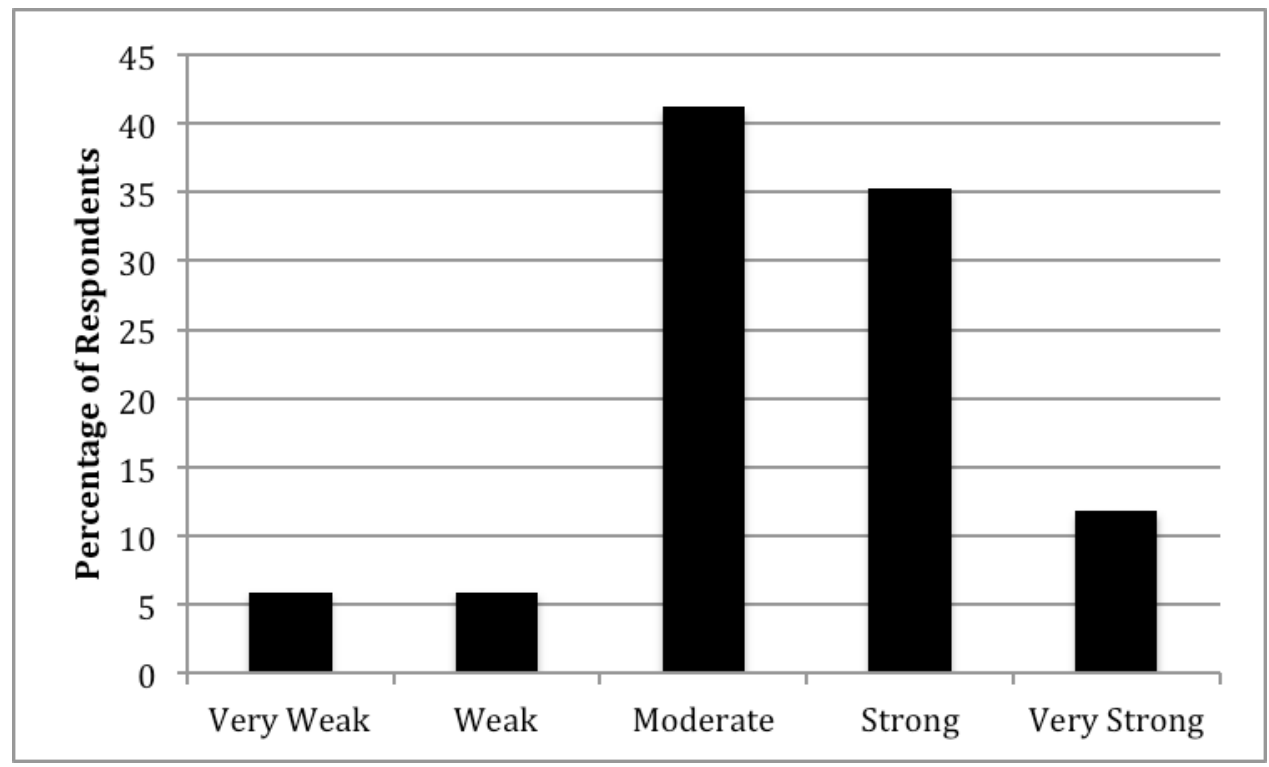

Figure 8 Business Perceptions of Citizen Support for FDI

Only a little more than ten percent of respondents indicate very weak or weak citizen support for foreign investment. Thus, in conjunction with survey reports and results in section 4.1, the data is consistent in showing strong citizen support for foreign investment in authoritarian regimes.

\subsection{SUMMARY OF RESULTS}

Overall, the primary evidence reported and analyzed in this chapter presents strong support to the microfoundations of my theory. Survey data from individuals living in and foreign investors investing in authoritarian countries indicates strong citizen support for FDI inflows. Further, evidence linking greater inflows of FDI with greater confidence in government shows that 
citizens in authoritarian countries view attracting FDI as beneficial for their nations. These results highlight the foundations of my argument that if authoritarian leaders rule by participatory and welfare-enhancing policymaking they will, first, receive societal feedback on the benefits of FDI and, second, maintain confidence and support by pursuing FDI friendly policies.

Survey results from my original survey of U.S. multinational companies provide preliminary evidence that foreign investors do value both BITs and citizen participation, the two factors I hypothesize attract FDI to authoritarian countries ${ }^{22}$. Foreign investors are aware of and actively involved in civil society in authoritarian countries. In fact, multinational companies cited both the freedom of assembly and business associations as very valuable in ensuring strong property right protections and profitable operations abroad. Additionally, instead of being a credible commitment to protecting property (only thirty percent of respondents associated BITs with being very or extremely valuable in protecting property rights), BITs are associated with signaling a host country's dedication to liberal economic policies (over sixty percent of respondents indicated BITs are somewhat to extremely valuable in signaling liberal economic policies). This primary evidence on foreign investor preferences when investing abroad corroborates the foundations of my theory on the role of domestic and international institutions reducing political risk and attracting foreign investment to authoritarian regimes.

Ultimately, this analysis contributes to a gap in the international political economy literature on preferences for FDI in the developing world. Extensive literature on societal preferences for trade exists within the discipline (Rogowski 1987, Frieden 1991, Hiscox 2001) and Scheve and Slaughter (2004) evaluate perceptions of economic insecurity associated with

\footnotetext{
${ }^{22}$ Please note the limited number of respondents.
} 
FDI inflows, however little research addresses attitudes towards FDI in the developing world. Thus, my empirical findings play a key role in providing initial evidence on aggregate preferences for FDI in authoritarian countries. 


\subsection{EMPIRICAL ANALYSIS}

Regression analysis will be used to test the hypothesis that authoritarian regimes with BITs and high levels of citizen participation attract the most foreign direct investment inflows. It is hypothesized that BITs are most effective in attracting inflows of FDI in authoritarian regimes with high levels of citizen participation.

\subsection{DESCRIPTION OF VARIABLES}

Regime type is classified according to Przeowrksi, Alvarez, Cheibub and Limongi’s (2000) criteria. A regime is defined as authoritarian if at least one of the following conditions hold: the chief executive is not elected, the legislature is not elected, there is no more than one party, the incumbents will have or already have held office continuously by virtue of elections for more than two terms or have held office without being elected for any duration of their current tenure in office, and until today or until the time when they were overthrown they had not lost an election (Przeworski, Alvarez, Cheibub, and Limongi 2000). Specifically, the data is taken from Cheibub et al's (2009) dataset, which builds on Przeworksi et al's (2000) classification. ${ }^{23}$

${ }^{23}$ Other measures of democracy correlate very strongly with this classification of authoritarianism. The correlation between Cheibub et al (2009)'s measure of regime type and Marshall and Gurr (2008)'s polity is 0.82 . Ninety-five percent of the country years classified as 
The dependent variable is inflows of FDI in current U.S. dollars (logged) (World Bank 2011). The log of FDI inflows is the dependent variable in order to best capture the amount of investment; FDI as a percent of GDP reflects openness (Li 2009b). ${ }^{24}$

The first independent variable of interest is operationalized as the total number of bilateral investment treaties in force (with any country) (UNCTAD 2011). The average number of bilateral investment treaties authoritarian countries have in force is close to 4 (3.72) and the standard deviation is close to 9 (8.77). In the past two decades, the number of BITs in force has increased tremendously. Figure 9 below captures this trend:

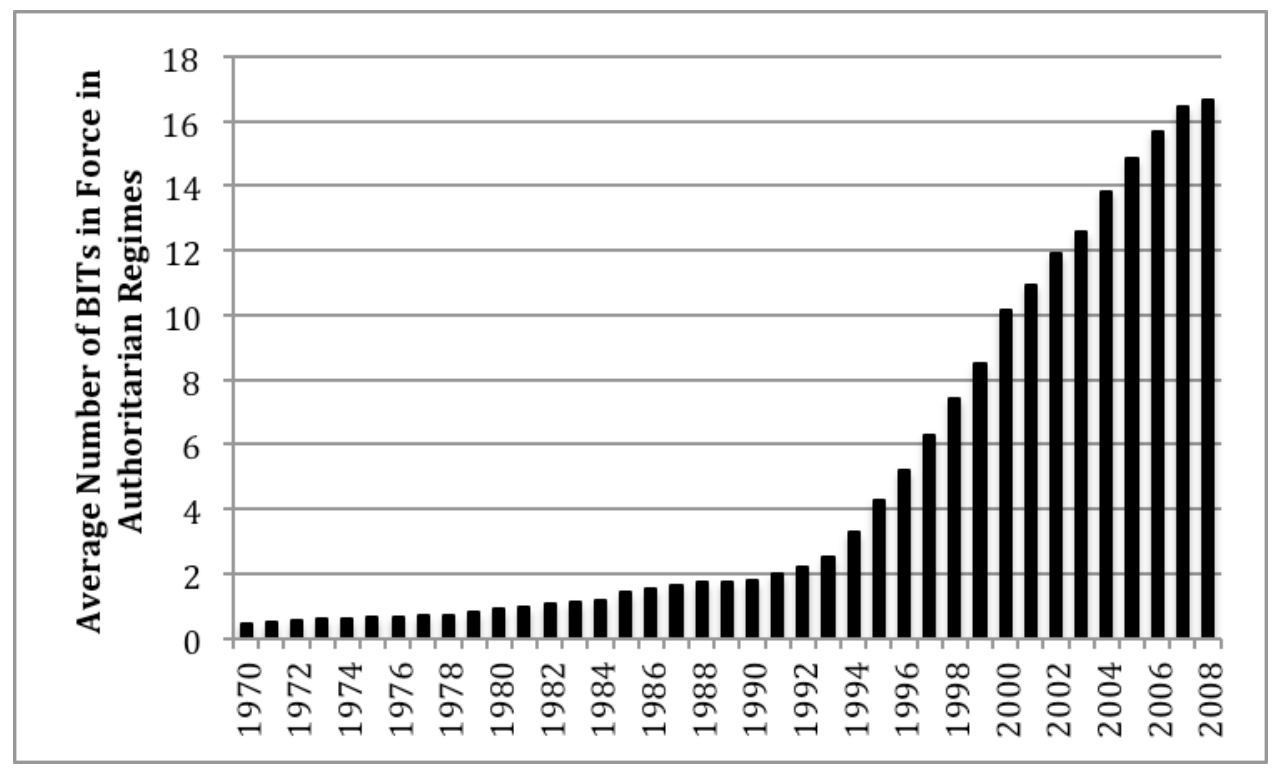

Figure 9 Average Number of BITs in Force in Authoritarian Countries

However, despite the great overall increase in BITs, there exists variation in the number of BITs in force among different authoritarian countries. Figure 10 highlights the variation in BITs in force in 2008.

authoritarian in Marshall and Gurr (2008) are also authoritarian according to Cheibub et al (2009).

${ }^{24}$ Robustness tests with FDI as a percent of GDP are conducted and results are robust. See Table 14 in Appendix C. 


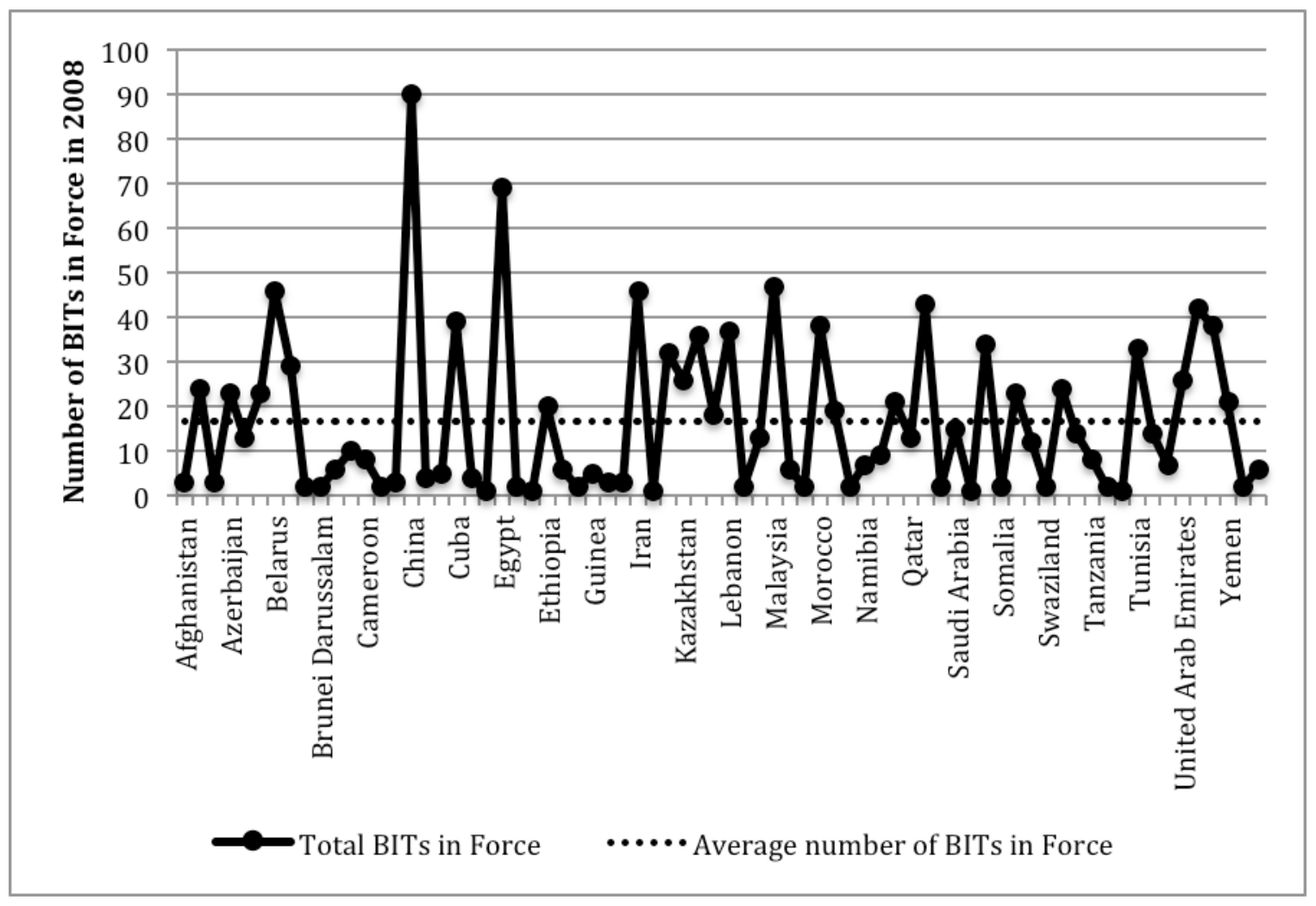

Figure 10 Number of BITs in Force in Authoritarian Countries in 2008

While China and Egypt have the most bilateral investment treaties in force (90 and 69, respectively), many authoritarian countries have very few BITs, such as Botswana (2), Iraq (1), Myanmar (2), and Zambia (2). Thus, while the total number of BITs signed is increasing overall, disaggregating this trend reveals variation among authoritarian countries in their willingness to enter into international investment contracts.

Following Chandra and Rudra (2011), the second independent variable of interest, citizen participation, is operationalized by Marshall and Gurr's (2008) PARCOMP. PARCOMP is defined as "the degree to which political participation is free from government control," (69) and Marshall and Gurr (2008) explain that PARCOMP depends on civil interaction. PARCOMP is measured on a five-point scale with high values indicating high degrees of citizen participation. Specifically, the scale from one to five is defined as: repressive (no significant oppositional 
activity permitted), suppressive (some organized opposition outside the government), factional (parochial or ethnic based factions), transitional (competing interests but not fully linked with broader interests), and competitive (stable and enduring political groups) (Marshall and Gurr $2008)^{25}$.

Citizen participation is not an alternative measure of democracy. In fact, the level of citizen participation varies across the democratic and authoritarian developing world. Table 2 below presents cases of high and low citizen participation in democratic and authoritarian countries. In this analysis, the focus is on countries that are authoritarian (low levels of democracy in Table 2) but have relatively high levels of citizen participation (see highlighted box).

Table 2 Citizen Participation and Democracy in the Developing World in 2008

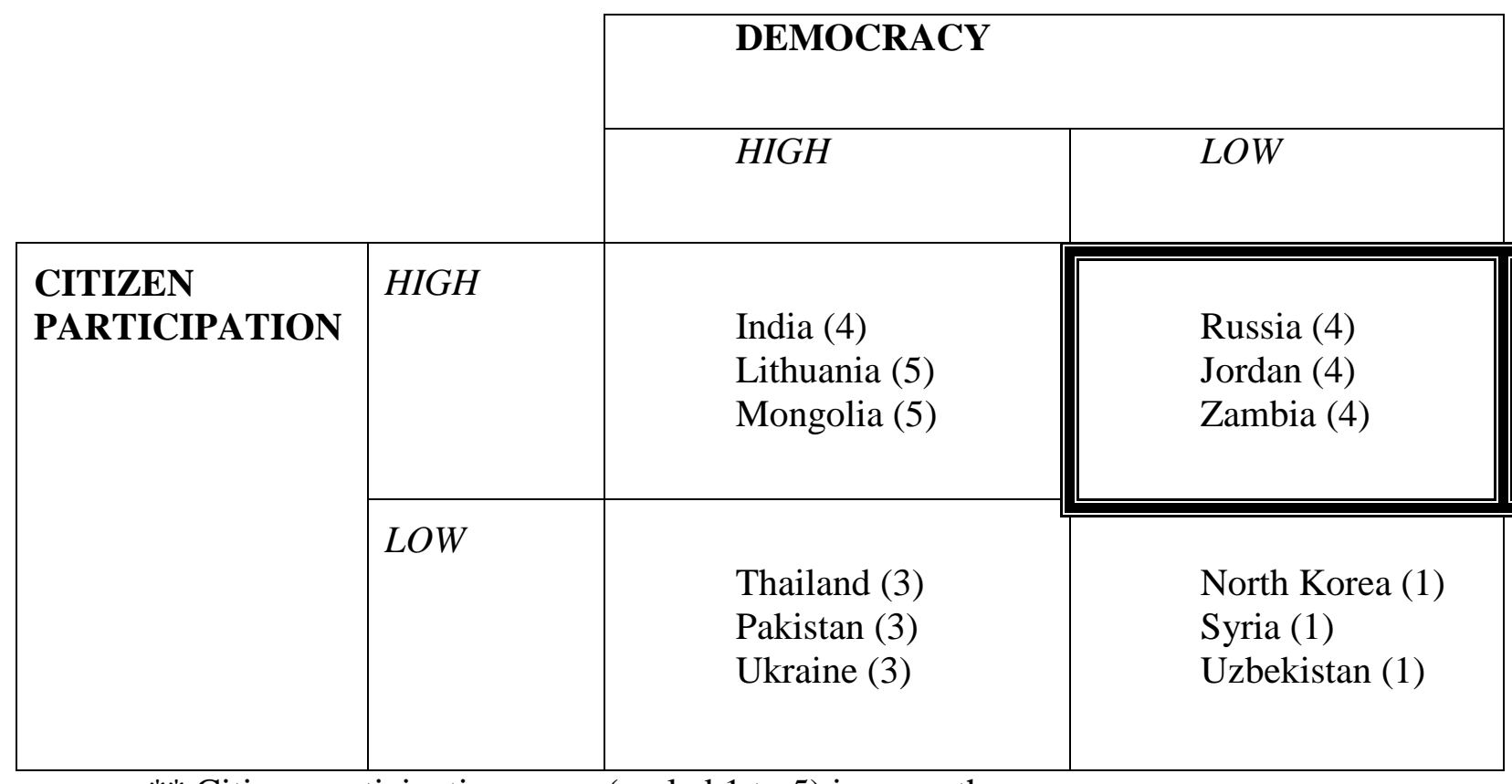

** Citizen participation score (scaled 1 to 5 ) in parentheses

${ }^{25}$ In the developing world, the level of citizen participation is not time invariant. For example, the average difference in PARCOMP scores in a country over ten years is close to half a point with a standard deviation of one point. 
However, the theory on citizen participation constraining leaders is especially powerful in authoritarian cases because in these countries the rule of law is weak and formal institutions are often ineffective (as discussed previously). In fact, Chandra and Rudra (2011) find that the threshold for citizen participation affecting policy stability is low in authoritarian countries- even modest levels of citizen participation can greatly influence national decision-making processes.

Unlike formal domestic institutions in authoritarian governments, the level PARCOMP varies across authoritarian regimes. Figure 11 below highlights the variation in citizen participation in authoritarian countries in 2008.

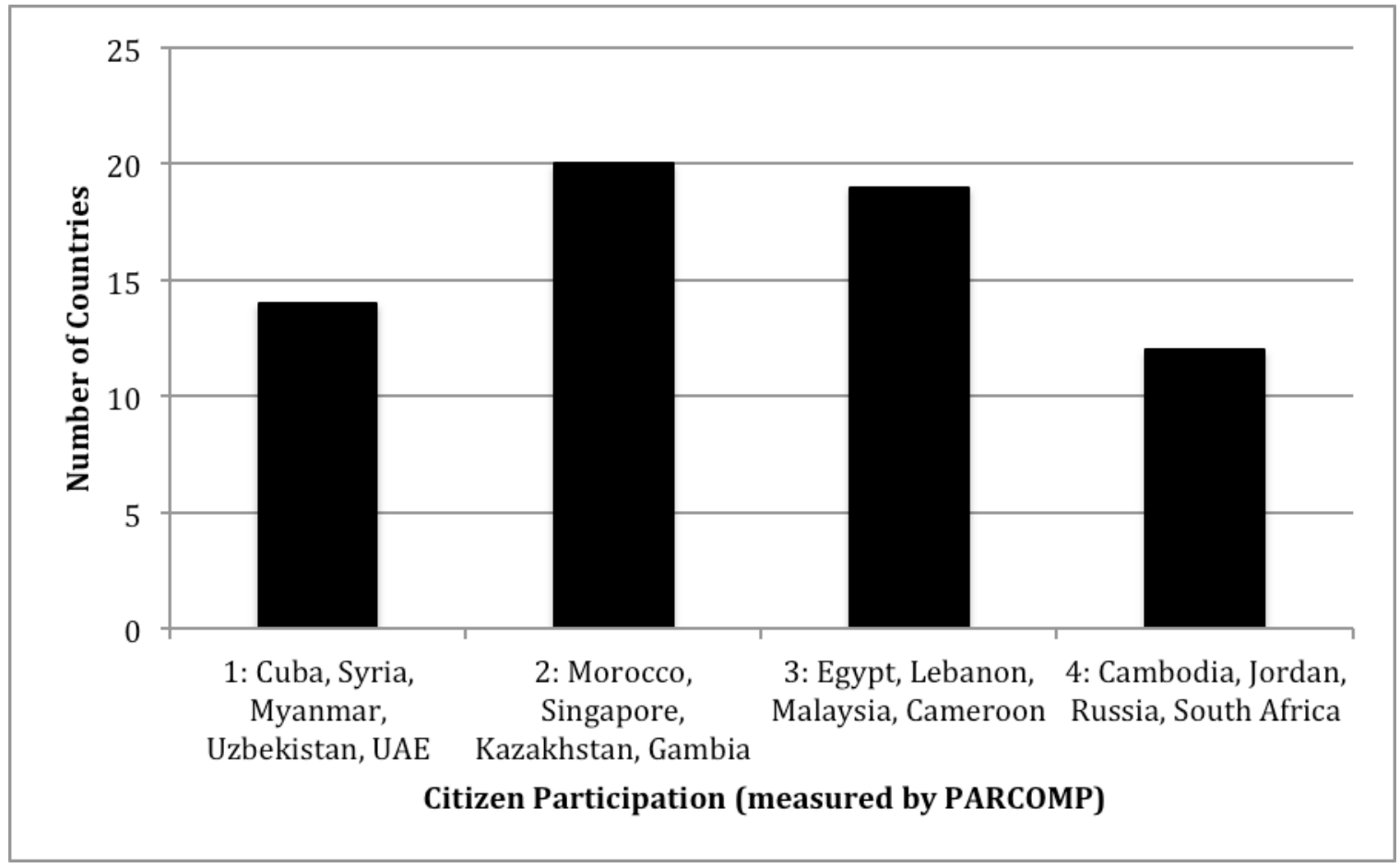

Figure 11 Citizen Participation in Authoritarian Countries in 2008

This figure contrasts sharply with the variation of legislatures in authoritarian countries. Figures 22 and 23 in Appendix C indicate the number of country-years with differing modes of 
legislature selection and levels of citizen participation. Between 1990 and 2008, regimes were almost evenly split between repressive, suppressive, and factional levels of citizen participation, while the overwhelming majority (71 percent) of these same regimes had elected legislatures. ${ }^{26}$ In addition, Table 12 in Appendix $\mathrm{C}$ highlights the variation of citizen participation within categories of authoritarian regime type (civilian, military, royal) and countries with elected legislatures. The level of citizen participation provides a more nuanced measure of the constraints on the authoritarian leader than other measures of formal political institutions or power relations.

Preliminary evidence provides support for the hypothesis that in authoritarian regimes with high levels of citizen participation, dictators exhibit lower levels of rent-seeking behavior. Figure 12 below highlights how authoritarian regimes with higher levels of PARCOMP have lower levels of expropriation (Li 2009a).

${ }^{26}$ Other measures of formal institutions present similar trends. For example, since 1990, 56 percent of authoritarian country-years have multiple parties in the legislature, while only 29 percent and 15 percent have no legislature or the regime party only in the legislature, respectively (Cheibub et al 2009). Similarly, the overwhelming majority of authoritarian governments have no veto players (74 percent) (Henisz 2000). 


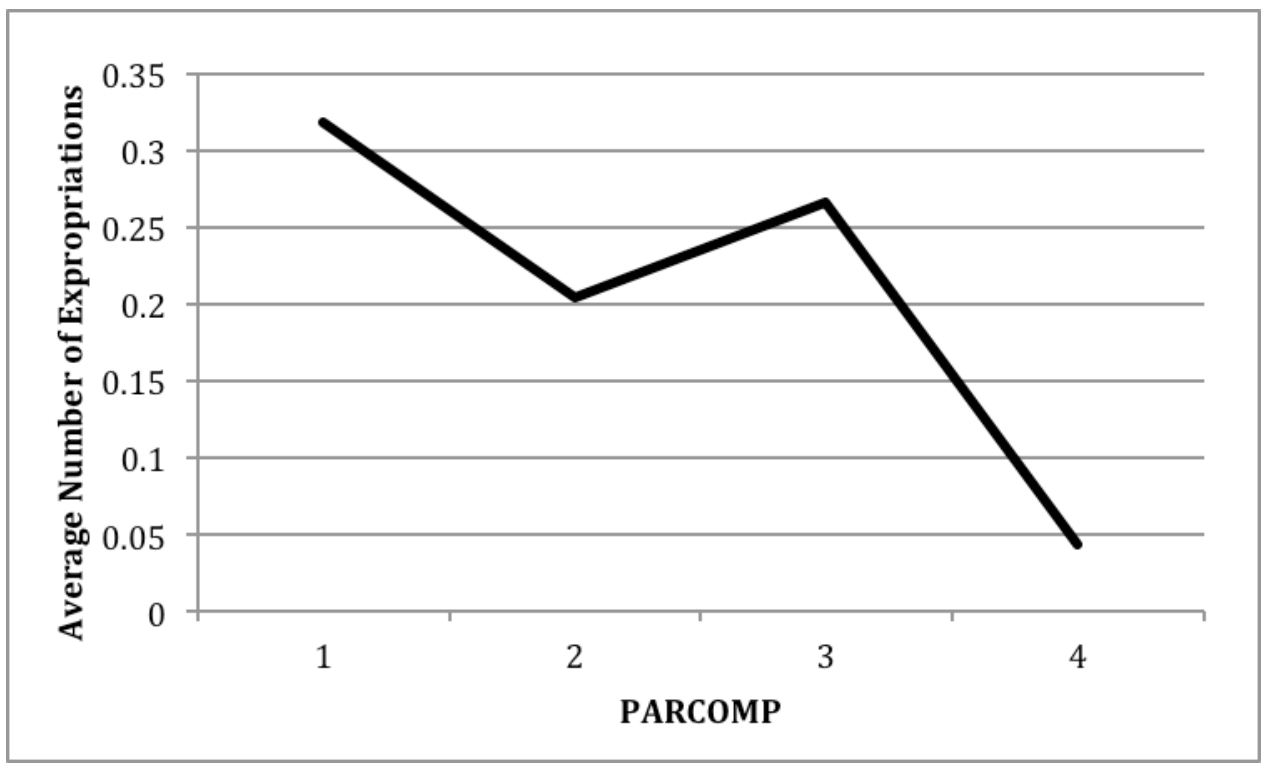

Figure 12 Expropriation in Authoritarian Countries between 1960 and 1990

PARCOMP is positively associated with policy stability ${ }^{27}$. As discussed previously, in regimes with high levels of citizen participation, leaders receive information on the policy preferences and consequences, thereby leading to incremental decision-making ${ }^{28}$. To test the determinants of policy stability, I estimate a fixed effects regression with PARCOMP as the independent variables of interest. The dependent variable, policy stability, is measured as the standard deviation of the growth rate, a widely accepted measure of stability in the political science literature (Henisz 2004, Quinn and Woolley 2001, Chandra and Rudra 2011). Higher values indicate greater policy instability (as the standard deviation of the growth rate is larger), thus the dependent variable is labeled as policy instability. Building on Chandra and Rudra

${ }^{27}$ Please note that in authoritarian countries PARCOMP is not highly correlated with the rule of law (0.03).

${ }^{28}$ Citizen participation is a better measure of policy stability than political risk. Political risk is a broad measure that does not concisely capture policy stability; it also surveys additional environmental factors such as governance institutions, corruption, and conflict. Further, political risk includes measures that do not determine FDI inflows (military in politics, religion in politics, presence of a competitive legislature) (Busse et al 2007, Qian and Baek 2011, Jensen, Malesky, and Weymouth 2012). 
(2011), I control for GDP per capita, primary school enrollment, trade, and veto players (World Bank 2011, Henisz 2004). Estimation results in Table 3 below highlight how PARCOMP is a key indicator of policy stability.

Table 3 Determinants of Policy Stability in Authoritarian Countries: A Panel Regression

\begin{tabular}{lll}
\hline & (Policy Instability) & (Policy Instability) \\
\hline & & \\
PARCOMP & $\mathbf{- 0 . 6 2 3 * * *}$ & $-\mathbf{0 . 4 7 7 * * *}$ \\
GDP per capita & $\mathbf{( 0 . 1 1 7 )}$ & $\mathbf{( 0 . 1 2 2 )}$ \\
& & $-1.145^{* * *}$ \\
Primary School Enrollment & $(0.190)$ \\
& & 0.00358 \\
Exports (\% GDP) & $(0.00635)$ \\
& & -0.00267 \\
Veto Players & & $(0.00762)$ \\
& & $-1.310^{* * *}$ \\
Observations & & $(0.455)$ \\
R-squared & 2,364 & 1,894 \\
Number of countries & 0.013 & 0.054 \\
\hline Standard errors in parentheses & 114 & 108 \\
\hline
\end{tabular}

The marginal effect of PARCOMP on policy instability is negative and statistically significant, thus highlighting how greater citizen participation in authoritarian countries is associated with less policy instability (or increased policy stability).

In the following analysis, as a robustness check, I use freedom of assembly and association from the Cingranelli-Richards (CIRI) Human Rights Dataset as another measure of citizen participation. Freedom of assembly measures "the extent to which freedoms of assembly and association are subject to actual government limitations or restrictions.” It is scaled from zero to two with zero indicating restrictions on or denials of freedom of assembly and association, one indicating these freedoms are limited across the greater population, and two indicating unrestricted rights for practically all citizens. 


\subsection{HYPOTHESIS}

My hypothesis predicts that authoritarian regimes will be most successful in attracting FDI inflows when they have BITs and high levels of citizen participation. The bilateral investment treaties signal willingness by the government to attract and sustain FDI inflows, while high levels of citizen participation constrain the leader's volatile decision-making, thus ensuring stability to the FDI friendly policies. As such, countries with few BITs or low levels of citizen participation will be less successful in attracting FDI as they fail to demonstrate a dedication to attracting FDI and/or do not have constraints ensuring the investor of policy stability. In both of these instances, the foreign investor is not assured that the government will respect his property and rights. Table 4 below provides a box with case examples of countries with varying degrees of BITs and citizen participation (measured by PARCOMP). The highlighted box refers to those countries that are expected to attract the most FDI inflows.

Table 4 Citizen Participation and BITs in Force in Authoritarian Countries in 2008

\begin{tabular}{|c|c|c|c|}
\hline & & \multicolumn{2}{|l|}{ BITS in FORCE } \\
\hline & & HIGH & LOW \\
\hline PARCOMP & HIGH & $\begin{array}{l}\text { Egypt }(3,69) \\
\text { Russia }(4,43) \\
\text { Jordan }(4,32) \\
\text { Singapore }(2,34) \\
\\
\text { Average FDI Inflows } \\
\text { Logged: } 23.2 \\
\text { Percent GDP: } 6.9\end{array}$ & $\begin{array}{l}\text { Angola }(4,3) \\
\text { Zambia }(4,2) \\
\text { Cameroon }(3,8) \\
\text { Average FDI Inflows } \\
\text { Logged: } 20.3 \\
\text { Percent GDP: } 3.1\end{array}$ \\
\hline
\end{tabular}




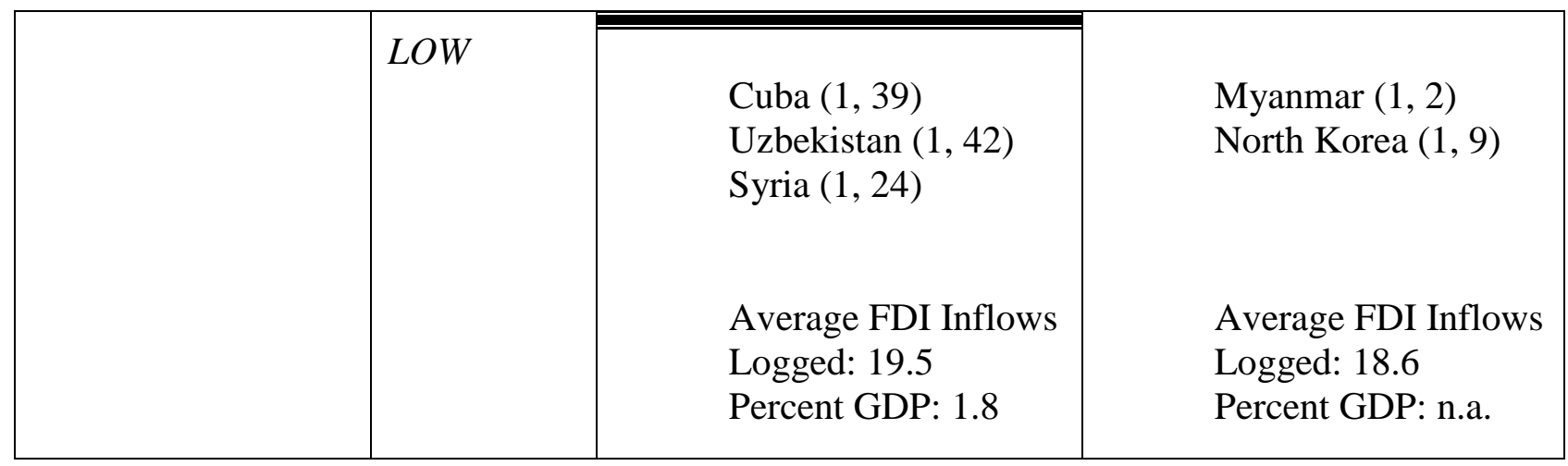

** Citizen participation (scaled 1 to 4 ) and total BITs in force in parentheses

Preliminary evidence of the average FDI inflows of the case examples supports my hypothesis: countries with BITs and high levels of citizen participation attract the most FDI inflows (23.2 U.S. dollars logged), while countries with lower levels and fewer BITs attract less (20.3 and 19.5 U.S. dollars logged). Countries with few BITs and low levels of citizen participation attract the least FDI inflows (18.6 U.S. dollars logged).

\subsection{MODEL AND EMPIRICAL RESULTS}

Following Neumayer and Spess (2005), the regression model controls for economic conditions, risk, and country demographics. The independent variables capturing the economic conditions of the host country include gross domestic product (GDP) growth and oil rents (as a percent of GDP) (World Bank 2011) ${ }^{29}$. Risk is measured with an economic variable and a political variable: inflation (consumer prices annual percent) and rule of law, respectively (World Bank 2011,

${ }^{29}$ Results are robust when including mineral rents as a percent of GDP as a substitute for oil rents as a percent of GDP. 
World Bank 2010) ${ }^{30}$. The total population (logged), life expectancy, and GDP per capita (logged) capture the country's economic and human development and demographics (World Bank 2011). I also include a dummy variable that is one if the country has ever been considered democratic $^{31}$. See Table 30 in the Appendix D for all variable descriptions. Specifically, the model is:

$$
\begin{gathered}
\text { FDI }_{\text {it }}=\beta_{0}+\beta_{1} * \text { BIT }_{\text {it }}+\beta_{2} * \text { PARCOMP }_{\text {it }}+\beta_{3} * \text { BIT }^{*} \text { PARCOMP }_{\text {it }}+\beta_{4} * \operatorname{Law}_{\text {it }}+ \\
\beta_{5} * \text { GDPgrowth }_{\text {it }}+\beta_{6} * \text { Population }_{\text {it }}+\beta_{7} * \text { Inflation }_{\text {it }}+\beta_{8} * \text { Oil }_{\text {it }}+\beta_{9} * \text { Life }_{\text {it }}+\beta_{10} * \text { GDPpC }_{\text {it }}+ \\
\beta_{11} * \text { Democracy }_{\text {it }}
\end{gathered}
$$

Panel data is used to ensure that spillover effects are captured in the statistical analysis and to preserve sample size. The panel data is available annually from 1970 through 2008 for 87 authoritarian countries. The sample includes only authoritarian countries ${ }^{32}$, so the data is unbalanced as many countries are not consistently authoritarian from 1970 to 2008 . Please see Table 31 in Appendix D for the countries in the sample. Time dummy variables are also included in the regressions.

${ }^{30}$ Following Neumayer and Spess (2005) inflation is not logged. However, results are robust upon the inclusion of inflation (logged).

${ }^{31}$ The democracy dummy variable is based Marshall and Gurr's (2008) classification of democracy: "Democracy is conceived as three essential, interdependent elements. One is the presence of institutions and procedures through which citizens can express effective preferences about alternative policies and leaders. Second is the existence of institutionalized constraints on the exercise of power by the executive. Third is the guarantee of civil liberties to all citizens in their daily lives and in acts of political participation" (Marshall and Gurr 2008: 14). However, results are robust when including a democracy dummy variable based on Cheibub et al's (2009) classification.

${ }^{32}$ Results are consistent in a full sample of all developing countries. Chandra and Rudra's (2011) theory of policy stability associated with citizen participation applies to both democracies and nondemocracies, thus this statistically significant result in the full sample provides further support to this theory. See Table 19 in Appendix C. 
I run a panel regression with country fixed effects and panel-corrected standard errors based on the model in Neumayer and Spess (2005). Country fixed-effects reduce omitted variable bias and panel-corrected standard errors address autocorrelation. The independent variables of interest are lagged to address endogeneity. I run two base models and a full model with BITs, PARCOMP, and their interaction. Then, I run the full model with freedom of assembly interacted with BITs. All models provide robust results for the independent variables of interest; see Table 5 and Figure 13 below.

Table 5 Determinants of FDI Inflows to Authoritarian Countries: BITs and Citizen Participation

\begin{tabular}{|c|c|c|c|c|}
\hline & (Base) & (Medium) & (Full) & (Robustness) \\
\hline BITs in force & $\begin{array}{l}0.00511 \\
(0.0254)\end{array}$ & $\begin{array}{l}0.00674 \\
(0.0203)\end{array}$ & $\begin{array}{l}-0.00310 \\
(0.0193)\end{array}$ & $\begin{array}{c}0.0303 * * * \\
(0.00948)\end{array}$ \\
\hline PARCOMP & $\begin{array}{l}-0.108 \\
(0.152)\end{array}$ & $\begin{array}{l}-0.250 \\
(0.186)\end{array}$ & $\begin{array}{l}-0.318^{*} \\
(0.182)\end{array}$ & \\
\hline BITs*PARCOMP & $\begin{array}{c}0.0203 * * \\
(0.00835)\end{array}$ & $\begin{array}{l}0.0163^{* * *} \\
(0.00627)\end{array}$ & $\begin{array}{c}0.0169 * * * \\
(0.00561)\end{array}$ & \\
\hline Free Assembly & & & & $\begin{array}{l}-0.0486 \\
(0.120)\end{array}$ \\
\hline BITs*Free Assemble & & & & $\begin{array}{c}0.0106^{*} \\
(0.00572)\end{array}$ \\
\hline Rule of Law & $\begin{array}{c}0.886 * * * \\
(0.113)\end{array}$ & $\begin{array}{l}0.0149 \\
(0.235)\end{array}$ & $\begin{array}{l}-0.144 \\
(0.231)\end{array}$ & $\begin{array}{l}-0.0664 \\
(0.211)\end{array}$ \\
\hline Log Population & $\begin{array}{c}0.651 * * * \\
(0.129)\end{array}$ & $\begin{array}{c}4.274^{* * *} \\
(0.872)\end{array}$ & $\begin{array}{c}2.565^{* * *} \\
(0.729)\end{array}$ & $\begin{array}{c}2.018^{* * *} \\
(0.711)\end{array}$ \\
\hline GDP Growth & & $\begin{array}{c}0.0152 * \\
(0.00784)\end{array}$ & $\begin{array}{c}0.00434 \\
(0.00901)\end{array}$ & $\begin{array}{l}-0.00848 \\
(0.0118)\end{array}$ \\
\hline Life Expectancy & & $\begin{array}{c}0.106^{* * *} \\
(0.0326)\end{array}$ & $\begin{array}{c}0.0879 * * * \\
(0.0324)\end{array}$ & $\begin{array}{c}0.0535 \\
(0.0360)\end{array}$ \\
\hline Oil Rent (\% GDP) & & & $\begin{array}{c}-0.0218^{* *} \\
(0.00879)\end{array}$ & $\begin{array}{c}-0.0195^{* *} \\
(0.00925)\end{array}$ \\
\hline Inflation & & & $\begin{array}{c}2.12 \mathrm{e}-05 \\
(4.99 \mathrm{e}-05)\end{array}$ & $\begin{array}{c}1.81 \mathrm{e}-05 \\
(5.20 \mathrm{e}-05)\end{array}$ \\
\hline Log GDP per capita & & & $\begin{array}{c}0.769 * * * \\
(0.142)\end{array}$ & $\begin{array}{c}1.115^{* * *} \\
(0.202)\end{array}$ \\
\hline
\end{tabular}


Country Fixed

Effects

Decade Dummies

Observations

R-squared

No

Yes

604

0.982

82

Number of Countries

\begin{tabular}{ccc} 
Yes & Yes & Yes \\
Yes & Yes & Yes \\
593 & 511 & 535 \\
0.993 & 0.991 & 0.987 \\
81 & 74 & 76 \\
\hline & $* * * \mathrm{p}<0.01, * * \mathrm{p}<0.05, * \mathrm{p}<0.1$
\end{tabular}

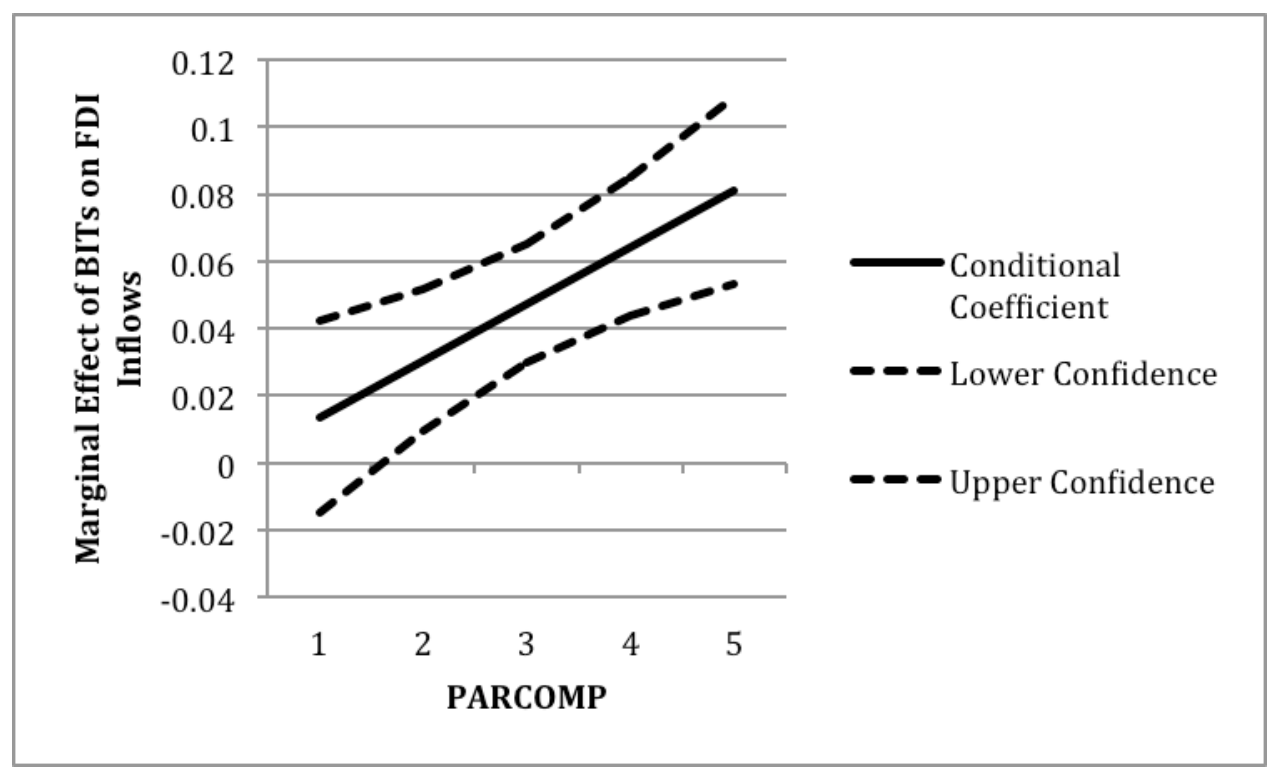

Figure 13 Marginal Effect of BITs on FDI Inflows (Conditional on Citizen Participation)

Figure 13 highlights how having more BITs in force is associated with greater inflows of FDI, given the level of citizen participation. At higher levels of PARCOMP, BITs are associated with greater inflows of FDI than BITs in regimes with low levels of citizen participation. To provide some insight into the magnitude of the effect, a ten percent increase in the number of BITs a country has in force is associated with an increase in FDI inflows of 0.64 points in countries with a transitional PARCOMP (value of 4), while the same increase results in a 0.14 point increase in FDI inflows in countries with a repressive PARCOMP (value of 1). This is 
significant, since within my sample of countries, FDI inflows increase by 0.11 points every year on average.

Additionally, I provide a three dimensional graph of the results in Figure 24 in Appendix C. I graph the marginal effects of BITs and PARCOMP on FDI inflows holding all continuous control variables at their mean and discrete control variables at their mode. This graph highlights the interactive effect of BITs and PARCOMP in attracting FDI inflows to authoritarian countries. Under conditions of no bilateral investment treaties in force, a change in the level of citizen participation from one to four does not increase FDI inflows. Relatedly, when citizen participation is low (PARCOMP equal to one), increasing BITs from zero to twenty only causes a 0.57 percent increase in FDI inflows. However, when citizen participation is high (PARCOMP equal to four), increasing BITs from zero to twenty is associated with a 2.68 percent increase in FDI inflows.

Overall, the control variables' marginal effects are as expected. The economic and development variables (GDP per capita and life expectancy) are consistently positive and statistically significant in predicting inflows of FDI in authoritarian countries. Additionally, larger markets (ie, larger populations) are associated with greater FDI inflows. Surprisingly, rule of law is not consistently statistically significant in the full models, although it is positive and significant in the base models, as expected. This result may be because rule of law is collinear with other independent variables (like life expectancy and GDP per capita), thus not being a valid predictor of FDI inflows in the full models.

Further, to test the validity of my theoretical arguments I estimate the effect of BITs and PARCOMP and their interaction on the level of political risk and rule of law in authoritarian countries. This regression analyzes if BITs and citizen participation do lower political risk and 
increase property right security in authoritarian countries. Political risk is measured as total political risk according to the International Country Risk Guide (Political Risk Services 2011). ${ }^{33}$ Political risk is scaled from 0 to 100 with high values indicating low risk and low values indicating high risk. Table 13 in Appendix C provides the estimation results. As expected, BITs*PARCOMP interaction is positive and statistically significant in predicting both the rule of law and (low levels of) political risk.

\subsection{ROBUSTNESS CHECKS}

I conduct several robustness checks. First, I estimate the model using alternative specifications of the dependent variable, sample (all developing countries, resource rich countries excluded, polity classification of authoritarianism, FDI inflows by sector, imputed data), and methods of regression analysis ${ }^{34}$. To begin, I substitute FDI as a percent of GDP for inflows of FDI in current US dollars (logged) as the independent variable. The results remain consistent and statistically significant. See Table 14 in the Appendix C for model results. Then, I run the model excluding resource rich countries, measured as countries with oil and gas production greater than one hundred dollars per capita (Ross 2012). Similarly, the BIT*PARCOMP interaction is

${ }^{33}$ The Political Risk Services’ (2011) measure of political risk includes twelve components: Government stability, socioeconomic conditions, investment profile, internal conflict, external conflict, corruption, military in politics, religion in politics, law and order, ethnic tensions, democratic accountability, and bureaucracy quality.

${ }^{34}$ I do not estimate a model using bilateral FDI flows as this data has a very limited sample size (Neumayer and Spess 2005). In addition, between 1970 and 2011, the average outward FDI from the developed economies of the U.S., Western Europe, Canada, Israel, Japan, and Australia reached 90 percent of total worldwide FDI outflows (UNCTAD 2011b). Thus, since the overwhelming majority of FDI flows since 1970 have been from the developed world the need for bilateral estimation is reduced. 
positive and the conditional coefficients are statistically significant in predicting that at higher levels of PARCOMP, BITs are associated with greater inflows of FDI (base and medium models reveal a positive, statistically significant BIT*PARCOMP effect). The estimation results are in Table 15 and Figure 25 in Appendix C. Interestingly, the results are also robust on a sample of oil-rich countries only (see Table 16 in Appendix C). However, in the sample of the biggest oil producers (measured as the top half of authoritarian oil producers), this interaction is not statistically significant in predicting FDI inflows. Authoritarian leaders with extremely high levels of oil revenues will not be constrained by citizen input because they can use and distribute resource rents to thwart rebellion and maintain stability (column two in Table 16). ${ }^{35}$

Disaggregated FDI data contains a lot of missing data and therefore few observations for analysis. However, I run a base model of the effect of BITs*PARCOMP on FDI inflows to the three principal sectors: primary (natural resources, agriculture), secondary (manufacturing), and tertiary (services) (Mihalache-O’Keef and Li 2011). Results are robust for secondary and tertiary sectors, however the interaction is not statistically significant in predicting inflows of FDI in the primary sector (See Table 17 in Appendix C). A possible explanation for the insignificant primary sector results could be related to the rise in agricultural FDI for food security purposes (Braun and Meinzen-Dick 2009). Because of the need for food production, foreign firms and governments will accept the most economically lucrative deal that is quickest to negotiate (as opposed to the most secure) when investing abroad. Deininger and Byerlee’s (2011) World Bank

${ }^{35}$ In many resource-rich nations, income from natural resources is not sufficient to cover all government expenses or provide ample material concessions to appease the public (Chua 2003, Baunsgaard et al 2012, Collier et al 2010). Thus, citizen participation can and does constrain authoritarian leaders with resource rents. 
report on farmland corroborates this finding that FDI in agriculture flows to countries with weak governance infrastructures.

Regression results are robust for additional alternative sample sets: see Table 18 in Appendix C for results using polity classification of authoritarianism and Table 19 in Appendix C for results on the sample of all developing countries (please see footnote 32 for an explanation of estimation on sample of all developing countries $)^{36}$. Finally, I estimate the model using a fixed effects regression (as opposed to a panel regression including country dummies in the main model). Table 20 in Appendix C reveals a positive and statistically significant effect of bilateral investment treaties and citizen participation on FDI inflows in the base, medium, and full models.

Next, to further increase confidence, I create five imputed datasets using Amelia II (Honaker, King, and Blackwell 2012) and run estimations on the stacked datasets following the Rubin's (1987) combination rules. I run a random-effects regression on a balanced dataset of authoritarian countries (all countries who have never been considered democratic) for the BITs*PARCOMP and BITs*Freedom of Assembly interaction base and full models ${ }^{37}$. Table 21 in Appendix C provides the results. Although the BITs*PARCOMP interaction is not statistically significant, the conditional coefficients show a positive and statistically significant effect: the marginal effect of BITs is greatest in countries with high levels of citizen participation. The freedom of assembly regression results are robust.

${ }^{36}$ The results are also robust upon the exclusion of China (an outlier) from the sample.

${ }^{37}$ Please note that I must use a balanced dataset when using the multiple imputation estimation commands in STATA. I chose to highlight the random effects regression results because the fixed effects regression results are not robust (for models with inflows of FDI in current U.S. dollars (logged) as the dependent variable). However, the fixed effects regression results are robust for models with inflows of FDI as a percent of GDP as the dependent variable. 
Second, I further address issues of endogeneity by running a dynamic panel model, an instrumental variable model, and a selection model (see Simmons 2010 for endogeneity concerns associated with research on international treaties). The primary concern is reverse causality of inflows of FDI influencing the number of BITs in force and level of citizen participation. However, it is important to note that the possible endogeneity could be causing an underestimation of the true causal effect. For example, as a country received greater inflows of FDI it has less need to sign more bilateral investment treaties. Thus, the effect of FDI on BITs is negative. Similarly, the effect of FDI inflows increasing exclusionary politics is supported in the dependency literature (see Evans (1979), for example).

However, in order to thoroughly address issues of endogeneity, I first use the ArellanoBond method to estimate the variation of FDI in authoritarian regimes ${ }^{38}$. The independent variables of interest, BITs and PARCOMP are considered endogenous in this estimation. In these models, I fail to reject no second order autocorrelation and the Sargan test for over-identifying restrictions, thus fulfilling the Arellano-Bond assumptions of no autocorrelation in the idiosyncratic errors and a weak relationship between the instruments and error term. See Table 22 in the Appendix for estimation results, the interaction of BITs and PARCOMP is positive and statistically significant in the base models indicating that at high levels of citizen participation, BITs are associated with greater inflows of $\mathrm{FDI}^{39}$.

${ }^{38}$ The Arellano-Bond estimation also addresses issues of temporal dependence by including a lagged dependent variable (FDI inflows) as an independent variable.

${ }^{39}$ In the full model estimation, BITs*PARCOMP is not statistically significant (however, the coefficient is in expected direction) in predicting FDI inflows to authoritarian regimes. However, the Arellano-Bond estimation results are robust for the full model (and base models) in the developing country sample. 
I also estimate an instrumental variable model to further account for endogeneity (Table 23 in Appendix C). Following Rosendorff and Shin (2011), I use the number of United Nations Educational, Scientific, and Cultural Organization (UNESCO) conventions in force as the instrument for bilateral investment treaties (UNESCO 2013). Rosendorff and Shin (2011) argue that UNESCO conventions are a good instrument as they indicate a country's willingness to participate in international law relationships, but the conventions are not related to FDI inflows and thus should not impact FDI flows to the signatory. To instrument for citizen participation, I use public health expenditures as a percent of GDP. Public health expenditures are associated with the welfare-enhancing policies pursued by leaders in regimes with high levels of citizen participation (citizen participation and public health expenditures are positively correlated in authoritarian countries). However, the level of public health expenditures is not highly correlated with inflows of FDI (correlation is close to zero). Research indicates that educational skills, not the level of healthcare, is a the most important aspect human capital for attracting FDI flows (Noorbakhsh et al 2001). Additionally, I include another instrument for citizen participation: women's political rights from the Cingranelli-Richards Human Rights Dataset, which contains measures that proxy for citizen participation: the right of women to petition government officials and join parties. This variable also assesses women's right to vote and hold political positions. Women's political rights and citizen participation are positively correlated (0.3), while the correlation between women's political rights and inflows of FDI is small (less than 0.1) in authoritarian countries. Blanton and Blanton (2011) is the first working paper to assess how women's political and economic rights attract inflows of FDI to developing countries and they find mixed and contradictory results. Thus, I argue that women's political rights is not a strong indicator of FDI inflows. The results of the instrumental variable regression show a robust 
positive and statistically significant effect of BITs*PARCOMP (instrumented) on inflows of FDI to authoritarian countries. Unfortunately, my model does not meet the parameters for underidentification or strong identification as I fail to reject the Kleibergen-Paap statistic of having fewer true instruments than endogenous variables and I fail to reject the Kelibergen-Paap F statistic of weak instruments. However, I do fail to reject the Hansen J Statistic of overidentification. Additionally, it is important to note that the endogeneity test (equivalent to Hausman test statistic) shows that both bilateral investment treaties and citizen participation are not endogenous in the regression ${ }^{40}$.

Then, following Rosendorff and Shin (2011), I estimate a selection model for selection into signing bilateral investment treaties. In the two stage least squares regression, the dependent variable in the first stage is a dummy variable for signing a bilateral investment treaty, while the second stage's dependent variable is FDI inflows. In the first stage, the number of UNESCO conventions is the instrumental variable for signing a bilateral investment treaty (taken from Rosendorff and Shin 2011, see above). Following Rosendorff and Shin (2011), I also control for preferential trade agreements (PTAs), government stability, GDP growth, and GDP per capita in the selection equation. Table 24 in Appendix C highlights the positive and statistically significant effect of UNESCO conventions predicting signing a BIT in the first stage and then the robust results of the BITs*PARCOMP interaction in predicting FDI inflows in the second stage.

Third, I control for additional variables (time trend, international factors, corruption, labor rights, and conflict) in order to account for all key determinants of FDI and to address alternative hypotheses. In the past decades, the number of BITs signed has increased significantly. To account for this trend, I include a time trend variable in my analysis. Results are

${ }^{40}$ Please note that this test may not be valid as the instruments are considered weak. 
robust. Additionally, I control for international factors that could attract foreign investors to developing countries: capital account openness (Chin and Ito 2008) and foreign aid (World Bank 2011). Integration in the international system and level of foreign aid are positively correlated with FDI inflows. My hypothesis that BITs*PARCOMP effectively predict FDI inflows remains robust. A final control variable of interest is conflict- as war or civil strife may deter foreign investment. I control for the level of internal conflict, which captures civil war, coup threats, terrorism, political violence, and civil disorder (Political Risk Services 2011). Conflict is not statistically significant in predicting FDI inflows, ceteris paribus. Table 25 in the Appendix C presents these results.

In order to address the alternative hypotheses that corruption and lax labor laws attract foreign investors by 'greasing the wheel' and decreasing labor strikes and protests, respectively, I run my main model including control of corruption and workers rights as control variables. Table 25 in the Appendix C indicates robust results for the BIT*PARCOMP interaction, while control of corruption and workers' rights have an insignificant effect on FDI to authoritarian regimes.

Next, I test the alternative hypothesis that the strength of enforcement procedures dictated by the BITs in force is a key determinant of FDI inflows to authoritarian countries. Allee and Peinhardt's (2010) data indicates that the strength of enforcement procedures are weaker in authoritarian regimes and thus could be associated with increased noncompliance by the authoritarian leader. I estimate the base and full models including total BITs in force multiplied by the average strength of enforcement procedures (scaled 0 to 3 with higher values indicating stronger provisions). See Table 26 in the Appendix for regression results. Although the 
interaction term is positively signed, it is not statistically significant. ${ }^{41}$ Thus, the strength of enforcement procedures specified in BITs does not significantly influence FDI inflows to authoritarian countries. A key implication of these results is that compliance to international treaties is determined primarily by domestic conditions within the signatory.

Finally, I test the alternative hypothesis that formal political institutions attract foreign investment to authoritarian regimes. For example, Gandhi (2008) argues that institutionalization in authoritarian regimes leads to greater stability in policy-making, which is attractive to investors (144). The formal institution independent variables of interest are PARREG, which measures the degree of organization and institutionalization of participation, the number of political parties in legislature, the mode of legislature selection, and the number of veto players (Cheibub et al 2009, Marshall and Gurr 2008, Henisz 2000). Chart 2 in Appendix B contains all variable descriptives. See Table 6 and Figure 14 below for estimation results.

Table 6 Determinants of FDI Inflows to Authoritarian Countries: Formal Political Institutions

\begin{tabular}{|c|c|c|c|c|c|c|}
\hline & (1) & (2) & (3) & (4) & (5) & (6) \\
\hline BITs in force & $\begin{array}{c}0.142^{* * * *} \\
(0.0352)\end{array}$ & $\begin{array}{c}0.0202 \\
(0.0254)\end{array}$ & $\begin{array}{l}-0.00664 \\
(0.0265)\end{array}$ & $\begin{array}{c}0.123^{* * *} \\
(0.0226)\end{array}$ & $\begin{array}{c}0.0289 * * * \\
(0.0101)\end{array}$ & $\begin{array}{c}0.0212 \\
(0.0178)\end{array}$ \\
\hline Legislature & $\begin{array}{c}0.552 * * \\
(0.241)\end{array}$ & $\begin{array}{l}-0.119 \\
(0.186)\end{array}$ & $\begin{array}{l}-0.188 \\
(0.183)\end{array}$ & & & \\
\hline BITs*Legislature & $\begin{array}{c}-0.0457^{* * *} \\
(0.0163)\end{array}$ & $\begin{array}{c}0.0124 \\
(0.0125)\end{array}$ & $\begin{array}{l}0.0204 * \\
(0.0123)\end{array}$ & & & \\
\hline PARREG & & & & $\begin{array}{c}0.174 \\
(0.218)\end{array}$ & & \\
\hline BITs*PARREG & & & & $\begin{array}{c}-0.0261 * * * \\
(0.00748)\end{array}$ & & \\
\hline Veto Players & & & & & $\begin{array}{l}-0.0123 \\
(0.274)\end{array}$ & \\
\hline BITs*Veto Players & & & & & $\begin{array}{c}0.0122 \\
(0.0177)\end{array}$ & \\
\hline
\end{tabular}


Parties

$-0.0397$

(0.187)

BITs*Parties

0.00811

(0.00872)

Rule of Law

$0.986 * * * \quad-0.0106$

$-0.360$

$-0.117$

$-0.398$

$-0.379$

Log Population

(0.148)

(0.333)

$0.621^{* * *}$

4.638***

(0.381)

(0.209)

(0.387)

(0.388)

(0.132)

(0.875)

2.933***

$2.466 * * *$

2.466***

$2.892 * * *$

GDP Growth

0.00966

(0.868)

(0.679)

(0.746)

(0.885)

(0.00755)

$-0.00223$

0.00411

6.58e-05

9.78e-06

Life Expectancy

$0.0957 * *$

(0.00915)

(0.00880)

(0.00963)

(0.00958)

(0.0411)

0.0713

$0.0754^{* *}$

0.0718

0.0702

Oil Rent (\% GDP)

(0.0445)

(0.0315)

(0.0446)

(0.0438)

$-0.0193^{* *}$

$-0.0214^{* *}$

$-0.0192 * *$

$-0.0180 * *$

(0.00885)

(0.00890)

(0.00866)

(0.00909)

Inflation

1.05e-05

2.11e-05

8.03e-06

8.45e-06

(5.41e-05)

(5.10e-05)

(5.45e-05)

(5.44e-05)

Log GDP per capita

$0.861^{* * *}$

$0.798^{* * *}$

$0.880 * * *$

$0.852 * * *$

(0.206)

(0.134)

(0.199)

(0.204)

0.997

$-2.460 *$

$-4.522 * * *$

0.949

(1.209)

(1.342)

(1.256)

(1.161)

Country Fixed Effects

No

Yes

Yes

\section{Yes}

Yes

Yes

Decade Dummies

Yes

Yes

Yes

Yes

Yes

Yes

Observations

682

661

548

511

539

548

R-squared

0.974

0.988

0.984

0.991

0.984

0.985

Number of countries

88

76

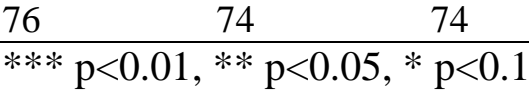

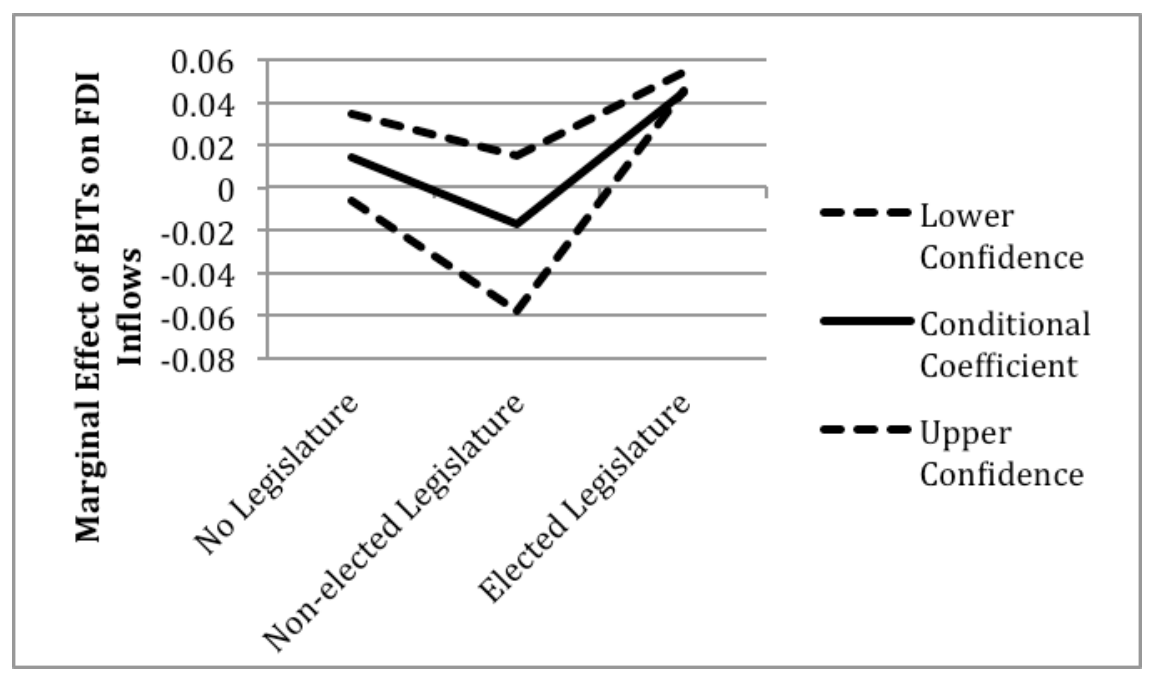

Figure 14 Marginal Effect of BITs on FDI Inflows (Conditional on Legislature) 
Table 6 highlights that formal institutions do not attract FDI inflows to authoritarian countries with BITs. Veto players and political parties fail to be statistically significant in attracting FDI to authoritarian regimes with BITs in force ${ }^{42}$. The legislature is inconsistent in attracting FDI to authoritarian regimes with BITs in force. In fact, the Figure 14 above highlights how the positive and statistically significant result of legislature*BITs is not robust. The marginal effect of BITs attracting FDI to authoritarian regimes is not statistically significant in regimes with differing modes of selection in the legislature. Further, the PARREG*BITs interaction is negative and statistically significant. This result suggests that in authoritarian countries with BITs greater institutionalized political participation is associated with less inflows of FDI. Perhaps, foreign investors view the formal institutions as constraints to achieving their preferred policies ( $\mathrm{Li}$ and Resnick 2003). Overall, my results reveal that foreign investors do not value formal institutions as a means to secure their property in authoritarian regimes.

As an additional check, I estimate the model including both formal political institutions and informal citizen participation and their interaction with BITs in force. Table 27 in Appendix C presents the results. The first regression highlights the robustness of my variable of interest, the interaction of BITs and citizen participation, after the inclusion of the veto player and political parties covariates. In the next two regressions, BITs*PARCOMP interaction is positive and statistically significant, while BITs*Veto Players and BITs*Parties are not statistically significant.

${ }^{42}$ Please note that the conditional coefficients for veto players and political parties are statistically significant. However, the marginal effect of BITs on FDI inflows is significantly smaller at the highest levels of veto players and political parties ( 0.041 and 0.037 respectively) compared to the highest level of citizen participation (0.064, see Figure 13 above). Additionally, research suggests that the interaction term's statistical significance is the critical value in explaining model significance (see Brambor, Clark, and Golder (2006), for example). The marginal effects for PARREG models are not statistically significant. 


\subsection{SUMMARY OF RESULTS}

Overall, the empirical results provide strong evidence in support of the hypothesis that authoritarian countries with bilateral investment treaties and high levels of citizen participation attract the most foreign direct investment inflows. BITs play a critical role in signaling a will to pursue liberal economic policies, while citizen participation ensures stability to these FDI friendly policies. Countries with few BITs and/or low levels of citizen participation are not as successful in attracting FDI inflows. The estimation results are robust to alternative specifications of the dependent and independent variables, additional controls, and different samples and regression methods. In fact, the BITs*PARCOMP interaction remains positive and statistically significant in predicting FDI even after controlling for formal political institutions, such as the political parties in the legislature or number of veto players.

Ultimately, this analysis builds on Chandra and Rudra (2011) to show the effectiveness of citizen participation in reducing erratic and opportunistic decision-making by authoritarian leaders on policies related to foreign direct investment. The results provide further support that informal citizen participation, as opposed to of formal political institutions, is the key indicator of constraints on authoritarian leaders. 


\subsection{CASE STUDY: JORDAN AND SYRIA}

While conducting my survey of U.S. multinational companies, a respondent called me to tell me that he would "never invest in authoritarian countries." He said he wanted to emphasize to me the risks of investing in authoritarian countries. He further explained that his father was commissioned by the Syrian government to invest in the country. His father took the opportunity and spent much time and resources developing and starting production in Syria. However, after several years of production, the Syrian government expropriated the land and the respondent's father's company lost their venture and a lot of capital. Although the Syrian government itself called for foreign investment, the lack of constraints on the leadership ultimately led to tremendous losses for the multinational company.

The FDI data highlights this risk of investing in Syria: despite Syria’s large population and oil reserves, it receives below average inflows of FDI for the Middle Eastern and North African region (Stevenson 2010). However, many of Syria's authoritarian neighbors have been quite successful in attracting FDI inflows: Egypt, Lebanon, Jordan, and Tunisia all receive above

average inflows of FDI for the region (Stevenson 2010). This chapter presents a case study of Syria and Jordan to illustrate the tenants of my theory-authoritarian countries that signal FDI friendly policies and have high levels of citizen participation attract the most FDI inflows.

Following Gerring (2007), I conduct a most-similar case research design to illustrate and analyze the foundations and causal mechanisms of my theory. The most similar system case 
study methodology is taken from Przeworksi and Tuene's The Logic of Comparative Social Inquiry (1970) and John Stuart Mill's method of difference (Skocpol and Somers 1980). Przeworski and Tuene (1970) explain that in the most similar systems design, "Common systemic characteristics are conceived of as 'controlled for,' whereas intersystemic differences are viewed as explanatory variables” (33).

Specifically, Jordan and Syria have similar levels of economic development (measured by GDP per capita and life expectancy) and both are located in the Middle East and North Africa (MENA) region. Additionally, Jordan and Syria have signed comparable numbers of bilateral investment treaties- 32 and 24 respectively. Both countries have thus made concerted efforts to signal to the international community that they wish to attract foreign investment. However, Jordan and Syria differ on one key aspect: citizen participation. While Jordan allows high levels of citizen participation (among the highest among authoritarian countries), Syria greatly represses citizen participation and ranks among the lowest of authoritarian countries. However, in regards to formal political institutions, both Syria and Jordan have elected legislatures with multiple parties (Cheibub et al 2009). Table 7 below summaries this data and the most similar design $^{43}$. The outcome variable, FDI inflows, also differs between the two countries with Jordan leading in attracting FDI ${ }^{44}$.

${ }^{43}$ Please see the empirical chapter and Appendix D for data descriptions and sources.

${ }^{44}$ Please note that one big difference between Jordan and Syria is that Syria contains vast oil resources. The value of oil and gas production per capita in Syria in 2008 was 763 dollars, compared to 12 dollars per capita in Jordan (Ross 2012). Ultimately, this fact further contributes to the strength of my argument—despite Syria's oil, it fails to attract investment; while resourcepoor Jordan remains successful in attracting high levels of FDI. 
Table 7 Jordan and Syria Comparison

\begin{tabular}{|l|c|l|l|l|l|l|l|l|}
\hline & PARCOMP & BITs & $\begin{array}{l}\text { GDP } \\
\text { per } \\
\text { capita }\end{array}$ & $\begin{array}{l}\text { Life } \\
\text { Expectancy }\end{array}$ & Legislature & Region & $\begin{array}{l}\text { FDI } \\
\text { Inflows } \\
\text { (\% } \\
\text { GDP) }\end{array}$ & $\begin{array}{l}\text { FDI Inflows } \\
\text { (logged) }\end{array}$ \\
\hline Jordan & $\mathbf{4}$ & 32 & 8.3 & 73 & $\begin{array}{l}\text { Elected, } \\
\text { Multiple } \\
\text { Parties }\end{array}$ & MENA & $\mathbf{1 2 . 4 5}$ & $\mathbf{2 , 8 0 0 , 0 0 0 , 0 0 0}$ \\
\hline Syria & $\mathbf{1}$ & 24 & 7.9 & 75 & $\begin{array}{l}\text { Elected, } \\
\text { Multiple } \\
\text { Parties }\end{array}$ & MENA & $\mathbf{2 . 7 9}$ & $\mathbf{1 , 5 0 0 , 0 0 0 , 0 0 0}$ \\
\hline
\end{tabular}

This case study analysis seeks to investigate how two countries with similarly high levels of BITs in force, but differing levels of citizen participation attract (or deter) FDI inflows. As such, this comparison fits in the first two vertical boxes of the hypothesis matrix discussed in the empirical chapter:

Table 8 Citizen Participation and BITs in Force in Jordan and Syria

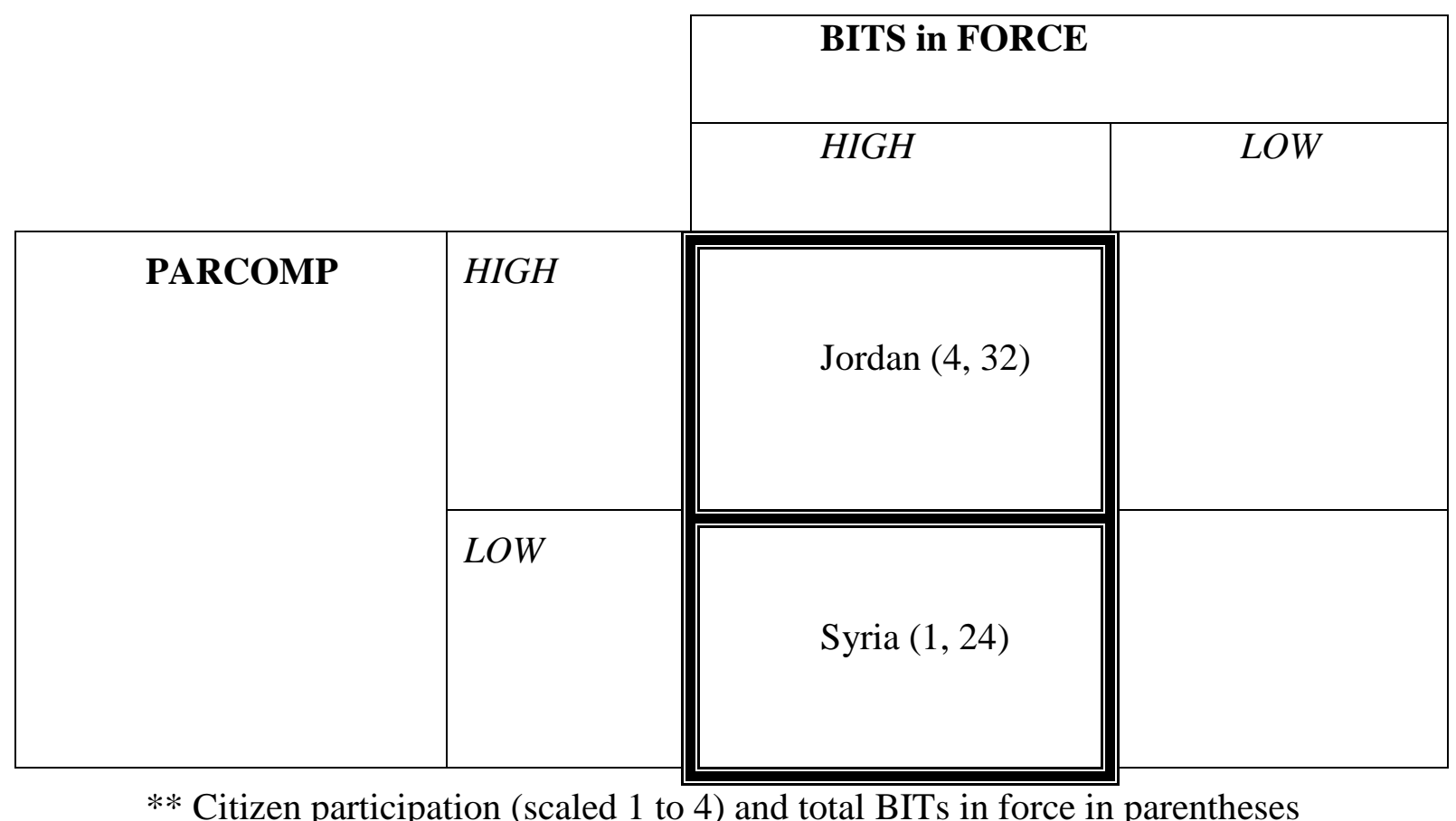

Ultimately, this case study will illuminate the declaration of FDI friendly policies by both the Jordanian and Syrian governments, while highlighting how Jordan's government incorporated 
and listened to the wider populous on these economic issues and Syria's government acted with little societal input. Jordan has continued to advance FDI friendly policies domestically, while the Syrian government's rhetoric has been largely superficial. The unconstrained behavior of the Syrian government has deterred FDI inflows, whereas Jordan's embrace of civil society has attracted and sustained foreign investment (and liberal economic policies) in the country. In the end, the raw data on the key variables of interest (bilateral investment treaties, citizen participation, and foreign direct investment inflows) reveal a similar story.

\subsection{DECLARATION AND PUBLICATION OF FDI FRIENDLY POLICIES}

Both the Jordanian and Syrian governments have signed bilateral investment treaties ${ }^{45}$ and publically declared a desire to attract foreign direct investment. Both Jordan and Syria have signed bilateral investment treaties with their neighbors (Algeria, Bahrain, Egypt, Lebanon, Morocco), the emerging developing economies (China, India, Indonesia, Russia), and the developed world (France, Germany, Greece, Italy, Spain, Switzerland) (UNCTAD 2011). The breadth of the signatories highlights the desire of both governments to signal a commitment to attracting FDI to the wide international audience and a diverse group of multinational companies. Figure 15 below graphs the rise in BITs signed by both nations.

45 According to Alle and Peinhardt (2010), the (data available) BITs signed by Jordan and Syria specify the ICSID in their legal provisions. 


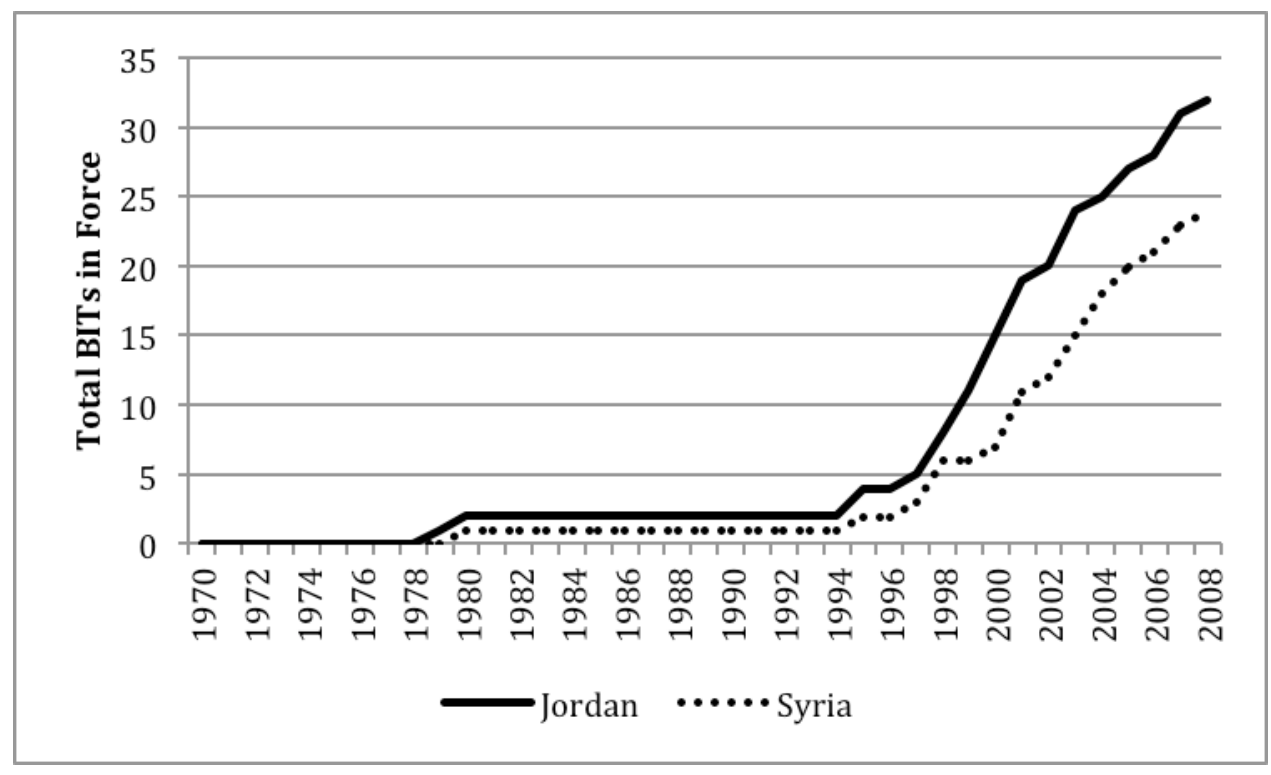

Figure 15 BITs in Force in Jordan and Syria

The signing of the BITs by Jordan and Syria has been publicized in the international media in sources such as the Baltic News Service, The Business Times Singapore, The Times (London), and the BBC. For example, in the Straits Times (Singapore), King Abdullah II heralds the signing of the investment treaty with Singapore and indicates that "The way the Singapore Government has been able to address reform and come from where it was many years ago to where it is now was really for us an example” (“Jordan King Hails FTA with S'pore” 2004). Thus, the international community is well informed of both governments' international commitments to attracting FDI inflows.

In addition to signing BITs, Jordan and Syria have both embraced and championed liberal economics in their local political rhetoric. These domestic choices highlight the outward desire of the regimes to embrace the liberal economic policies of the international investment treaties and to signal this choice to their domestic constituents. In Jordan, King Hussein chartered a path in support of world trade, finance, and investment in 1989 and King Abdullah II further pushed for liberalization reforms during his first years as leader in the early 2000s by calling for an 
improved investment environment and greater openness to the world (Milton-Edwards and Hinchcliffe 2009: 78, 89). For instance, Stevenson (2010) elucidates King Abdullah II’s commitment to liberal economics:

Since 1999 and the coming to the throne of King Abdullah, developing the country's domestic economic potential and improving its living standards have become the main policy priorities. The aim of the government is full implementation of a market economy and full integration in the world market... Acknowledgement of the role of the private sector as a main partner in economic activity was confirmed in the government's National Social and Economic Development Plan 2004-2006 (225).

The National Social and Economic Development Plan, also known as the National Agenda, presented Jordan's goals and strategies in regards to economic development and reconstruction. Primary targets included increasing GDP growth, per capita income, employment, women's employment, and foreign direct investment inflows and decreasing debt and poverty (Stevenson 2010: 225). The National Agenda was conceived in three phases involving promoting laborintensive industry, investing in infrastructure and governance, and liberalizing markets (Stevenson 2010: 225).

Similarly, the Syrian government began implementing liberalizing policies after the collapse of the Soviet Union (its major trading partner). Beginning in the late 1980s, Hafez alAssad started to advance economic liberalization, including liberal investment policies (Haddad 2012, Stevenson 2010). For example, in 1991, the Investment Law No. 10 was enacted, which intended to attract inward investments (Haddad 2012: 125-126). Also, the regime offered incentives to foreign manufacturing companies in order to further privatization efforts in that sector (Stevenson 2010: 278). Then, Bashar al-Assad called for further liberalization and economic progress in the beginning of his tenure (Haddad 2012, George 2003). In his inaugural address, Bashar al-Assad called for 
Steady, yet gradual, steps towards introducing economic changes through modernizing laws, removing bureaucratic obstacles to the flow of domestic and foreign investments, mobilizing public and private capital and activating the private sector and giving it better business opportunities (George 2003: 160).

Thus, the Syrian government has also publically declared a desire to advance liberal economic policies throughout the last two decades. However, the actual implementation of these liberal economic policies since the end of the Cold War has been minimal ${ }^{46}$ (Wacziarg and Welch 2008, Hinnebusch 2012, Haddad 2012). For example, the Investment Law No. 10 is considered a “loner" law as no additional reforms complemented this initial law (Haddad 2012: 132). As a result, obstacles to investment, such as regulations, remained high within Syria (Haddad 2012).

Ultimately, both the Jordanian and Syrian governments signaled to the international community their dedications to attracting FDI inflows through signing bilateral investment treaties. These signals were representative of a desire by the regimes to pursuing liberal economic policies (as is seen in the domestic policies and/or official speeches in both countries).

\subsection{DIFFERENCES IN CITIZEN PARTICIPATION}

Although Jordan and Syria have chartered similar paths in regards to publically embracing liberalization and foreign investment, they differ drastically in their domestic institutional environments supporting these policies. Jordan experiences high levels of citizen participation and civic activism (Milton-Edwards and Hinchcliffe 2009), whereas Syria remains very

\footnotetext{
${ }^{46}$ Haddad (2011) describes the limited economic reform advocated and implemented by Bashar al-Assad. He announced a plan for a "Social Market Economy" in 2005 that would involve significant economic reform - the Syrian Investment Agency was created and new investment law were passed shortly after (Haddad 2011). However, overall, Syria remains closed, heavily regulated, and dominated by crony capitalism (Haddad 2011, Donati 2012).
} 
repressive of participatory politics and is described as a "police state" by many scholars (MiltonEdwards and Hinchcliffe 2009, George 2003). The data on citizen participation (measured by PARCOMP scaled from one to five) highlights this difference:

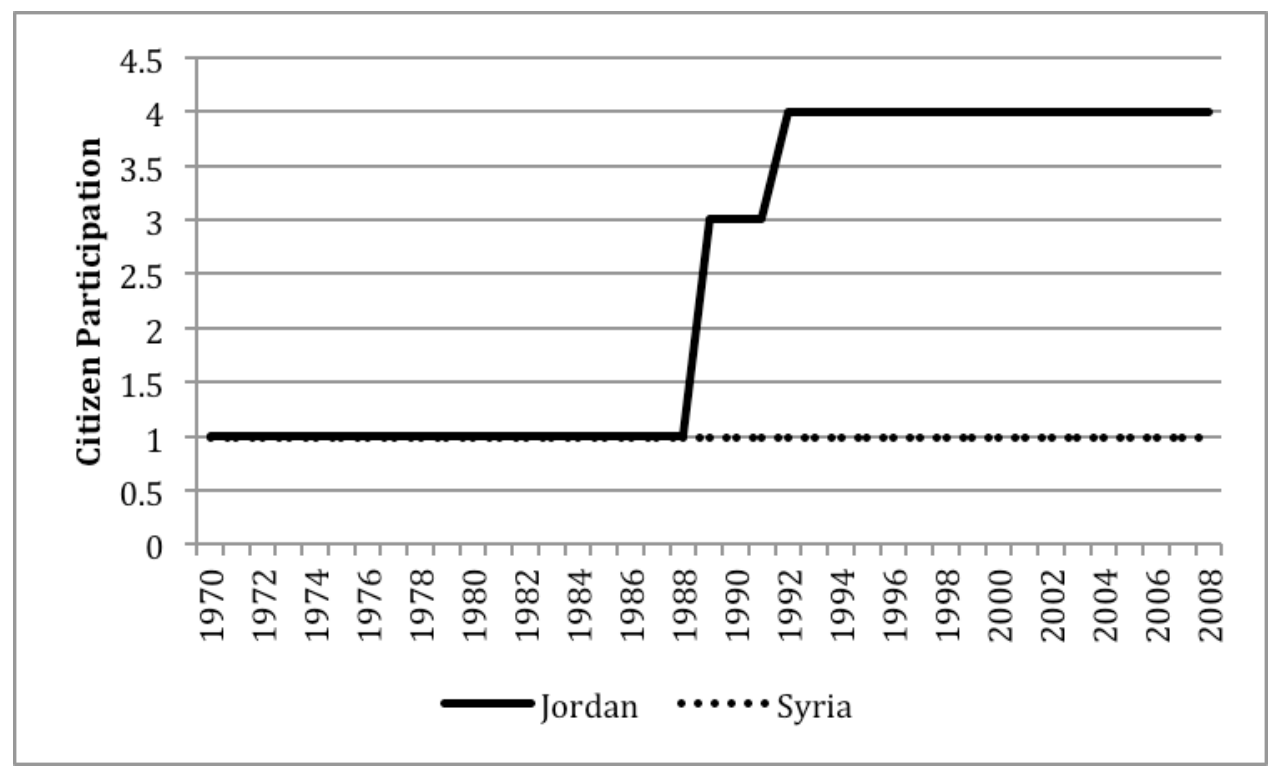

Figure 16 Citizen Participation in Jordan and Syria

Figure 16 indicates that Syria has remained at the lowest level of citizen participation (PARCOMP value of one) during the past forty years while Jordan's level of citizen participation increased in the early 1990s and is now relatively high (PARCOMP value of four).

In 1989, Jordan embarked on a path of political liberalization that involved a significant increase in popular participation and the freedom of assembly (Milton-Edwards and Hinchcliffe 2009, Ryan 2010) ${ }^{47}$. Although this political liberalization involved the formation and strengthening of formal institutions and processes (ie, elections), these formal institutions in

${ }^{47}$ Please note that despite the relatively high levels of citizen participation and freedom of assembly in Jordan compared to other authoritarian countries, there still exists limits on participation and associational activity (Milton-Edwards and Hinchcliffe 2009, Wiktorowicz 2000, Ryan 2010). 
Jordan do not aptly capture constraints on the King. In fact, Baaklini, Denoeux, and Springborg (1999) clarify that,

Since 1989, it (the parliament) has become a more credible, representative, and influential institution. Still, serious constitutional, political, and internal hurdles continue to prevent it from enjoying the prerogatives and from performing a range of functions that are appropriate for a legislature in a democratic system (164-5).

The parliament is characterized by limited representation and low voter turnout and the public has little confidence in its capacities (Baaklini et al 1999).

Instead, this case study focuses on the flourishing of informal citizen participation in decision-making in Jordan in 1989 and its further strengthening over time. For instance, Ryan (2010) explains,

Civil society has nonetheless continued to emerge in Jordan, especially in the wake of the political and economic liberalization process.... Beyond the numerous legal parties and professional associations within the kingdom, the key facets of Jordan's still-emerging civil society (as opposed to more explicitly political society) include many nongovernmental organizations within the kingdom (330).

Examples of Jordan's economic civil society organizations include the Amman Chamber of Commerce, Amman Chamber of Industry, Jordan Business Association (JBA), and the JordanU.S. Business Partnership (Carroll 2003).$^{48}$ In particular, the JBA has been an influential player in economic policymaking with the government since its founding in 1985 (Knowles 2005: 74) ${ }^{49}$. The JBA communicates with both the government and foreign investors in order to promote and maintain a favorable business environment for private enterprises (Knowles 2005:

\footnotetext{
${ }^{48}$ In addition, the semi-state institutions of the Jordan Investment Corporation and Jordan Investment Promotion Office were established to attract private investment (Knowles 2005: 52). Furthermore, professional and employer organizations and nongovernmental organizations are active throughout Jordan (for example, see http://www.civilsociety-jo.net/en/ and Ryan 2010) ${ }^{49}$ Carroll (2003) describes the Amman Chamber of Commerce and Amman Chamber of Industry as "state-dictated channels that served more to provide the state with legitimation and information than to give the business community a voice" (152). Instead, the JBA was the most influential and sovereign organization in the business sector.
} 
74-75, Carroll 2003: 151). Carroll (2003) explains the process of the JBA in public deliberation and policymaking,

The JBA held monthly meetings with key decision-makers (these were open to members and non-members); developed standing committees to address issues related to bilateral agreements and economic laws; and invited and hosted foreign delegations and individual potential investors (153).

The JBA also "negotiated directly with the executive branch of the government" (Carroll 2003: 151). Importantly, the policies advocated by the business community were productive, not rentseeking in nature —-they involved requesting greater participatory decision-making, bureaucratic reform, and sectoral assistance with competitiveness (Carroll 2003) ${ }^{50}$. Also, importantly, foreign investors and attracting foreign investment are priorities within the business community as highlighted in Carroll's (2003) description of the JBA's policymaking processes and in the establishment and success of foreign-local based organizations like the Jordan-U.S. Business Partnership.

There exists ample evidence that the Jordanian government actively involved and listened to the wider populous and these business interest groups when devising and establishing economic policies. First, scholars have cited primary evidence of government officials advocating inclusionary decision-making. For example, Carroll's (2003) interview research reveals,

${ }^{50}$ Moore (2000) discusses the weaknesses and unproductive activities of the business sector in Jordan. However, his analysis focuses on formal relationships between business and the parliament, such as lobbying and representation (Moore 2000: 188). In contrast to Moore, Carroll (2003) explains, "State and business have negotiated out their new relationship largely outside of Jordan's newly-active democratic institutions" (4). In this environment, business associations and other economic organizations have been strong and growing. In addition, Carroll's (2003) analysis of the productive policies of business associations follows the research by Doner and Schneider (2000) on the market supporting and complementing activities of business associations in the developing world. See footnote 20 for further details. 
State officials repeatedly stressed the need for business to reach a consensus within the community and to then bring that consensus to the state... officials believe that is businesspeople bring a common policy position to the state, then that policy is likely to... promote the good of the economy as a whole (164).

In particular, the Jordanian Director of Securities Exchange explained that the government needs input from the private sector in order to advance policies that are employment, growth, and welfare enhancing (Carroll 2003: 158).

Second, the National Agenda, involving key economic issues such as GDP growth, employment, FDI inflows, poverty, and debt was "developed in consultation with stakeholders from different sectors, civil society associations, and the public" (Stevenson 2010: 225). This National Agenda process amply highlights the participatory, inclusionary decision-making regarding economic affairs in Jordan (Stevenson 2010, Ryan 2010). The former foreign minister, Marwan Muasher, led the "broad-based" committee of both government and societal participants in drafting the National Agenda that ultimately advocated further strengthening of civil society (Ryan 2010: 332). This National Agenda represented a continuation of the liberal economic policies pursued throughout the 1990s and 2000s, thus highlighting the incremental nature of policymaking associated with governments with high levels of citizen participation. Also, the cornerstone of the National Agenda was liberal economic policies, underscoring the preferences of the citizens for such economic strategies.

In contrast to Jordan, Syria allows little civil society freedoms and has continued to repress civic activism in the past ten years (Stevenson 2010, George 2003, Carapico 2010, Lawson 2010). George (2003) explains that the Syrian government monitors and controls associational activity: Associations "are allowed to function in peace only to the extent that they do not impinge on the prerogatives of the regime- which in this police state leaves them with 
only smallest room for maneuver” (x). In fact, during the Damascus Winter ${ }^{51}$ in 2001, the Syrian regime imposed new and greater restrictions on the freedom of speech and assembly (Lawson 2010: 418).

Although business associations and networks exist in Syria, such as the Syrian Business Council, Chamber of Commerce, Syrian Enterprise and Business Centre and the Syria Young Entrepreneurs Association (Haddad 2012, Stevenson 2010), the environment is characterized as rife with crony capitalism (Donati 2012, Haddad 2012). Donati (2012) explains that in Syria, "liberalization and privatization ... work as instruments for co-opting and reorganizing networks of allegiance” (49). In particular, economic opportunities are distributed to businessmen close to the regime (George 2003: 160). As such, Haddad (2012) explains that the "Chambers are not (yet) taken seriously as representative institutions by prominent members of the business community" (108). The prevalence of patronage ties and mistrust between the government and economic community has hampered strong, productive relationships (Haddad 2012).

Ultimately, the Syrian leadership is unconstrained- the public and autonomous organizations play little to no role in decision-making (Haddad 2012: 18). Haddad (2012) elucidates the role of the Syrian government as a controller of the associations (as opposed to a facilitator of dialogue and communication):

The function of these institutions ... was not to aggregate the interests and demands of the business community for the purpose of formulating positive-sum policies that might benefit both business actors and the economy as a whole. Instead, their function was to circumscribe decision-making by limiting it to a small set of actors, not in accordance with what serves the economy, but rather in accordance with what serves whom... these are essentially top-down institutions that are governed primarily by regime, not by business rules (109).

51 The 'Damascus Spring' refers to a period of time in Syria (after Hafiz al-Assad's death in the spring of 2000) when civil society and public debate flourished. This movement was quickly repressed in the following 'Damascus Winter' in 2001. (George 2003) 
For example, within Chambers of Industry and Commerce in Syria, many of the board members are selected by the regime (Haddad 2012). In contrast to Jordan's National Agenda, the civil society organizations involved in Syria's Tenth Five Year Plan (2005-2010) (a framework for economic development and liberalization for Syria) were "closely linked to the regime" and ultimately "block(ed) the emergence of an autonomous civil society” (Donati 2012: 44). The emergence and involvement of government-connected organizations in economic policy was accompanied by strong repression of independent organizations (Donati 2012). In Syria, associational freedom is curtailed and associational independence limited. As indicated in the phone conversation with the survey respondent, this unconstrained executive branch is a strong deterrent for foreign investors investing in Syria.

\subsection{FDI INFLOWS TO JORDAN AND SYRIA}

Overall, the qualitative and quantitative evidence on Jordan and Syria indicate that Jordan will be most successful in attracting FDI inflows. In Jordan, the government publically signaled a dedication to attracting foreign investment and pursued participatory decision-making practices on economic policies. The inclusion of civil society and societal preferences in the economic policymaking ensured the stability of economically liberal policies over the past decades. In contrast, although the Syrian regime signaled a desire to attract FDI, the lack of constraints on the leadership is expected to result in a failure to attract high levels of foreign direct investment. Figure 17 depicts inflows of FDI to both Jordan and Syria since 1980. 


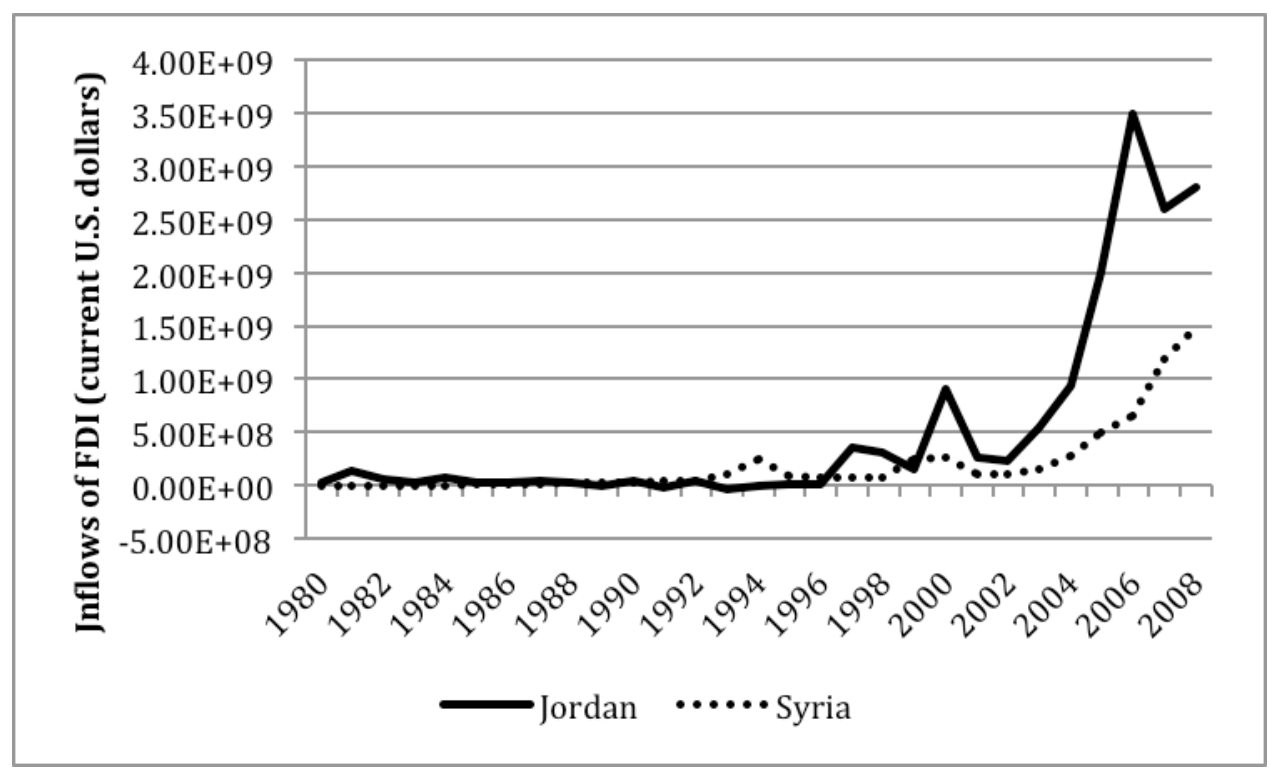

Figure 17 FDI Inflows to Jordan and Syria

As predicted, inflows of FDI to Jordan has increased tremendously since the government committed to liberal economics and allowed greater citizen participation (starting in 1989). On the other hand, Syria has been less successful in attracting FDI inflows. Most recently, in 2008, Jordan attracted nearly double the value of FDI inflows as Syria.

To further illustrate and synthesize the tenants my theory, Figures 18 and 19 below document the number of BITs in force, the level of citizen participation, and inflows of FDI in Jordan and Syria. As discussed, Jordan's FDI inflows begin to show a strong upward trend after it begins signing bilateral investment treaties and experiences an increase in citizen participation in the early 1990s. Despite the number of BITs in force, inflows to FDI to Syria remain fairly stagnant as citizen participation lags. 


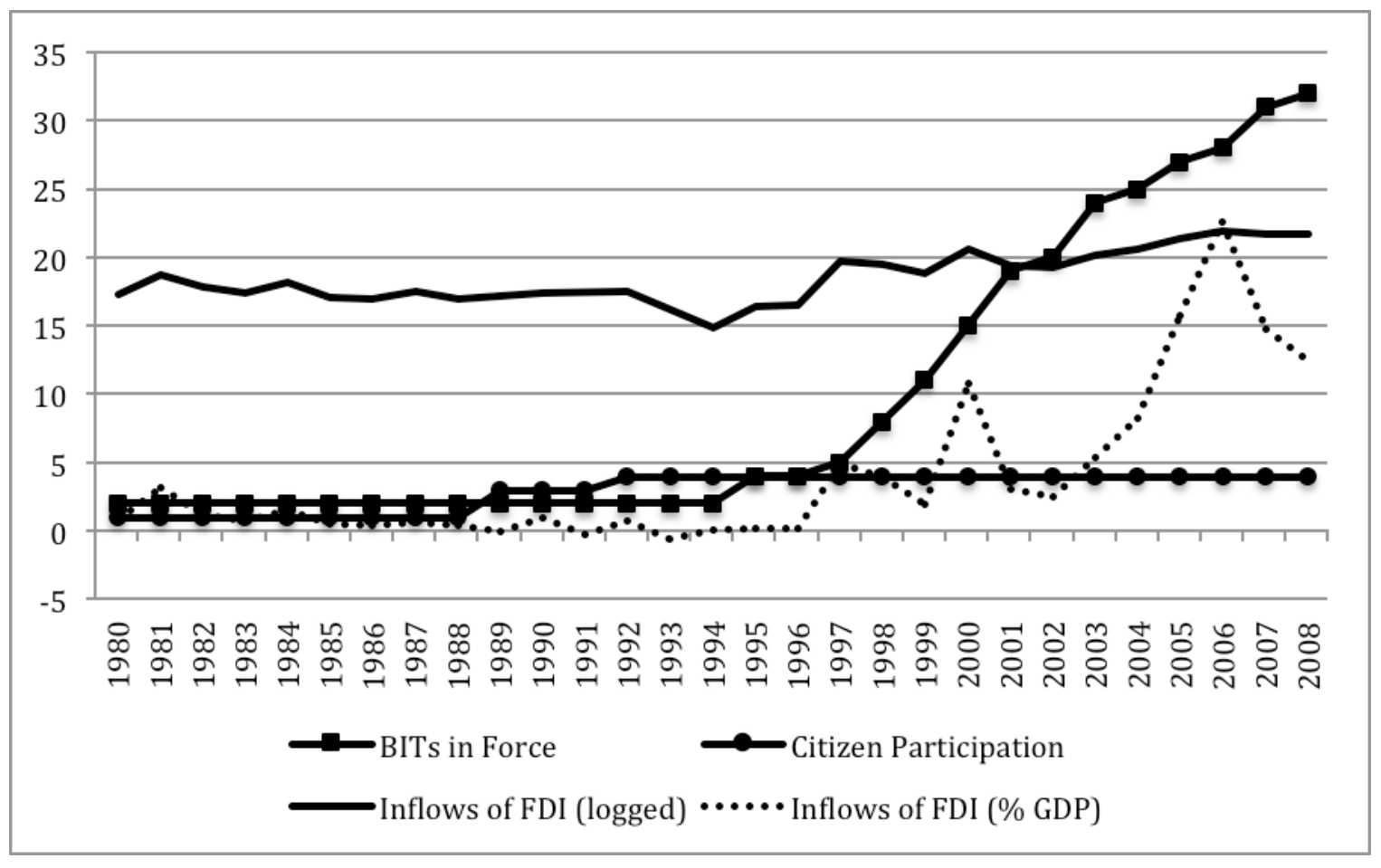

Figure 18 Determinants of FDI Inflows to Jordan

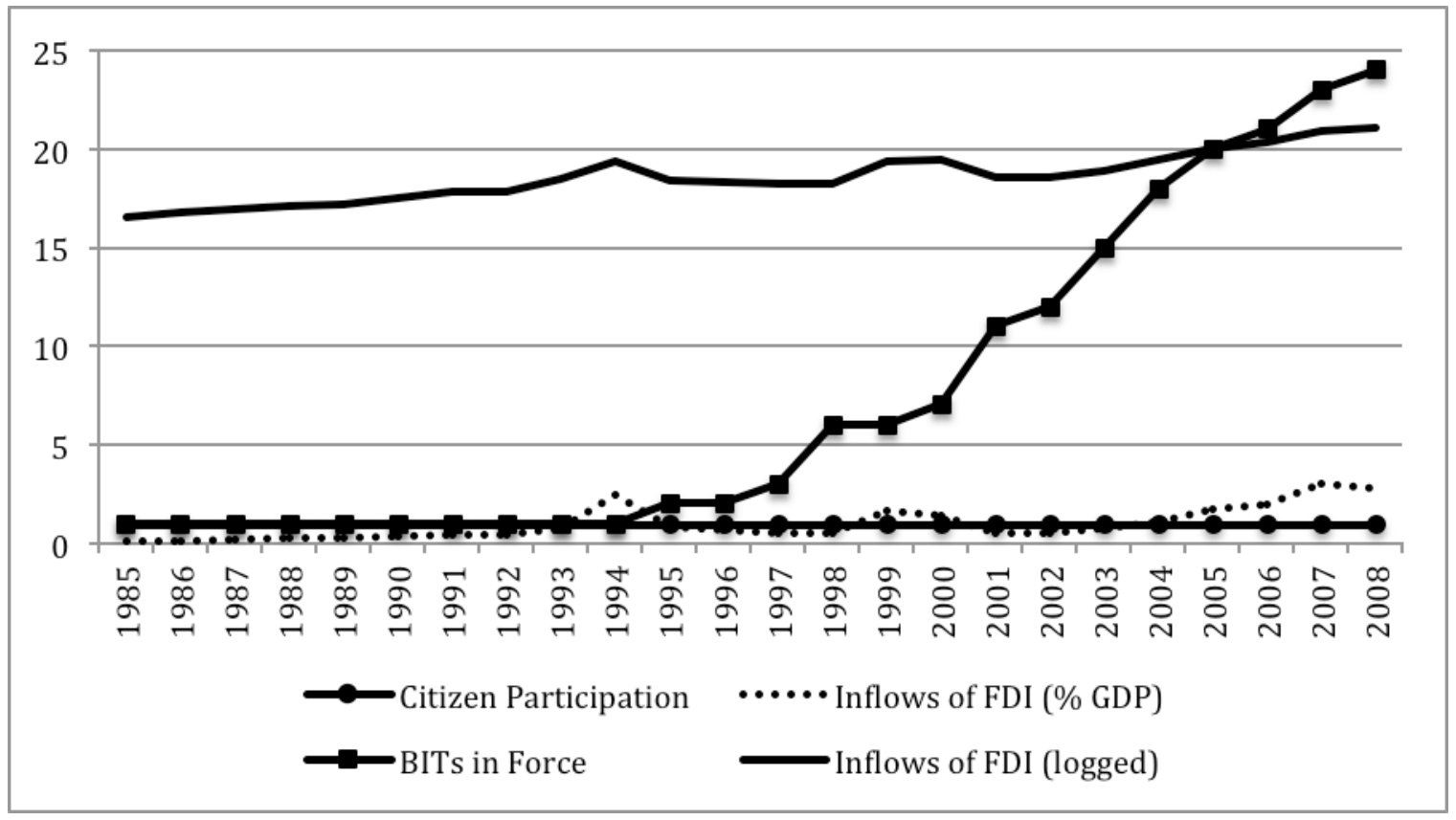

Figure 19 Determinants of FDI Inflows to Syria 
The data powerfully demonstrates the necessity of BITs and citizen participation in attracting FDI to authoritarian countries. Without domestic constraints on the authoritarian leader (as in Syria), bilateral investment treaties will be insufficient to attract the most FDI inflows to that country.

\subsection{SUMMARY AND IMPLICATIONS}

The survey respondent's story about his father's company in Syria aptly highlights the theory that authoritarian regimes that are constrained from above and below attract the most foreign direct investment inflows. Although the Syrian government continues to espouse FDI friendly policies, for example commissioning the respondent's father's company and signing bilateral investment treaties with countries across the globe, the lack of constraints on the leadership results in risk of noncompliance to these policies for the foreign investor. As the respondent's story revealed, expropriation and other violations of established liberal economic policies and institutions occur in authoritarian countries with exclusionary, repressive policymaking ${ }^{52}$. As a result, Syria has been unsuccessful in attracting FDI inflows. In contrast, Syria's neighbor, Jordan, has proved to be a strong destination for foreign direct investment. In Jordan, participatory politics have ensured a continued dedication to the government's declared commitment to FDI friendly policies.

Overall, the case study of Jordan and Syria underscore which authoritarian countries are most integrated in the global economy. This insight is important as participation in the

${ }^{52} \mathrm{Li}$ (2009a) does record an expropriation by the Syrian government between 1970 and 1990. Jordan does not have available data. 
international economic system has strong implications for global peace, prosperity, and cooperation. Further, analyzing and understanding citizen preferences, expectations, and experiences with FDI in authoritarian regimes paints a clearer picture on the direction of globalization in the future. 


\subsection{CONCLUSION}

Although scholars have determined that democracies are attractive destinations for FDI, many authoritarian developing countries are drawing greater inflows of FDI in the last decades. In fact, some authoritarian developing countries are attracting similar levels of FDI as democratic developing countries. This dissertation explains which authoritarian regimes have been successful in attracting these FDI inflows. Specifically, the role and interplay of domestic and international institutions in determining investment flows to authoritarian countries is examined. I argue that international investment treaties are necessary to attract FDI to authoritarian regimes because they signal a dedication to FDI friendly policies to the investor. However, an authoritarian regime's openness to citizen input plays a key role in ensuring compliance to the international agreement's terms. Under conditions of citizen participation, citizens can voice their preferences for FDI and strong property right protections; while, leaders in these regimes have an incentive to listen to citizens preferences as they maintain power through welfareenhancing, participatory policymaking. Thus, authoritarian regimes with international investment treaties and high levels of citizen participation will attract the most FDI.

Estimation results confirm both the theoretical foundations and formal hypothesis of this dissertation: citizens in authoritarian countries view FDI inflows as welfare-enhancing and authoritarian countries with bilateral investment treaties and high levels of citizen participation attract the most FDI inflows. Additionally, results from an original survey of U.S. foreign 
investors reveal that multinational companies are aware of and value international investment treaties and freedom of association in host nations, thereby providing key primary evidence in support of the hypothesis. Finally, a comparative case study of Jordan and Syria further illustrates the micro-foundations of the theory. While both Jordan and Syria have signaled a dedication to liberal economic policies, Jordan has been the successor in attracting FDI inflows because of its participatory decision-making processes.

\subsection{CHALLENGING CONVENTIONAL WISDOM}

In this dissertation, I question several predominant assumptions found in both the political science literature and colloquial channels. Below I list the key points discovered and verified in this analysis that challenge conventional wisdom.

\section{- All authoritarian countries are not necessarily high-risk environments for investors}

Classical political science research and current conventional wisdom amasses all authoritarian countries into one general category with little detail on the variation among different regimes in regards to political, economic, or social conditions (ie, Friedrich and Brzeinski 1961). Recently, the study and classification of authoritarian institutions is a hot topic in political science (Levitsky and Way 2002, Magaloni 2008, Gandhi 2008, Geddes 2003, Fang and Owen 2011, Rosendorff and Shin 2011). This dissertation contributes to this set of literature by uncovering how variation in domestic institutions and participation in international agreements of authoritarian countries influences FDI inflows to those nations. Although, overall, authoritarian countries have higher levels of political risk than democratic developing countries, some authoritarian countries have been able to reduce this risk and attract FDI inflows. 
- Some authoritarian leaders do listen to their citizens, especially on economic issues

In contrast to conventional wisdom, this analysis builds on Chandra and Rudra (2011) to highlight how some authoritarian leaders do listen to their citizenry, especially in regards to economic issues (which are less contentious than political demands). Instead of formal political institutions (emphasized in the political science literature), which can be illegitimate and not binding, citizen participation better captures the ability of citizens to organize and influence the government. In regimes with high levels of citizen participation, societal feedback provides a check on executive power as the authoritarian leader appeases citizens' interests in order to maintain power through legitimacy.

\section{- Citizens in the developing world want inflows of FDI}

Western media outlets emphasize the harsh conditions and grueling hours of multinational companies operating in the developing world. As a result, it is common for citizens in the developed world to associate FDI with protesting and condemnation by citizens in the developing world. However, the survey evidence and theoretical foundations presented in this dissertation highlight how citizens in authoritarian countries do want greater inflows of FDI as they associate it with increased growth, employment, and opportunity.

\subsection{AVENUES FOR FUTURE RESEARCH}

This dissertation provides several avenues for future research. Each direction for future research would further illuminate and clarify the major points of significance of this study. First, this analysis builds on Chandra and Rudra (2011) to highlight the role of citizen participation in attracting FDI to authoritarian regimes. Citizen participation is measured by Marshall and Gurr's 
(2008) PARCOMP and CIRI's (2008) freedom of assembly. Although strong, both variables largely capture citizen participation in regards to political issues, while the theory focuses on citizen participation on economic issues. Currently, no data measures freedom of association in regards to economic issues and policies. The construction of such a measure would be significant in further understanding and analyzing freedom of association and citizen participation in authoritarian countries. For instance, authoritarian governments that rely on pursuing welfareenhancing policies to maintain legitimacy that have low ranks on citizen participation on political policies might have relatively higher freedoms associated with economic matters (China and Vietnam would be examples) or vice versa. Uncovering this nuanced variation would be very insightful in terms of classifying, understanding, and measuring authoritarianism.

Second, this dissertation analyzes the conditions under which authoritarian leaders comply with international investment treaties, which previous international political economy research has failed to address. The role of citizen participation in procuring stability to the FDI policies established in BITs is the key to understanding the ultimate effectiveness of BITs in attracting FDI inflows. This mechanism could be applied to other types of international treaties signed by authoritarian governments. Citizen participation could provide a clear lens to understanding and analyzing compliance to human rights treaties, which is a major debate in the literature. An application to preferential trade agreements would also be fruitful.

The final avenue for future research is continuing and expanding the survey of managers in multinational companies who invest in authoritarian countries. Primary evidence on business preferences for FDI is integral to developing clear and accurate theories on the determinants of FDI to authoritarian countries. The current survey is limited due to the number of respondents and sample of U.S. companies only. 
Ultimately, this dissertation seeks to inspire future research that further disaggregates and clarifies the domestic and international political factors that both attract and deter FDI inflows to authoritarian countries. Additional empirical measures on authoritarian institutions and survey work on preferences for FDI would contribute greatly to this agenda. Applying the theory and mechanisms discussed here to other fields of international political economy would also further illuminate the validity, breadth, and rigor of the key concepts under analysis. This future research would greatly contribute to the already burgeoning subject of authoritarianism in political science. 


\section{APPENDIX A}

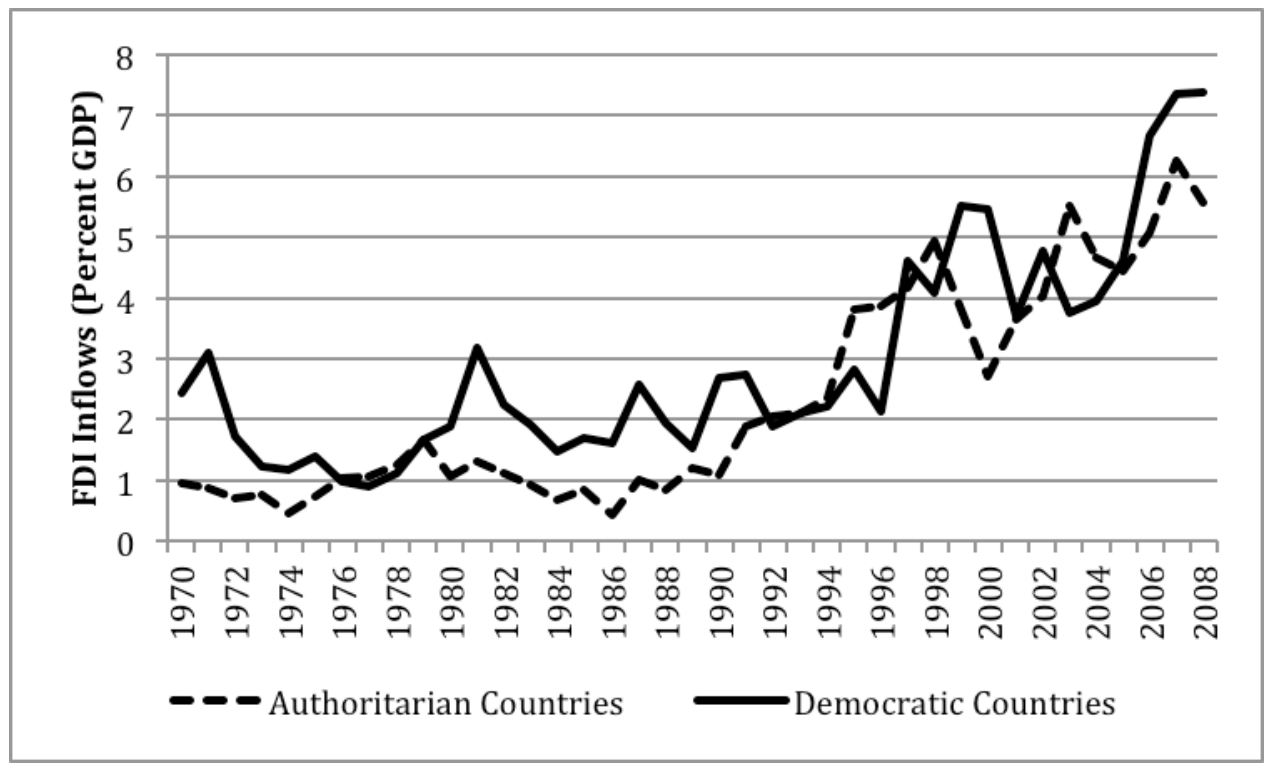

Figure 20 Average FDI Inflows (Percent of GDP) to Democratic and Authoritarian Countries 


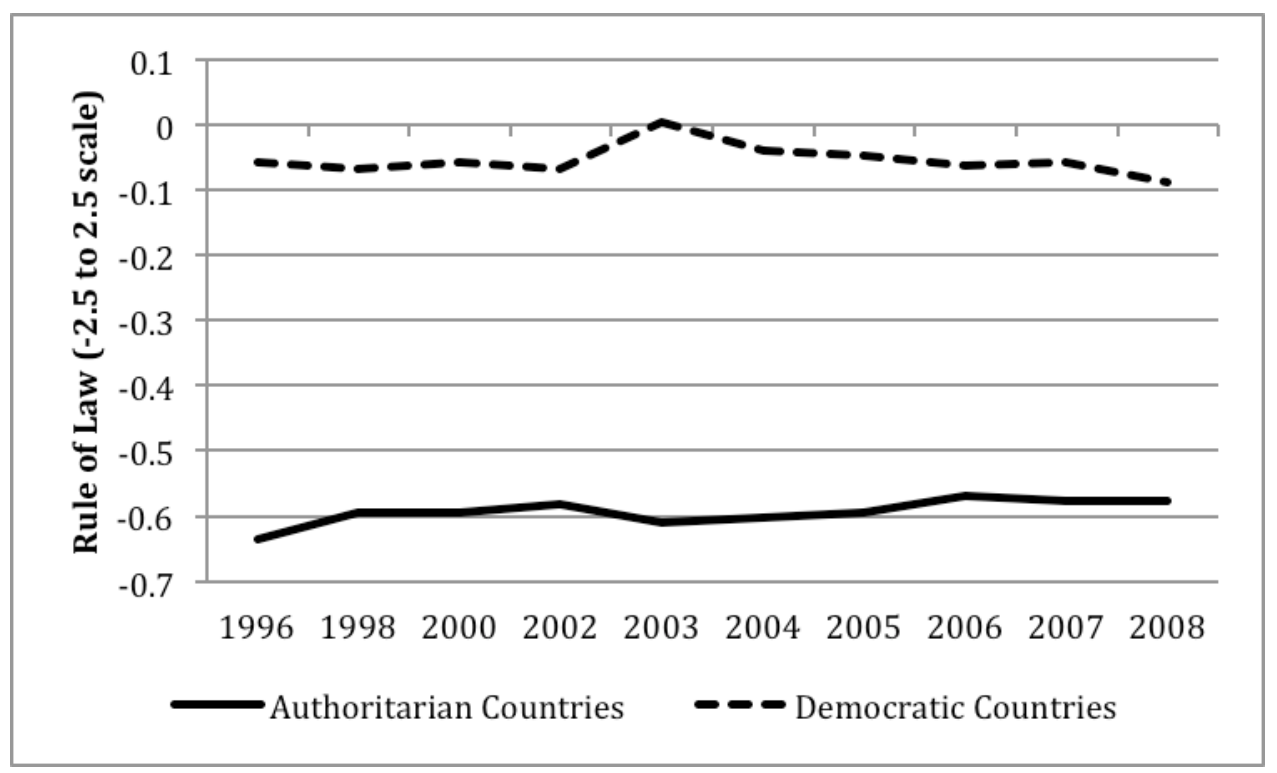

Figure 21 Rule of Law in Democratic and Authoritarian Countries ${ }^{53}$

${ }^{53}$ Rule of Law data is from the World Bank's World Governance Indicators (2010). Rule of law captures perceptions of the extent to which agents have confidence in and abide by the rules of society, and in particular the quality of contract enforcement, property rights, the police, and the courts, as well as the likelihood of crime and violence. 


\section{APPENDIX B}

Table 9 Effect of Inflows of FDI (US Dollars Logged) on Government Confidence

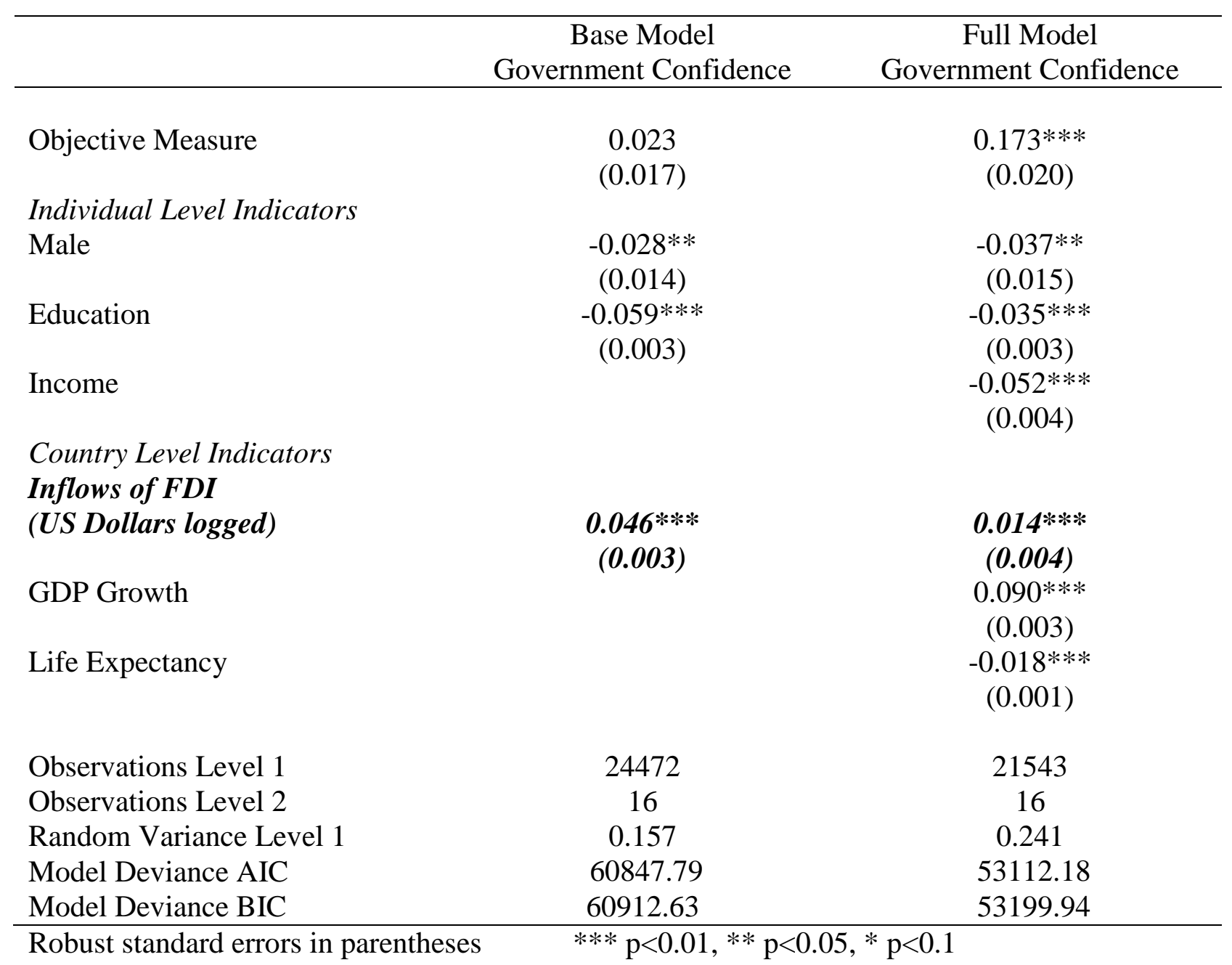


Table 10 Effect of FDI Inflows on Government Confidence: No Objective Measure

\begin{tabular}{|c|c|c|}
\hline & $\begin{array}{c}\text { Base Model } \\
\text { Government Confidence }\end{array}$ & $\begin{array}{c}\text { Full Model } \\
\text { Government Confidence }\end{array}$ \\
\hline \multicolumn{3}{|l|}{ Individual Level Indicators } \\
\hline Male & $\begin{array}{c}-0.027^{*} \\
(0.014)\end{array}$ & $\begin{array}{c}-0.033^{* *} \\
(0.015)\end{array}$ \\
\hline Education & $\begin{array}{c}-0.061^{* * *} \\
(0.003)\end{array}$ & $\begin{array}{c}-0.048 * * * \\
(0.003)\end{array}$ \\
\hline Income & & $\begin{array}{c}-0.041^{* * *} \\
(0.004)\end{array}$ \\
\hline \multicolumn{3}{|l|}{ Country Level Indicators } \\
\hline Inflows of FDI & $\begin{array}{c}0.165^{* * * *} \\
(0.003)\end{array}$ & $\begin{array}{c}0.101 * * * \\
(0.004)\end{array}$ \\
\hline GDP Growth & & $\begin{array}{l}0.043 * * * \\
(0.003)\end{array}$ \\
\hline Life Expectancy & & $\begin{array}{c}-0.030 * * * \\
(0.001)\end{array}$ \\
\hline Observations Level 1 & 24472 & 21543 \\
\hline Observations Level 2 & 16 & 16 \\
\hline Random Variance Level 1 & 0.266 & 0.195 \\
\hline Model Deviance AIC & 60959.75 & 53034.16 \\
\hline Model Deviance BIC & 61016.49 & 53113.93 \\
\hline
\end{tabular}

Table 11 Effect of Inflows of FDI on Government Confidence: Polity Classification

\begin{tabular}{lcc}
\hline & $\begin{array}{c}\text { Base Model } \\
\text { Government Confidence }\end{array}$ & $\begin{array}{c}\text { Full Model } \\
\text { Government Conf }\end{array}$ \\
\hline Objective Measure & $0.275^{* * *}$ & $0.336^{* * *}$ \\
& $(0.015)$ & $(0.019)$ \\
Individual Level Indicators & & \\
Male & $-0.034^{* *}$ & $-0.026^{*}$ \\
& $(0.014)$ & $(0.015)$ \\
Education & $-0.042^{* * *}$ & $-0.041^{* * *}$ \\
& $(0.003)$ & $(0.003)$ \\
Income & & $-0.011^{* * *}$ \\
Country Level Indicators & & $(0.004)$ \\
Inflows of FDI & & $\mathbf{0 . 0 8 6 ^ { * * * }}$ \\
GDP Growth & $\mathbf{0 . 1 4 1 * * *}$ & $(\mathbf{0 . 0 0 4 )}$ \\
& $\mathbf{( 0 . 0 0 3 )}$ & $0.030^{* * *}$
\end{tabular}


Life Expectancy

$(0.003)$

$-0.004 * * *$

(0.001)

Observations Level 1

Observations Level 2

23286

16

20766

Random Variance Level 1

0.254

16

Model Deviance AIC

58091.75

0.140

Model Deviance BIC

58156.19

51445.15

51532.5

Robust standard errors in parentheses

${ }^{* * *} \mathrm{p}<0.01,{ }^{* *} \mathrm{p}<0.05,{ }^{*} \mathrm{p}<0.1$ 


\section{APPENDIX C}

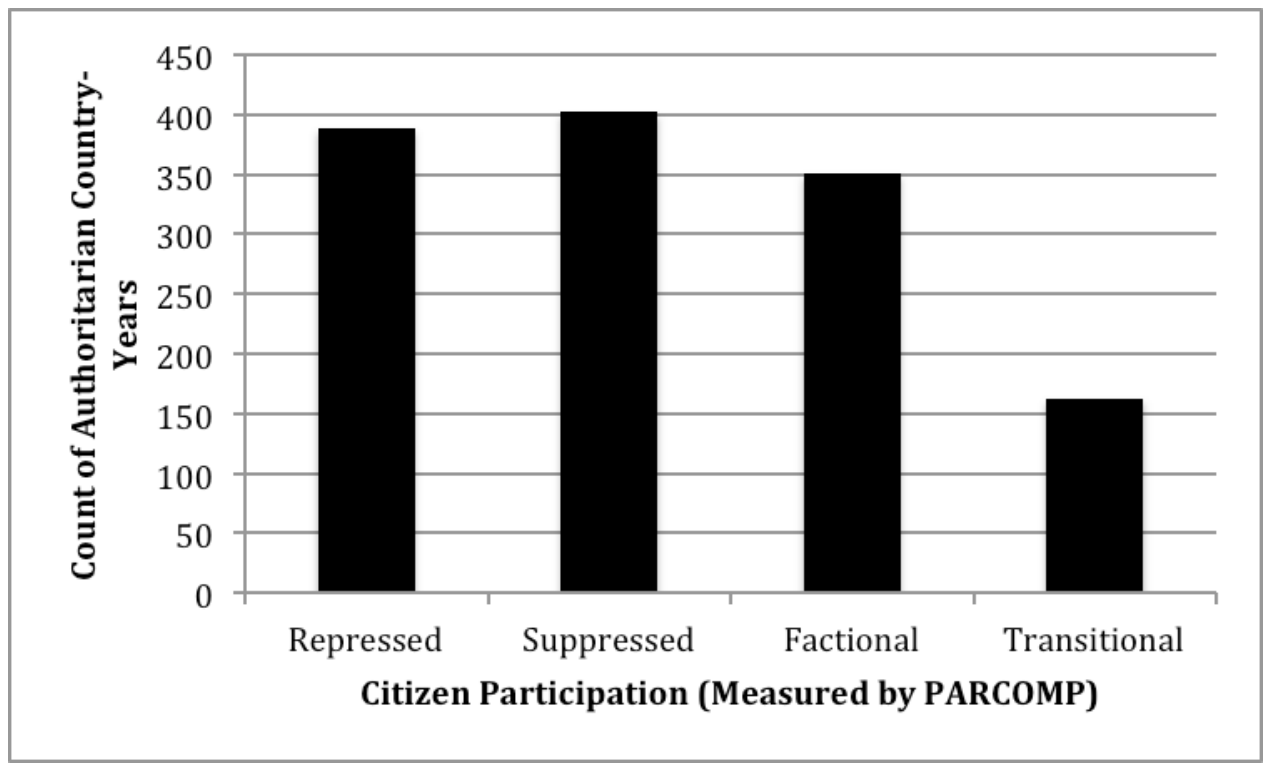

Figure 22 Citizen Participation in Authoritarian Countries between 1990 and 2008 


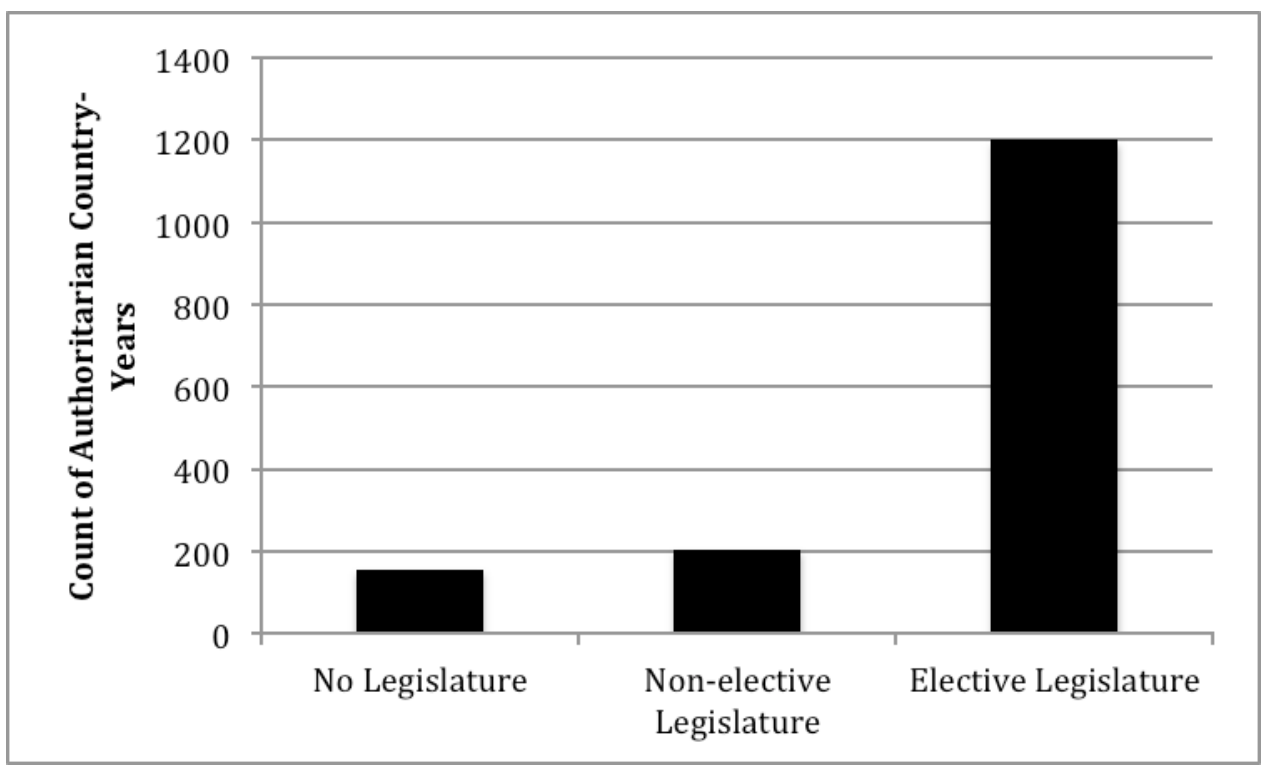

Figure 23 Legislatures in Authoritarian Countries between 1990 and 2008

Table 12 Authoritarian Institutions Comparison in 2008

\begin{tabular}{|c|c|c|c|c|}
\hline Country & Regime & Legislature & Parcomp & $\begin{array}{c}\text { FDI inflows } \\
\text { (logged) }\end{array}$ \\
\hline Tanzania & & Elected & 2 & 19.81 \\
\hline Mozambique & & Elected & 4 & 20.20 \\
\hline $\begin{array}{c}\text { Democratic } \\
\text { Republic Congo }\end{array}$ & & Elected & 4 & 21.27 \\
\hline North Korea & Civilian & & 1 & 17.60 \\
\hline Cambodia & Civilian & & 4 & 20.52 \\
\hline Syria & Military & & 1 & 21.11 \\
\hline Egypt & Military & & 3 & 22.97 \\
\hline Morocco & Royal & & 4 & 21.63 \\
\hline Jordan & Royal & & 21.76 \\
\hline
\end{tabular}




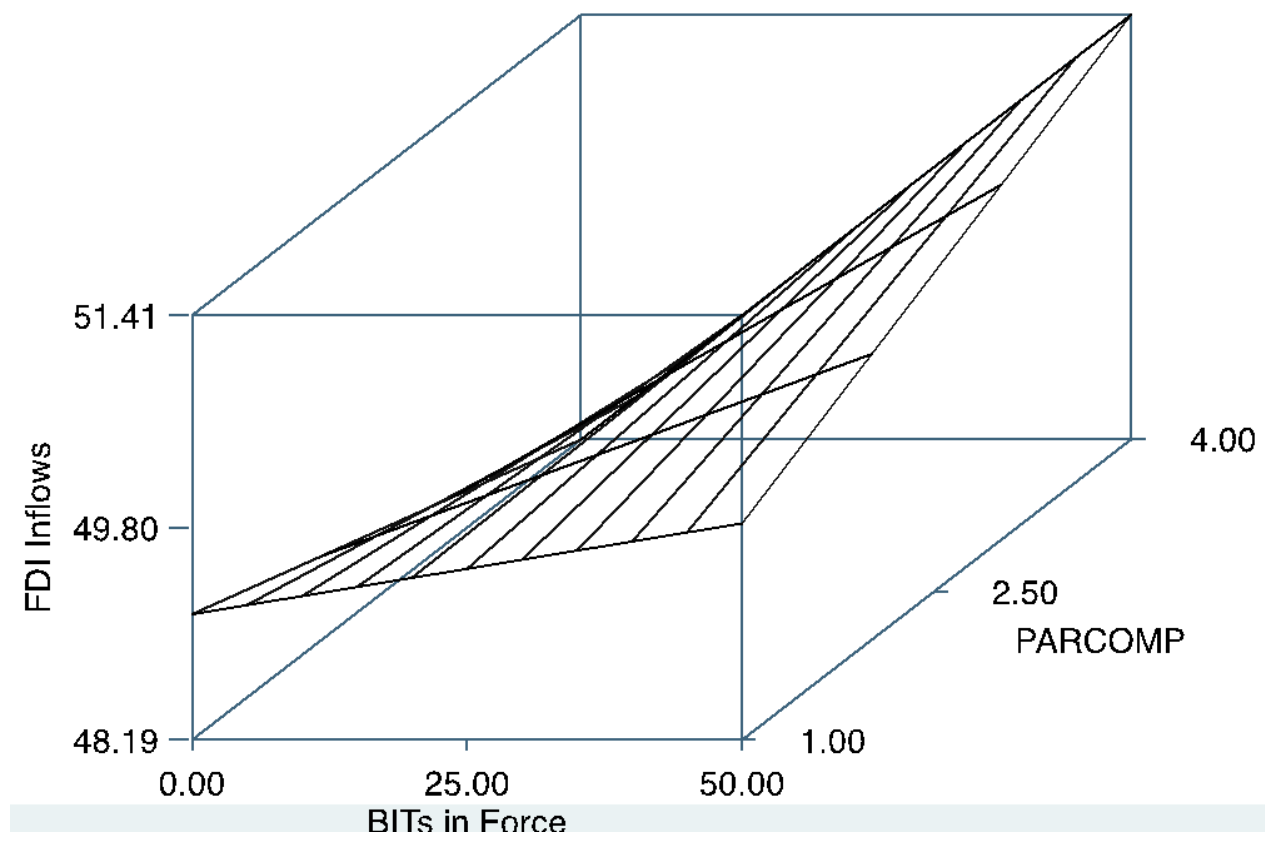

Figure 24 Determinants of FDI Inflows: 3D Graph

Table 13 Determinants of Rule of Law and Political Risk in Authoritarian Countries

\begin{tabular}{lcc}
\hline & Rule of Law & Political Risk \\
\hline BITs & $-0.00627^{* *}$ & $-0.188^{* * *}$ \\
PARCOMP & $(0.00283)$ & $(0.0468)$ \\
BITs*PARCOMP & 0.0202 & -0.116 \\
& $(0.0257)$ & $(0.346)$ \\
GDP Growth & $\mathbf{0 . 0 0 1 9 0 *}$ & $\mathbf{0 . 0 5 4 7 * * *}$ \\
Life Expectancy & $\mathbf{( 0 . 0 0 1 0 1 )}$ & $\mathbf{( 0 . 0 1 9 0 )}$ \\
& 0.000205 & $(0.0306)$ \\
GDP per capita (logged) & $(0.00114)$ & $0.641^{* * *}$ \\
& $0.0344 * * *$ & $(0.0698)$ \\
\end{tabular}


Country Fixed Effects

Yes

Yes

Yearly Dummies

Yes

Yes

Observations

630

1,217

R-squared

0.147

0.506

Number of Countries

Standard errors in parentheses

${ }^{* * *} \mathrm{p}<0.01,{ }^{* *} \mathrm{p}<0.05,{ }^{*} \mathrm{p}<0.1$

Table 14 Determinants of FDI Inflows (\% GDP) in Authoritarian Countries

\begin{tabular}{lccc}
\hline & $(1)$ & $(2)$ & $(3)$ \\
\hline & & & -0.00766 \\
BITs in force & -0.0375 & -0.0566 & $(0.0707)$ \\
PARCOMP & $(0.0479)$ & $(0.0456)$ & -0.375 \\
& -0.110 & -0.333 & $(1.024)$ \\
BITs*PARCOMP & $(0.858)$ & $(0.850)$ & $\mathbf{0 . 0 6 3 4 ^ { * * }}$ \\
& $\mathbf{0 . 0 4 5 9 ^ { * * * }}$ & $\mathbf{0 . 0 5 1 0 ^ { * * * }}$ & $\mathbf{( 0 . 0 2 4 8 )}$ \\
Rule of Law & $\mathbf{( 0 . 0 1 4 2 )}$ & $\mathbf{( 0 . 0 1 3 8 )}$ & 0.579 \\
& 1.891 & 2.043 & $(1.416)$ \\
Log Population & $(1.279)$ & $(1.331)$ & $12.38^{* *}$ \\
& 3.567 & 3.662 & $(6.149)$ \\
GDP Growth & $(3.057)$ & $(3.819)$ & -0.0326 \\
& & -0.0925 & $(0.0734)$ \\
Life Expectancy & & $(0.0570)$ & $0.379 * *$ \\
& & 0.147 & $(0.153)$ \\
Oil Rent (\% GDP) & & $(0.119)$ & $-0.231^{* *}$ \\
& & & $(0.107)$ \\
Inflation & & & 0.000549 \\
& & & $(0.0109)$ \\
Log GDP per capita & & & $-4.104^{* * *}$ \\
& & & -21.145 \\
Democracy Dummy & & & $(16.87)$ \\
& & & \\
Country Fixed Effects & & Yes & Yes \\
Decade Dummies & Yes & & 626 \\
Observations & Yes & & 0.646 \\
R-squared & 632 & &
\end{tabular}




\begin{tabular}{|c|c|c|}
\hline Number of Countries & 81 & 81 \\
\hline
\end{tabular}

Table 15 Determinants of FDI Inflows to Non Resource Rich Authoritarian Countries

\begin{tabular}{|c|c|c|c|}
\hline & $(1)$ & $(2)$ & (3) \\
\hline \multirow[t]{2}{*}{ BITs in force } & 0.0245 & -0.00604 & 0.0114 \\
\hline & $(0.0204)$ & $(0.0249)$ & $(0.0227)$ \\
\hline \multirow[t]{2}{*}{ PARCOMP } & 0.0705 & -0.118 & -0.199 \\
\hline & $(0.114)$ & $(0.177)$ & $(0.172)$ \\
\hline \multirow[t]{2}{*}{ BITs*PARCOMP } & $0.0228 * * *$ & $0.0235 * * *$ & 0.00903 \\
\hline & $(0.00496)$ & $(0.00800)$ & $(0.00682)$ \\
\hline \multirow[t]{2}{*}{ Rule of Law } & $1.263 * * *$ & 0.0750 & 0.0950 \\
\hline & $(0.115)$ & $(0.260)$ & $(0.272)$ \\
\hline \multirow[t]{2}{*}{ Log Population } & $0.495 * * *$ & $6.424 * * *$ & $5.371^{* * *}$ \\
\hline & $(0.0910)$ & $(1.412)$ & $(1.292)$ \\
\hline \multirow[t]{2}{*}{ GDP Growth } & & $0.0205^{*}$ & 0.00655 \\
\hline & & $(0.0123)$ & $(0.0155)$ \\
\hline \multirow[t]{2}{*}{ Life Expectancy } & & 0.0559 & 0.00354 \\
\hline & & $(0.0458)$ & $(0.0459)$ \\
\hline \multirow[t]{2}{*}{ Oil Rent (\% GDP) } & & & 0.0809 \\
\hline & & & $(0.105)$ \\
\hline \multirow[t]{2}{*}{ Inflation } & & & 2.77e-05 \\
\hline & & & $(4.94 \mathrm{e}-05)$ \\
\hline \multirow[t]{2}{*}{ Log GDP per capita } & & & $0.993 * * *$ \\
\hline & & & $(0.207)$ \\
\hline \multirow[t]{2}{*}{ Democracy Dummy } & & & $9.466 * * *$ \\
\hline & & & (3.383) \\
\hline Country Fixed Effects & No & Yes & Yes \\
\hline Decade Dummies & Yes & Yes & Yes \\
\hline Observations & 365 & 357 & 313 \\
\hline R-squared & 0.984 & 0.994 & 0.993 \\
\hline Number of Countries & 54 & 53 & 49 \\
\hline
\end{tabular}




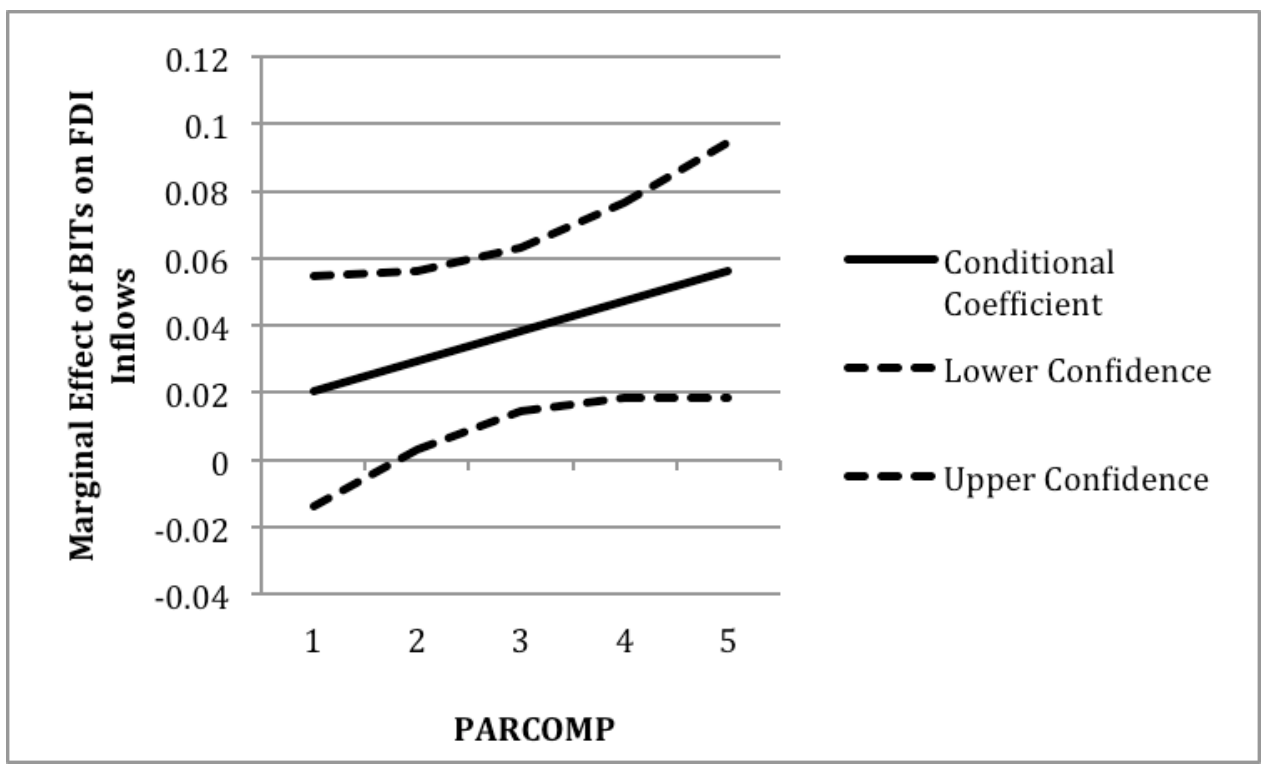

Figure 25 Marginal Effects of BITs on FDI Inflows to Non Resource Rich Authoritarian Countries (Full Model)

Table 16 Inflows of FDI to Resource Rich Authoritarian Countries (All Oil Producers) $\quad$ (Top 50\% of Oil Producers)

$\begin{array}{lcc}\text { BITs in force } & -0.00152 & -0.0154 \\ & (0.0270) & (0.0454) \\ \text { PARCOMP } & -0.450 * & 0.373 \\ & (0.261) & (0.450) \\ \text { BITs*PARCOMP } & \mathbf{0 . 0 2 0 2 * *} & \mathbf{0 . 0 2 6 2} \\ & \mathbf{( 0 . 0 0 8 7 5 )} & \mathbf{( 0 . 0 1 6 6 )} \\ \text { Rule of Law } & 0.433 & -0.492 \\ & (0.440) & (0.700) \\ \text { Log Population } & 1.412 & 0.972 \\ & (1.022) & (0.632) \\ \text { GDP Growth } & 0.0114 & 0.0298 \\ & (0.00901) & (0.0199) \\ \text { Life Expectancy } & 0.100 & -0.0523 \\ & (0.135) & (0.220) \\ \text { Oil Rent (\% GDP) } & -0.00450 & 0.0356 * * \\ & (0.0147) & (0.0148) \\ \text { Inflation } & 0.00182 & 0.0300 \\ & (0.00267) & (0.0230) \\ \text { Log GDP per capita } & 0.525 * * * & 0.830 * * * \\ & (0.148) & (0.304) \\ \text { Democracy Dummy } & 5.612 & 4.229 \\ & (4.315) & (2.917)\end{array}$




\begin{tabular}{lcc} 
Observations & 198 & 109 \\
R-squared & 0.993 & 0.987 \\
Number of Countries & 34 & 17 \\
\hline Robust standard errors in parentheses & $* * * \mathrm{p}<0.01,{ }^{* *} \mathrm{p}<0.05,{ }^{*} \mathrm{p}<0.1$
\end{tabular}

Table 17 Determinants of FDI Inflows by Sector

\begin{tabular}{|c|c|c|c|}
\hline & (Primary Sector FDI) & (Secondary Sector FDI) & (Tertiary Sector FDI) \\
\hline \multirow[t]{2}{*}{ BITs in force } & -1.293 & $-0.475 *$ & $-2.060 * *$ \\
\hline & $(0.919)$ & $(0.253)$ & $(0.918)$ \\
\hline \multirow[t]{2}{*}{ PARCOMP } & -1.441 & 1.260 & -2.296 \\
\hline & (3.682) & $(0.948)$ & (2.125) \\
\hline \multirow[t]{2}{*}{ BITs*PARCOMP } & 0.460 & $0.195 *$ & $0.725 *$ \\
\hline & $(0.368)$ & $(0.0987)$ & $(0.362)$ \\
\hline \multirow[t]{2}{*}{ Rule of Law } & 6.502 & -1.340 & $-26.47 * * *$ \\
\hline & (4.696) & $(1.236)$ & $(5.902)$ \\
\hline \multirow[t]{2}{*}{ Log Population } & -28.34 & 6.677 & 18.90 \\
\hline & (29.56) & (7.604) & (24.83) \\
\hline Country Fixed Effects & Yes & Yes & Yes \\
\hline Observations & 37 & 37 & 46 \\
\hline R-squared & 0.280 & 0.552 & 0.536 \\
\hline Number of Countries & 18 & 20 & 18 \\
\hline
\end{tabular}

Table 18 Determinants of FDI Inflows: Polity Classification

(Base)

BITs in force

PARCOMP

BITs*PARCOMP

Rule of Law

Log Population

GDP Growth
0.00993

(0.0281)

$-0.257^{*}$

(0.143)

$0.0226 * *$

(0.0107)

$0.688 * * *$

(0.104)

$0.619 * * *$

(0.107)
(Full)
0.0140
(0.0202)
$-0.342 * * *$
(0.108)
0.0125 *
(0.00652)
0.0256
(0.158)
2.305***
(0.758)
$-0.000890$ 


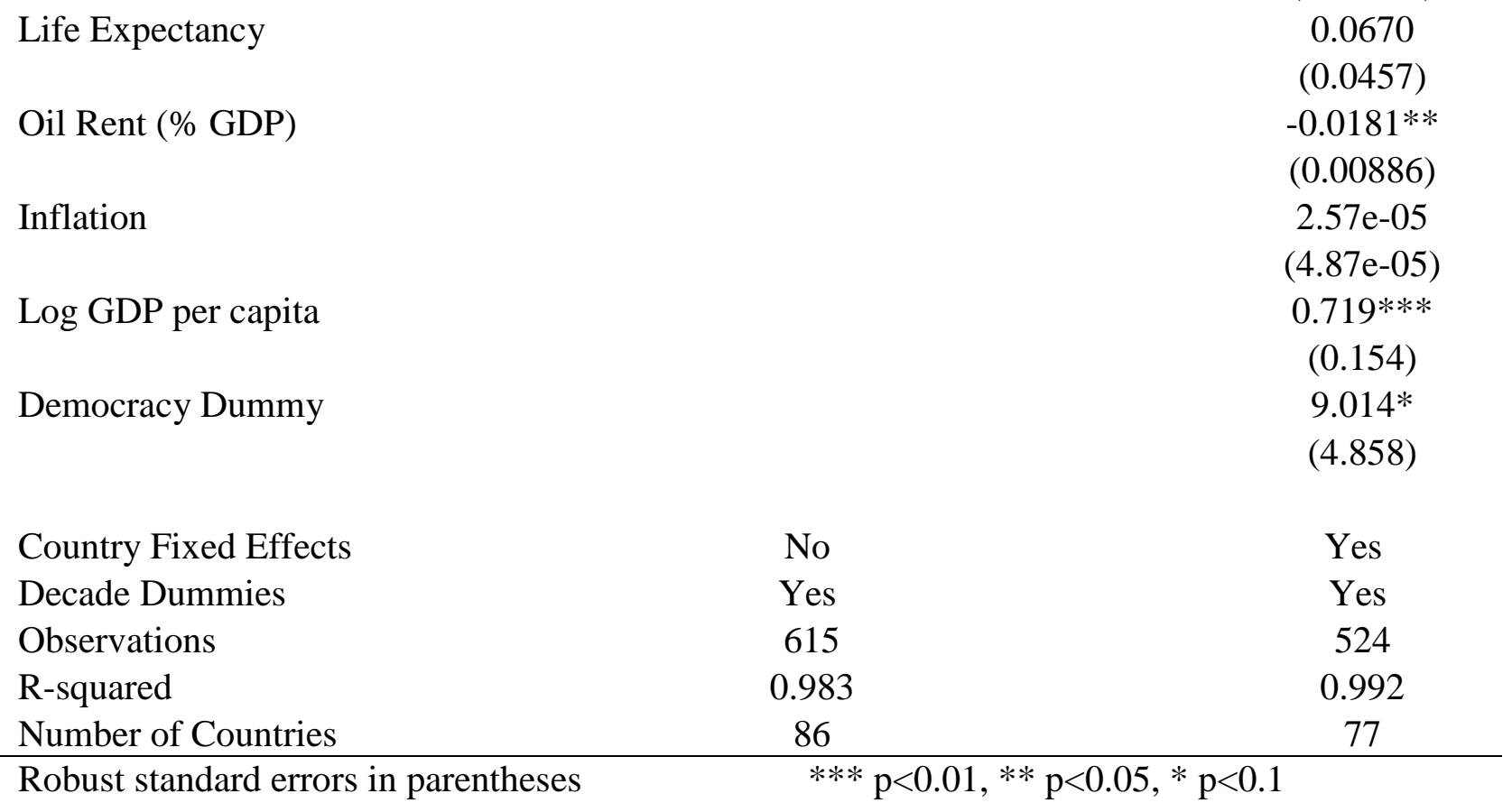

Table 19 Determinants of FDI Inflows: All Developing Countries

\begin{tabular}{ll}
\hline & \\
BITs in force & 0.0116 \\
& $(0.0128)$ \\
PARCOMP & $-0.192^{* *}$ \\
BITs*PARCOMP & $(0.0866)$ \\
& $\mathbf{0 . 0 0 4 9 5 *}$ \\
Rule of Law & $\mathbf{( 0 . 0 0 2 9 9 )}$ \\
& $0.264^{* *}$ \\
Log Population & $(0.131)$ \\
& $2.329^{* * *}$ \\
GDP Growth & $(0.574)$ \\
& 0.000698 \\
Life Expectancy & $(0.00719)$ \\
Oil Rent (\% GDP) & $0.0615^{* *}$ \\
Inflation & $(0.0258)$ \\
Log GDP per capita & $-0.0285^{* * *}$ \\
& $(0.00931)$ \\
& $3.35 \mathrm{e}-05$ \\
& $(4.75 \mathrm{e}-05)$ \\
& $1.072^{* * *}$ \\
& $(0.111)$
\end{tabular}




$\begin{array}{lc}\text { Democracy Dummy } & 8.802^{* *} \\ & (3.596) \\ & \text { Yes } \\ \text { Country Fixed Effects } & \text { Yes } \\ \text { Decade Dummies } & 1074 \\ \text { Observations } & 0.992 \\ \text { R-squared } & 122 \\ \text { Number of Countries } & * * * \mathrm{p}<0.01, * * \mathrm{p}<0.05, * \mathrm{p}<0.1\end{array}$

Table 20 Determinants of FDI Inflows: Fixed Effects Regression

\begin{tabular}{|c|c|c|c|}
\hline & $(1)$ & $(2)$ & (3) \\
\hline BITs in force & $\begin{array}{l}0.0289 * \\
(0.0163)\end{array}$ & $\begin{array}{l}0.0168 \\
(0.0211)\end{array}$ & $\begin{array}{l}-0.00705 \\
(0.0243)\end{array}$ \\
\hline PARCOMP & $\begin{array}{l}-0.00512 \\
(0.159)\end{array}$ & $\begin{array}{l}-0.0961 \\
(0.189)\end{array}$ & $\begin{array}{l}-0.131 \\
(0.180)\end{array}$ \\
\hline BITs*PARCOMP & $\begin{array}{l}0.0105^{*} \\
(0.00628)\end{array}$ & $\begin{array}{l}0.0125^{* *} \\
(0.00630)\end{array}$ & $\begin{array}{l}0.0112^{*} \\
(0.00664)\end{array}$ \\
\hline Rule of Law & $\begin{array}{l}0.530 * * \\
(0.262)\end{array}$ & $\begin{array}{l}0.344 \\
(0.434)\end{array}$ & $\begin{array}{l}0.433 \\
(0.458)\end{array}$ \\
\hline Log Population & $\begin{array}{l}4.312^{* * *} \\
(0.549)\end{array}$ & $\begin{array}{l}4.002 * * * \\
(0.938)\end{array}$ & $\begin{array}{l}0.797 \\
(1.018)\end{array}$ \\
\hline GDP Growth & & $\begin{array}{l}0.0185^{*} \\
(0.00992)\end{array}$ & $\begin{array}{l}0.00421 \\
(0.0182)\end{array}$ \\
\hline Life Expectancy & & $\begin{array}{l}0.0738 \\
(0.0510)\end{array}$ & $\begin{array}{l}0.0218 \\
(0.0608)\end{array}$ \\
\hline Oil Rent (\% GDP) & & & $\begin{array}{c}-0.00313 \\
(0.0144)\end{array}$ \\
\hline Inflation & & & $\begin{array}{l}-2.00 \mathrm{e}-05 \\
(2.21 \mathrm{e}-05)\end{array}$ \\
\hline Log GDP per capita & & & $\begin{array}{l}0.115 \\
(0.518)\end{array}$ \\
\hline Workers' Rights & & & $\begin{array}{l}0.241 \\
(0.161)\end{array}$ \\
\hline Corruption & & & $\begin{array}{l}0.0985 \\
(0.216)\end{array}$ \\
\hline Year Effects & No & No & Yes \\
\hline
\end{tabular}




\begin{tabular}{llll} 
Observations & 604 & 593 & 499 \\
R-squared (within) & 0.293 & 0.303 & 0.373 \\
Number of Countries & 82 & 81 & 74 \\
\hline Robust standard errors in parentheses & $* * * \mathrm{p}<0.01,{ }^{* *} \mathrm{p}<0.05,{ }^{*} \mathrm{p}<0.1$
\end{tabular}

Table 21 Determinants of FDI: Imputed Data

\begin{tabular}{|c|c|c|c|c|}
\hline BITs in force & $\begin{array}{c}0.0493 * * * \\
(0.0102)\end{array}$ & $\begin{array}{c}0.0505 * * * \\
(0.0102)\end{array}$ & $\begin{array}{c}0.0467 * * * \\
(0.00552)\end{array}$ & $\begin{array}{c}0.0479 * * * \\
(0.00548)\end{array}$ \\
\hline PARCOMP & $\begin{array}{c}0.184^{* * *} \\
(0.0606)\end{array}$ & $\begin{array}{c}0.166^{* * * *} \\
(0.0597)\end{array}$ & & \\
\hline BITs*PARCOMP & $\begin{array}{l}0.000159 \\
(0.00526)\end{array}$ & $\begin{array}{l}0.000124 \\
(0.00526)\end{array}$ & & \\
\hline Free Assembly & & & $\begin{array}{l}0.153 * * \\
(0.0782)\end{array}$ & $\begin{array}{c}0.135^{*} \\
(0.0806)\end{array}$ \\
\hline BITs*Free Assemble & & & $\begin{array}{c}0.0176^{*} \\
(0.00901)\end{array}$ & $\begin{array}{c}0.0173^{*} \\
(0.00897)\end{array}$ \\
\hline Rule of Law & $\begin{array}{l}0.0385 \\
(0.201)\end{array}$ & $\begin{array}{l}0.0999 \\
(0.208)\end{array}$ & $\begin{array}{l}0.0583 \\
(0.204)\end{array}$ & $\begin{array}{c}0.121 \\
(0.212)\end{array}$ \\
\hline Log Population & $\begin{array}{l}1.388 * * * \\
(0.0937)\end{array}$ & $\begin{array}{l}1.415^{* * *} \\
(0.0993)\end{array}$ & $\begin{array}{l}1.451 * * * \\
(0.0888)\end{array}$ & $\begin{array}{l}1.449 * * * \\
(0.0955)\end{array}$ \\
\hline GDP Growth & $\begin{array}{c}0.0341 * * * \\
(0.00651)\end{array}$ & $\begin{array}{c}0.0299 * * * \\
(0.00675)\end{array}$ & $\begin{array}{c}0.0344 * * * \\
(0.00649)\end{array}$ & $\begin{array}{c}0.0302 * * * \\
(0.00676)\end{array}$ \\
\hline Oil Rent (\% GDP) & & $\begin{array}{c}0.0153 * * * \\
(0.00518)\end{array}$ & & $\begin{array}{c}0.0155^{* * * *} \\
(0.00524)\end{array}$ \\
\hline Inflation & & $\begin{array}{c}5.20 \mathrm{e}-06 \\
(9.55 \mathrm{e}-05)\end{array}$ & & $\begin{array}{c}1.56 \mathrm{e}-05 \\
(9.60 \mathrm{e}-05)\end{array}$ \\
\hline Log GDP per capita & $\begin{array}{c}0.665^{* * *} \\
(0.0741)\end{array}$ & $\begin{array}{c}0.585 * * * \\
(0.0873)\end{array}$ & $\begin{array}{c}0.662 * * * \\
(0.0746)\end{array}$ & $\begin{array}{c}0.582 * * * \\
(0.0883)\end{array}$ \\
\hline Corruption & $\begin{array}{c}0.444 * * * \\
(0.0986)\end{array}$ & $\begin{array}{c}0.459 * * * \\
(0.0988)\end{array}$ & $\begin{array}{c}0.450 * * * \\
(0.0978)\end{array}$ & $\begin{array}{c}0.467 * * * \\
(0.0983)\end{array}$ \\
\hline Observations & 2,166 & 2,166 & 2,166 & 2,166 \\
\hline Number of Countries & 57 & 57 & 57 & 57 \\
\hline
\end{tabular}

Table 22 Determinants of FDI Inflows: Arellano Bond Estimation

\begin{tabular}{ccc} 
Log of Inflows of & Log of Inflows of & Log of Inflows of \\
FDI & FDI & FDI \\
\hline
\end{tabular}




\begin{tabular}{lccc} 
Inflows of FDI (Lagged) & $0.416^{* * *}$ & $0.351^{* * *}$ & $0.310^{* * *}$ \\
BITs in force & $(0.0347)$ & $(0.0339)$ & $(0.0508)$ \\
& 0.0138 & 0.0124 & -0.0432 \\
PARCOMP & $(0.0205)$ & $(0.0177)$ & $(0.0385)$ \\
& 0.108 & -0.0243 & -0.0602 \\
BITs*PARCOMP & $(0.260)$ & $(0.209)$ & $(0.285)$ \\
& $\mathbf{0 . 0 1 4 4 * *}$ & $\mathbf{0 . 0 0 8 7 1 *}$ & $\mathbf{0 . 0 1 5 0}$ \\
Rule of Law & $\mathbf{( 0 . 0 0 6 6 7 )}$ & $\mathbf{( 0 . 0 0 4 5 2 )}$ & $\mathbf{( 0 . 0 0 9 5 3 )}$ \\
& $0.634^{* * *}$ & $0.286^{* *}$ & 0.289 \\
Log Population & $(0.191)$ & $(0.117)$ & $(0.330)$ \\
& $2.234^{* * *}$ & 0.744 & -0.464 \\
GDP Growth & $(0.430)$ & $(0.792)$ & $(1.181)$ \\
& & $0.0129 * * *$ & $0.00984^{*}$ \\
Life Expectancy & & $(0.00491)$ & $(0.00545)$ \\
& & $0.282^{* * *}$ & $0.181^{*}$ \\
Oil Rent (\% GDP) & & $(0.0544)$ & $(0.104)$ \\
& & & $-0.0269 * *$ \\
Inflation & & & $(0.0120)$ \\
& & & $(6.40 \mathrm{e}-06)$ \\
Log GDP per capita & & & $0.939^{* * *}$ \\
& & & $(0.184)$ \\
Observations & & 315 & 279 \\
Number of countries & & 68 & 61 \\
\hline Robust standard errors in parentheses & & &
\end{tabular}

Table 23 Determinants of FDI Inflows: Instrumental Variable Regression

\section{Log of Inflows of FDI}

$\begin{array}{lc}\text { BITs in force }^{\mathrm{X}} & -0.140^{*} \\ & (0.0773) \\ \text { PARCOMP }^{\mathrm{XX}} & -0.293 \\ & (0.304) \\ \text { BITs*PARCOMP }^{X \boldsymbol{X X}} & \mathbf{0 . 0 5 2 1 * *} \\ & (\mathbf{0 . 0 2 5 1 )} \\ \text { Rule of Law } & 1.585^{* * *} \\ & (0.245) \\ \text { Log Population } & 0.989^{* * *} \\ & (0.226) \\ \text { GDP Growth } & 0.105^{* * *} \\ & (0.0273) \\ \text { Democracy Dummy } & -0.393 \\ & (0.447)\end{array}$

Observations 572 
R-squared

Kleibergen-Paap pvalue

Kleibergen-Paap F Statistic

Hansen J Statistic pvalue

Endogeneity Test pvalue

Robust standard errors in parentheses

*** $\mathrm{p}<0.01, * * \mathrm{p}<0.05, * \mathrm{p}<0.1$

$\mathrm{X}$ instrumented by UNESCO conventions in force

$\mathrm{XX}$ instrumented by public health expenditure as a percent of GDP and women's political rights XXX instrumented by the interaction of UNESCO conventions in force and public health expenditures as a percent of GDP

Table 24 Determinants of FDI Inflows: Selection Model

$\begin{array}{lc}\text { BITs in force } & 0.00629 \\ \text { PARCOMP } & (0.0190) \\ \text { BITs*PARCOMP } & 0.0293 \\ \text { Rule of Law } & (0.196) \\ & \mathbf{0 . 0 1 3 7 ^ { * * }} \\ \text { Log Population } & \mathbf{0 . 0 0 6 2 9 )} \\ & 0.507 \\ \text { GDP Growth } & (0.341) \\ & 2.165^{* * *} \\ \text { Life Expectancy } & (0.803) \\ \text { Oil Rent (\% GDP) } & -0.0186 \\ & (0.0141) \\ \text { Inflation } & 0.0804 * \\ & (0.0421) \\ \text { Log GDP per capita } & 0.00224 \\ \text { Democracy Dummy } & (0.0120) \\ \text { BIT Signing Dummy } & 3.88 \mathrm{e}-05 \\ & (3.96 \mathrm{e}-05) \\ & 0.828^{* * *} \\ & (0.194) \\ & 5.313^{* * *} \\ & (1.327) \\ & 0.0895 \\ & (0.738)\end{array}$

Selection Equation Results: Dependent Variable BIT Signing Dummy 
$\begin{array}{lc}\text { UNESCO Conventions in Force } & 0.0338^{* *} \\ \text { PTAs } & (0.0137) \\ & -0.0586 \\ \text { Government Stability } & (0.0428) \\ & 0.157^{* * *} \\ \text { GDP Growth } & (0.0486) \\ & 0.0339^{* *} \\ \text { Log GDP per capita } & (0.0145) \\ & 0.138^{* * *} \\ & (0.0528)\end{array}$

Observations

399

Robust standard errors in parentheses

*** $\mathrm{p}<0.01,{ }^{* *} \mathrm{p}<0.05,{ }^{*} \mathrm{p}<0.1$

Table 25 Determinants of FDI Inflows: Additional Controls

\begin{tabular}{|c|c|c|c|c|c|}
\hline & (1) & (2) & (3) & (4) & (5) \\
\hline BITs in force & $\begin{array}{l}-0.0136 \\
(0.0185)\end{array}$ & $\begin{array}{l}0.00833 \\
(0.0178)\end{array}$ & $\begin{array}{l}0.00669 \\
(0.0237)\end{array}$ & $\begin{array}{l}-0.00115 \\
(0.0198)\end{array}$ & $\begin{array}{l}-0.0112 \\
(0.0190)\end{array}$ \\
\hline PARCOMP & $\begin{array}{l}-0.298 * \\
(0.180)\end{array}$ & $\begin{array}{l}-0.280 \\
(0.185)\end{array}$ & $\begin{array}{l}-0.337 * \\
(0.179)\end{array}$ & $\begin{array}{l}-0.138 \\
(0.171)\end{array}$ & $\begin{array}{l}-0.292 \\
(0.182)\end{array}$ \\
\hline BITs* & & & & & \\
\hline PARCOMP & $\begin{array}{r}0.0139 * * * \\
(0.00495)\end{array}$ & $\begin{array}{l}0.0120 * * \\
(0.00510)\end{array}$ & $\begin{array}{l}0.0141 * * \\
(0.00705)\end{array}$ & $\begin{array}{c}0.0159 * * * \\
(0.00526)\end{array}$ & $\begin{array}{c}0.0174 * * * \\
(0.00551)\end{array}$ \\
\hline Rule of Law & $\begin{array}{c}-0.0137 \\
(0.00900)\end{array}$ & $\begin{array}{l}-0.0180 * * \\
(0.00888)\end{array}$ & $\begin{array}{l}-0.192 \\
(0.257)\end{array}$ & $\begin{array}{c}0.306 \\
(0.265)\end{array}$ & $\begin{array}{l}-0.0210^{* *} \\
(0.00903)\end{array}$ \\
\hline Log Population & $\begin{array}{l}-0.0100 \\
(0.251)\end{array}$ & $\begin{array}{l}-0.138 \\
(0.229)\end{array}$ & $\begin{array}{c}3.502 * * * \\
(1.094)\end{array}$ & $\begin{array}{c}1.477 * * * \\
(0.500)\end{array}$ & $\begin{array}{c}0.195 \\
(0.299)\end{array}$ \\
\hline GDP Growth & $\begin{array}{c}0.726 \\
(0.743)\end{array}$ & $\begin{array}{c}2.631^{* * * *} \\
(0.776)\end{array}$ & $\begin{array}{l}0.00415 \\
(0.0103)\end{array}$ & $\begin{array}{l}-0.00381 \\
(0.00960)\end{array}$ & $\begin{array}{c}2.221^{* * * *} \\
(0.791)\end{array}$ \\
\hline Life Expectancy & $\begin{array}{c}-7.45 \mathrm{e}-06 \\
(5.06 \mathrm{e}- \\
05)\end{array}$ & $\begin{array}{l}2.73 e-05 \\
(4.76 e-05)\end{array}$ & $\begin{array}{l}0.0809 * * \\
(0.0378)\end{array}$ & $\begin{array}{l}0.100 * * \\
(0.0390)\end{array}$ & $\begin{array}{l}2.78 \mathrm{e}-05 \\
(4.82 \mathrm{e}-05)\end{array}$ \\
\hline Oil Rent (\% GDP) & $\begin{array}{c}0.0107 \\
(0.00921)\end{array}$ & $\begin{array}{c}0.00675 \\
(0.00869)\end{array}$ & $\begin{array}{c}-0.0242 * * * \\
(0.00897)\end{array}$ & $\begin{array}{l}-0.0103 \\
(0.0113)\end{array}$ & $\begin{array}{l}0.00466 \\
(0.0102)\end{array}$ \\
\hline Inflation & $\begin{array}{l}0.0649 * \\
(0.0345)\end{array}$ & $\begin{array}{l}0.0773 * * \\
(0.0319)\end{array}$ & $\begin{array}{c}1.53 \mathrm{e}-05 \\
(4.90 \mathrm{e}-05)\end{array}$ & $\begin{array}{c}2.84 \mathrm{e}-05 \\
(4.84 \mathrm{e}-05)\end{array}$ & $\begin{array}{l}0.0740 * \\
(0.0394)\end{array}$ \\
\hline
\end{tabular}




\begin{tabular}{|c|c|c|c|c|c|}
\hline Log GDP per capita & $\begin{array}{c}0.221 \\
(0.161)\end{array}$ & $\begin{array}{c}0.689 * * * \\
(0.131)\end{array}$ & $\begin{array}{c}0.627 * * * \\
(0.157)\end{array}$ & $\begin{array}{c}0.930 * * * \\
(0.151)\end{array}$ & $\begin{array}{c}1.002^{* * *} \\
(0.149)\end{array}$ \\
\hline Democracy Dummy & $\begin{array}{l}-0.715 \\
(1.309)\end{array}$ & $\begin{array}{c}-3.227^{* *} \\
(1.523)\end{array}$ & $\begin{array}{c}-5.054^{* *} \\
(2.184)\end{array}$ & $\begin{array}{l}-0.635 \\
(1.164)\end{array}$ & $\begin{array}{l}7.876^{* *} \\
(3.369)\end{array}$ \\
\hline Time Trend & $\begin{array}{c}0.163 * * * \\
(0.0392)\end{array}$ & & & & \\
\hline $\begin{array}{l}\text { Capital Account } \\
\text { Openness }\end{array}$ & & $\begin{array}{c}0.414 * * * \\
(0.0822)\end{array}$ & & & \\
\hline Foreign Aid (logged) & & & $\begin{array}{c}0.166 * \\
(0.0851)\end{array}$ & & \\
\hline Internal Conflict & & & & $\begin{array}{c}-0.0376 \\
(0.0383)\end{array}$ & \\
\hline Workers’ Rights & & & & & $\begin{array}{c}0.00697 \\
(0.106)\end{array}$ \\
\hline Corruption & & & & & $\begin{array}{l}-0.0947 \\
(0.0948)\end{array}$ \\
\hline Country Fixed Effects & Yes & Yes & Yes & Yes & Yes \\
\hline Decade Dummies & Yes & Yes & Yes & Yes & Yes \\
\hline Observations & 511 & 504 & 484 & 399 & 499 \\
\hline R-squared & 0.992 & 0.992 & 0.990 & 0.993 & 0.991 \\
\hline Number of Countries & 74 & 71 & 73 & 57 & 74 \\
\hline
\end{tabular}

Table 26 Determinants of FDI Inflows: Strength of Enforcement Provisions in BITs

\begin{tabular}{lcc}
\hline BITs in Force & & \\
& 0.0262 & -0.0176 \\
Enforcement Strength of BITs & $(0.0273)$ & $(0.0202)$ \\
& 0.383 & -0.311 \\
BITs*Enforcement Strength & $(0.317)$ & $(0.246)$ \\
Rule of Law & $\mathbf{0 . 0 0 9 3 6}$ & $\mathbf{0 . 0 0 9 4 7}$ \\
& $\mathbf{( 0 . 0 1 7 3 )}$ & $\mathbf{( 0 . 0 0 8 3 2 )}$ \\
Log Population & $0.819^{* * *}$ & $(1.412$ \\
& $(0.235)$ & $\mathbf{( 1 . 0 5 8 )}$ \\
GDP Growth & $0.553^{* * *}$ & $(2.028)$ \\
& $(0.0831)$ & 0.0101 \\
& & $(0.0279)$
\end{tabular}


Life Expectancy

$-0.0351$

(0.0473)

Oil Rent (\% GDP)

0.00257

(0.0202)

Inflation

0.00827

(0.00731)

Log GDP per capita

$2.151 * * *$

(0.614)

Democracy Dummy

$-5.858$

(4.122)

Country Fixed Effects

Decade Dummies

$$
\text { No }
$$

Yes

Observations

Yes

Yes

R-squared

147

125

0.978

0.996

Number of Countries

Robust standard errors in parentheses *** $\mathrm{p}<0.01,{ }^{* *} \mathrm{p}<0.05,{ }^{*} \mathrm{p}<0.1$

Table 27 Determinants of FDI Inflows: BITs, Citizen Participation, and Formal Political Institutions

\begin{tabular}{|c|c|c|c|}
\hline & $(1)$ & $(2)$ & (3) \\
\hline BITs in force & $\begin{array}{l}-0.0157 \\
(0.0194)\end{array}$ & $\begin{array}{l}-0.0201 \\
(0.0183)\end{array}$ & $\begin{array}{l}-0.0157 \\
(0.0247)\end{array}$ \\
\hline PARCOMP & $\begin{array}{l}-0.312 * \\
(0.180)\end{array}$ & $\begin{array}{l}-0.236 \\
(0.198)\end{array}$ & $\begin{array}{c}-0.355^{* *} \\
(0.179)\end{array}$ \\
\hline BITs*PARCOMP & $\begin{array}{c}0.0201 * * * \\
(0.00566)\end{array}$ & $\begin{array}{c}0.0190 * * * \\
(0.00581)\end{array}$ & $\begin{array}{c}0.0165 * * * \\
(0.00568)\end{array}$ \\
\hline Veto Players & $\begin{array}{c}0.412 \\
(0.322)\end{array}$ & $\begin{array}{l}0.0737 \\
(0.375)\end{array}$ & \\
\hline BITs*Veto Players & & $\begin{array}{c}0.0178 \\
(0.0172)\end{array}$ & \\
\hline Parties & $\begin{array}{c}0.202 \\
(0.146)\end{array}$ & & $\begin{array}{c}0.108 \\
(0.153)\end{array}$ \\
\hline BITs*Parties & & & $\begin{array}{c}0.00913 \\
(0.00760)\end{array}$ \\
\hline Rule of Law & $\begin{array}{l}-0.0295 \\
(0.230)\end{array}$ & $\begin{array}{l}-0.0146 \\
(0.212)\end{array}$ & $\begin{array}{l}-0.153 \\
(0.228)\end{array}$ \\
\hline Log Population & $2.535 * * *$ & $2.459 * * *$ & $2.695 * * *$ \\
\hline & 110 & & \\
\hline
\end{tabular}




\begin{tabular}{|c|c|c|c|}
\hline & $(0.661)$ & $(0.660)$ & $(0.816)$ \\
\hline \multirow[t]{2}{*}{ GDP Growth } & -0.00524 & -0.00438 & 0.00452 \\
\hline & $(0.00938)$ & $(0.00934)$ & $(0.00925)$ \\
\hline \multirow[t]{2}{*}{ Life Expectancy } & $0.0788 * *$ & $0.0804 * * *$ & $0.0868 * * *$ \\
\hline & $(0.0313)$ & $(0.0311)$ & $(0.0336)$ \\
\hline \multirow[t]{2}{*}{ Oil Rent (\% GDP) } & -0.00997 & -0.00953 & $-0.0200 * *$ \\
\hline & $(0.00967)$ & $(0.00993)$ & $(0.00880)$ \\
\hline \multirow[t]{2}{*}{ Inflation } & $3.03 e-05$ & $2.82 \mathrm{e}-05$ & $2.16 e-05$ \\
\hline & $(4.76 e-05)$ & $(4.86 e-05)$ & $(4.95 e-05)$ \\
\hline \multirow[t]{2}{*}{ Log GDP per capita } & $1.063 * * *$ & $1.097 * * *$ & $0.746 * * *$ \\
\hline & $(0.166)$ & $(0.163)$ & $(0.148)$ \\
\hline \multirow[t]{2}{*}{ Democracy Dummy } & $1.058 * *$ & $3.433 * * *$ & $10.40 * * *$ \\
\hline & $(0.440)$ & $(0.741)$ & $(3.450)$ \\
\hline Observations & 452 & 452 & 511 \\
\hline R-squared & 0.992 & 0.991 & 0.992 \\
\hline Number of countries & 72 & 72 & 74 \\
\hline
\end{tabular}




\section{APPENDIX D}

Table 28 Countries in Sample in Surveys

\begin{tabular}{|l|c|c|}
\hline PEW Sample Countries & ASES Sample Countries & WVS Sample Countries \\
\hline Angola & China & Algeria \\
Bangladesh & Malaysia & Belarus \\
China & Singapore & Bosnia \\
Egypt & Taiwan & China \\
Ivory Coast & & Egypt \\
Jordan & & Iran \\
Lebanon & Iraq \\
Pakistan & & Jordan \\
Russia & & Kyrgyzstan \\
South Africa & & Morocco \\
Tanzania & & Pakistan \\
Uganda & & Peru \\
Uzbekistan & & Russia \\
Vietnam & & Saudi Arabia \\
& & Singapore \\
& & South Africa \\
& & Tanzania \\
& & Uganda \\
& & Vietnam \\
& & Zimbabwe \\
\hline
\end{tabular}

Table 29 Variable Descriptions for WVS Survey Models

\begin{tabular}{|l|l|l|l|l|l|}
\hline Variable & Mean & Median & $\begin{array}{l}\text { St. } \\
\text { Dev. }\end{array}$ & Definition & Source \\
\hline & & & & 1: not elementary & \\
& & & 2: elementary & \\
& & & 3: not technical & \\
& & & 4: technical & \\
& & & 5: not secondary & World Values \\
& & & 6: secondary & Survey \\
Education & 4.06 & 4 & 2.29 & 7: not university & $(2000)$ \\
\hline
\end{tabular}




\begin{tabular}{|c|c|c|c|c|c|}
\hline & & & & 8: university & \\
\hline $\begin{array}{l}\text { GDP } \\
\text { Growth }\end{array}$ & 4.33 & 4.86 & 3.53 & GDP growth (annual \%) & $\begin{array}{ll}\text { World } & \text { Bank } \\
\text { (2011) } & \end{array}$ \\
\hline $\begin{array}{l}\text { Governme } \\
\text { nt } \\
\text { Confidenc } \\
\text { e }\end{array}$ & 2.65 & 3 & 1.02 & $\begin{array}{l}\text { "For each one, could you tell me how much } \\
\text { confidence you have in them: is it a great deal } \\
\text { of confidence, quite a lot of confidence, not } \\
\text { very much confidence or none at all? The } \\
\text { government" } \\
\text { 1: none at all } \\
\text { 2: not very much } \\
\text { 3: quite a lot } \\
\text { 4: a great deal }\end{array}$ & $\begin{array}{l}\text { World Values } \\
\text { Survey } \\
(2000)\end{array}$ \\
\hline Income & 4.53 & 4 & 2.26 & $\begin{array}{l}\text { Income Scale } \\
\text { 1: Low } \\
\text { 10: High }\end{array}$ & $\begin{array}{l}\text { World Values } \\
\text { Survey } \\
(2000)\end{array}$ \\
\hline $\begin{array}{l}\text { FDI } \\
\text { Inflows } \\
\text { (\% GDP) }\end{array}$ & 2.18 & 0.80 & 4.07 & $\begin{array}{l}\text { Foreign direct investment, net inflows } \\
\text { (percent of GDP) }\end{array}$ & $\begin{array}{l}\text { World Bank } \\
\text { (2011) }\end{array}$ \\
\hline $\begin{array}{l}\text { Life } \\
\text { Expectanc } \\
\mathrm{y}\end{array}$ & 66.17 & 68.68 & 8.00 & $\begin{array}{l}\text { Life expectancy at birth indicates the number } \\
\text { of years a newborn infant would live if } \\
\text { prevailing patterns of mortality at the time of } \\
\text { its birth were to stay the same throughout its } \\
\text { life. }\end{array}$ & $\begin{array}{l}\text { World Bank } \\
(2011)\end{array}$ \\
\hline Male & 0.49 & 0 & 0.50 & $\begin{array}{l}1 \text { if male } \\
0 \text { if female }\end{array}$ & $\begin{array}{l}\text { World Values } \\
\text { Survey } \\
(2000)\end{array}$ \\
\hline $\begin{array}{l}\text { Rule of } \\
\text { Law }\end{array}$ & -0.42 & -0.43 & 0.64 & $\begin{array}{l}\text { Rule of law captures perceptions of the extent } \\
\text { to which agents have confidence in and abide } \\
\text { by the rules of society, and in particular the } \\
\text { quality of contract enforcement, property } \\
\text { rights, the police, and the courts, as well as } \\
\text { the likelihood of crime and violence. }\end{array}$ & $\begin{array}{l}\text { World Bank. } \\
\text { World } \\
\text { Governance } \\
\text { Indicators } \\
(2010)\end{array}$ \\
\hline
\end{tabular}

Table 30 Variable Descriptions for Panel Regression Models

\begin{tabular}{|l|l|l|l|l|l|}
\hline Variable & Mean & Median & St. Dev. & Definition & Source \\
\hline & & & $\begin{array}{l}\text { Net official development assistance and } \\
\text { official aid received (current US dollars) } \\
\text { (logged) } \\
\text { Net official development assistance is } \\
\text { disbursement flows (net of repayment of } \\
\text { principal) that meet the DAC definition } \\
\text { of ODA and are made to countries and } \\
\text { territories on the DAC list of aid } \\
\text { recipients. Net official aid refers to aid } \\
\text { flows (net of repayments) from official } \\
\text { donors to countries and territories in part } \\
\text { II of the DAC list of recipients: more } \\
\text { advanced countries of Central and }\end{array}$ & World Bank \\
Aid & 18.18 & 18.44 & 1.92 & & \\
\hline
\end{tabular}




\begin{tabular}{|c|c|c|c|c|c|}
\hline & & & & $\begin{array}{l}\text { Eastern Europe, the countries of the } \\
\text { former Soviet Union, and certain } \\
\text { advanced developing countries and } \\
\text { territories. }\end{array}$ & \\
\hline BITs in force & 3.72 & 1 & 8.77 & $\begin{array}{l}\text { Total number of BITs that have been } \\
\text { entered into force }\end{array}$ & $\begin{array}{l}\text { UNCTAD } \\
(2011)\end{array}$ \\
\hline $\begin{array}{l}\text { Capital } \\
\text { Account } \\
\text { Openness }\end{array}$ & -0.34 & -1.15 & 1.44 & $\begin{array}{l}\text { KAOPEN is based on the binary dummy } \\
\text { variables that codify the tabulation of } \\
\text { restrictions on cross-border financial } \\
\text { transactions reported in the IMF's Annual } \\
\text { Report on Exchange Arrangements and } \\
\text { Exchange Restrictions (AREAER). }\end{array}$ & $\begin{array}{l}\text { Chinn and } \\
\text { Ito (2009) }\end{array}$ \\
\hline Corruption & -0.46 & -0.58 & 0.74 & $\begin{array}{l}\text { Control of Corruption captures } \\
\text { perceptions of the extent to which public } \\
\text { power is exercised for private gain, } \\
\text { including both petty and grand forms of } \\
\text { corruption, as well as "capture" of the } \\
\text { state by elites and private interests. The } \\
\text { range is from - } 2.5 \text { to } 2.5 \text {, with higher } \\
\text { values corresponding to better } \\
\text { governance outcomes. }\end{array}$ & $\begin{array}{l}\text { World Bank. } \\
\text { World } \\
\text { Governance } \\
\text { Indicators } \\
(2010)\end{array}$ \\
\hline $\begin{array}{l}\text { Democracy } \\
\text { Dummy }\end{array}$ & 0.42 & 0 & 0.49 & $\begin{array}{l}1 \text { if ever a democracy, } 0 \text { otherwise } \\
\text { Democracy is conceived as three } \\
\text { essential, interdependent elements. One is } \\
\text { the presence of institutions and } \\
\text { procedures through which citizens can } \\
\text { express effective preferences about } \\
\text { alternative policies and leaders. Second is } \\
\text { the existence of institutionalized } \\
\text { constraints on the exercise of power by } \\
\text { the executive. Third is the guarantee of } \\
\text { civil liberties to all citizens in their daily } \\
\text { lives and in acts of political participation. } \\
\text { Other aspects of plural democracy, such } \\
\text { as the rule of law, systems of checks and } \\
\text { balances, freedom of the press, and so on } \\
\text { are means to, or specific manifestations } \\
\text { of, these general principles. }\end{array}$ & $\begin{array}{l}\text { Marshall and } \\
\text { Gurr (2008) }\end{array}$ \\
\hline FDI (\% GDP) & 2.46 & 0.84 & 6.39 & $\begin{array}{l}\text { Foreign Direct Investment Inflows as a } \\
\text { Percent of GDP. See FDI inflows } \\
\text { (logged) for further details }\end{array}$ & $\begin{array}{l}\text { World Bank } \\
\text { (2011) }\end{array}$ \\
\hline $\begin{array}{l}\text { FDI Inflows } \\
\text { (logged) }\end{array}$ & 17.53 & 17.62 & 2.79 & $\begin{array}{l}\text { Log of Foreign direct investment, net } \\
\text { inflows (BoP, current US\$) } \\
\text { Foreign direct investment is net inflows } \\
\text { of investment to acquire a lasting interest } \\
\text { in or management control over an } \\
\text { enterprise operating in an economy other } \\
\text { than that of the investor. It is the sum of } \\
\text { equity capital, reinvested earnings, other }\end{array}$ & $\begin{array}{l}\text { World Bank } \\
\text { (2011) }\end{array}$ \\
\hline
\end{tabular}




\begin{tabular}{|c|c|c|c|c|c|}
\hline & & & & $\begin{array}{l}\text { long-term capital, and short-term capital, } \\
\text { as shown in the balance of payments. }\end{array}$ & \\
\hline $\begin{array}{l}\text { Freedom of } \\
\text { Assembly }\end{array}$ & 0.56 & 0.71 & 0 & $\begin{array}{l}\text { Right of citizens to assemble freely and } \\
\text { to associate with other persons in } \\
\text { political parties, trade unions, cultural } \\
\text { organizations, or other special-interest } \\
\text { groups. } \\
\text { Scores: } \\
\text { 0: denied or restricted } \\
\text { 1: limited } \\
\text { 2: unrestricted }\end{array}$ & CIRI (2008) \\
\hline GDP growth & 4.07 & 4.28 & 7.65 & $\begin{array}{l}\text { GDP growth (annual \%) } \\
\text { GDP is the sum of gross value added by } \\
\text { all resident producers in the economy } \\
\text { plus any product taxes and minus any } \\
\text { subsidies not included in the value of the } \\
\text { products. }\end{array}$ & $\begin{array}{l}\text { World Bank } \\
\text { (2011) }\end{array}$ \\
\hline $\begin{array}{l}\text { GDP per } \\
\text { capita }\end{array}$ & 6.78 & 6.56 & 1.35 & $\begin{array}{l}\text { GDP per capita is gross domestic product } \\
\text { divided by midyear population. GDP is } \\
\text { the sum of gross value added by all } \\
\text { resident producers in the economy plus } \\
\text { any product taxes and minus any } \\
\text { subsidies not included in the value of the } \\
\text { products. It is calculated without making } \\
\text { deductions for depreciation of fabricated } \\
\text { assets or for depletion and degradation of } \\
\text { natural resources. Data are in current } \\
\text { U.S. dollars. (logged) }\end{array}$ & $\begin{array}{l}\text { World Bank } \\
\text { (2011) }\end{array}$ \\
\hline Inflation & 50.88 & 8.10 & 714.04 & $\begin{array}{l}\text { Inflation, consumer prices (annual \%) } \\
\text { Inflation as measured by the consumer } \\
\text { price index reflects the annual percentage } \\
\text { change in the cost to the average } \\
\text { consumer of acquiring a basket of goods } \\
\text { and services that may be fixed or } \\
\text { changed at specified intervals, such as } \\
\text { yearly. }\end{array}$ & $\begin{array}{l}\text { World Bank } \\
\text { (2011) }\end{array}$ \\
\hline $\begin{array}{l}\text { Internal } \\
\text { Conflict }\end{array}$ & 7.94 & 8.25 & 2.76 & $\begin{array}{l}\text { Assessment of political violence } \\
\text { including the following components: civil } \\
\text { war/coup threat, terrorism/political } \\
\text { violence, and civil disorder. } \\
\text { High values indicate low levels of } \\
\text { conflict. }\end{array}$ & $\begin{array}{l}\text { Political } \\
\text { Risk } \\
\text { Services } \\
\text { (2011) }\end{array}$ \\
\hline Legislature & 1.52 & 2 & 0.79 & $\begin{array}{l}\text { Mode of legislative selection } \\
0 \text { : no legislature } \\
\text { 1: non-elective legislature } \\
\text { 2: elective legislature }\end{array}$ & $\begin{array}{l}\text { Cheibub, } \\
\text { Gandhi, and } \\
\text { Vreeland } \\
\text { (2009) }\end{array}$ \\
\hline $\begin{array}{l}\text { Life } \\
\text { expectancy }\end{array}$ & 59.34 & 10.58 & 60.46 & $\begin{array}{l}\text { Life expectancy at birth indicates the } \\
\text { number of years a newborn infant would } \\
\text { live if prevailing patterns of mortality at } \\
\text { the time of its birth were to stay the same }\end{array}$ & $\begin{array}{l}\text { World Bank } \\
\text { (2011) }\end{array}$ \\
\hline
\end{tabular}




\begin{tabular}{|c|c|c|c|c|c|}
\hline & & & & throughout its life. & \\
\hline $\begin{array}{l}\text { Oil rent (\% } \\
\text { GDP) }\end{array}$ & 7.88 & 0 & 16.31 & $\begin{array}{l}\text { Oil rents (\% of GDP) } \\
\text { Oil rents are the difference between the } \\
\text { value of crude oil production at world } \\
\text { prices and total costs of production. }\end{array}$ & $\begin{array}{l}\text { World Bank } \\
(2011)\end{array}$ \\
\hline PARCOMP & 1.80 & 1 & 1.00 & $\begin{array}{l}\text { The competitiveness of participation } \\
\text { refers to the extent to which alternative } \\
\text { preferences for policy and leadership can } \\
\text { be pursued in the political arena. Political } \\
\text { competition implies a significant degree } \\
\text { of civil interaction. } \\
1 \text { Repressed, } 2 \text { Suppressed, } 3 \text { Factional, } 4 \\
\text { Transitional, } 5 \text { Competitive }\end{array}$ & $\begin{array}{l}\text { Marshall and } \\
\text { Gurr (2008) }\end{array}$ \\
\hline PARREG & 3.62 & 4 & 0.67 & $\begin{array}{l}\text { PARREG measures the degree of } \\
\text { organization and institutionalization of } \\
\text { participation. } \\
\text { 1: Unregulated } \\
\text { 2: Multiple Identity } \\
\text { 3: Sectarian } \\
\text { 4: Restricted } \\
\text { 5: Regulated }\end{array}$ & $\begin{array}{l}\text { Marshall and } \\
\text { Gurr (2008) }\end{array}$ \\
\hline Parties & 1.03 & 1 & 0.84 & $\begin{array}{l}\text { Parties within the legislature } \\
0 \text { : Either no legislature or all members of } \\
\text { the } \\
\text { legislature are nonpartisan } \\
\text { 1: Legislature with only members from } \\
\text { the regime party } \\
\text { 2: Legislature with multiple parties }\end{array}$ & $\begin{array}{l}\text { Cheibub, } \\
\text { Gandhi, and } \\
\text { Vreeland } \\
\text { (2009) }\end{array}$ \\
\hline Political Risk & 56.02 & 57.08 & 14.14 & $\begin{array}{l}\text { Political risk includes the following } \\
\text { components: government stability, } \\
\text { socioeconomic conditions, investment } \\
\text { profile, internal conflict, external } \\
\text { conflict, corruption, military in politics, } \\
\text { religion in politics, law and order, ethnic } \\
\text { tensions, democratic accountability, and } \\
\text { bureaucracy quality. } \\
\text { Higher values indicate lower political } \\
\text { risk. }\end{array}$ & $\begin{array}{l}\text { Political } \\
\text { Risk } \\
\text { Services } \\
\text { (2011) }\end{array}$ \\
\hline Population & 15.25 & 15.44 & 1.99 & $\begin{array}{l}\text { Total Population (logged) } \\
\text { Total population is based on the de facto } \\
\text { definition of population, which counts all } \\
\text { residents regardless of legal status or } \\
\text { citizenship--except for refugees not } \\
\text { permanently settled in the country of } \\
\text { asylum, who are generally considered } \\
\text { part of the population of their country of } \\
\text { origin. }\end{array}$ & $\begin{array}{l}\text { World Bank } \\
\text { (2011) }\end{array}$ \\
\hline Rule of Law & -0.60 & -0.70 & 0.78 & $\begin{array}{l}\text { Rule of law captures perceptions of the } \\
\text { extent to which agents have confidence in } \\
\text { and abide by the rules of society, and in }\end{array}$ & $\begin{array}{l}\text { World Bank. } \\
\text { World } \\
\text { Governance }\end{array}$ \\
\hline
\end{tabular}




\begin{tabular}{|c|c|c|c|c|c|}
\hline & & & & $\begin{array}{l}\text { particular the quality of contract } \\
\text { enforcement, property rights, the police, } \\
\text { and the courts, as well as the likelihood } \\
\text { of crime and violence. }\end{array}$ & $\begin{array}{l}\text { Indicators } \\
(2010)\end{array}$ \\
\hline $\begin{array}{l}\text { Workers' } \\
\text { Rights }\end{array}$ & 0.58 & 0 & 0.68 & $\begin{array}{l}\text { Freedom of association for workers at } \\
\text { their workplaces and the right to bargain } \\
\text { collectively with their employers. } \\
\text { Scores: } \\
\text { 0: severely restricted } \\
\text { 1: somewhat restricted } \\
\text { 2: fully protected }\end{array}$ & CIRI (2008) \\
\hline Veto Players & 0.12 & 0 & 0.24 & $\begin{array}{l}\text { Measure of political constraints to policy } \\
\text { change based on the number of } \\
\text { independent branches of government } \\
\text { with veto power over policy change. }\end{array}$ & $\begin{array}{l}\text { Henisz } \\
(2000)\end{array}$ \\
\hline
\end{tabular}

Table 31 Countries in Sample in Panel Regressions

\begin{tabular}{|lll|}
\hline Algeria & Guinea-Bissau & Oman \\
Angola & Guyana & Pakistan \\
Azerbaijan & Haiti & Peru \\
Bahrain & Indonesia & Qatar \\
Bangladesh & Iran & Russia \\
Belarus & Iraq & Rwanda \\
Botswana & Jordan & Saudi Arabia \\
Burkina Faso & Kazakhstan & Senegal \\
Burundi & Kenya & Singapore \\
Cambodia & Kuwait & South Africa \\
Cameroon & Kyrgyzstan & Sudan \\
CAR & Laos & Swaziland \\
Chad & Lebanon & Syria \\
China & Lesotho & Tajikistan \\
Comoros & Liberia & Tanzania \\
Congo, DR & Libya & Thailand \\
Congo, Republic & Malaysia & Togo \\
Cote d'Ivoire & Mauritania & Tunisia \\
Cuba & Mexico & Turkmenistan \\
Djibouti & Montenegro & Uganda \\
Egypt & Morocco & UAE \\
Equatorial Guinea & Mozambique & Uzbekistan \\
Eritrea & Myanmar & Vietnam \\
Ethiopia & Nambia & Yemen \\
Gabon & Nepal & Zambia \\
Gambia & Niger & Zimbabwe \\
Georgia & Nigeria & \\
Guinea & North Korea & \\
\hline
\end{tabular}




\section{APPENDIX E}

\section{E.1 SURVEY QUESTIONAIRE}

The purpose of this research study is to analyze foreign direct investment (FDI) in the developing world. I am researching how developing nations can open their markets to FDI. For that reason, I am surveying investors and business professionals who have experiences abroad. The survey will take approximately 10 minutes. If you are willing to participate, my survey will ask about your experiences in and preferences for investing in the developing world. There are no foreseeable bsks associated with this project. Survey responses will not be identifiable through the online survey adminstration. Thus, all survey responses are confidential. Your participation is voluntary, and you may withdraw from this projectert any time. I, Ida Bastiaens, am conducting this study. If you have any questions, I can be reached at 412-334-1086 o ik @i i t.edu. The finalfisul ts o uthis sr vey and a copy of my dissertation will be available upon request. 
1. Which of the following best describes the industry of the company for which you work? (Check all that apply)

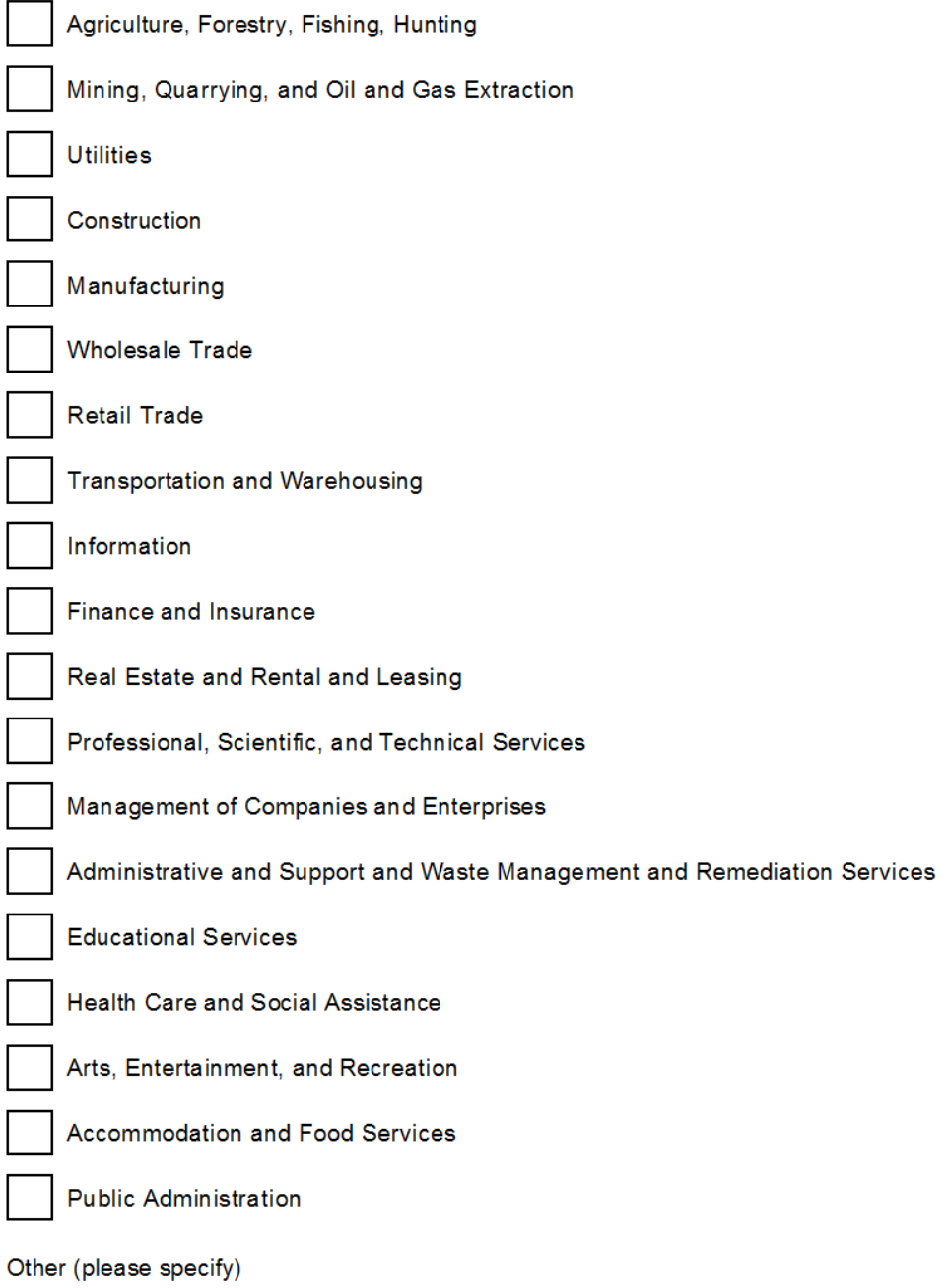

2. What is your business title? 
3. What is the annual revenue range of your company?
$\bigcirc<\$ 1$ million
$\bigcirc \$ 1$ million $<\$ 5$ million
$\bigcirc \$ 5$ million $<\$ 10$ million
$\bigcirc \$ 10$ million $<\$ 50$ million
$\bigcirc \$ 50$ million $<\$ 100$ million
$\bigcirc \$ 100$ million $<\$ 500$ million
$\bigcirc \$ 500$ million $<\$ 1$ billion
$\bigcirc \$ 1$ billion $<\$ 2$ billion
$\bigcirc \$ 2$ billion $<\$ 5$ billion
$\bigcirc \$ 5$ billion or more

4. What is the annual revenue range of your company from operations in developing countries?

$\bigcirc<\$ 1$ million

$\bigcirc \$ 1$ million $<\$ 5$ million

$\bigcirc \$ 5$ million $<\$ 10$ million

$\bigcirc \$ 10$ million $<\$ 50$ million

$\bigcirc \$ 50$ million $<\$ 100$ million

$\bigcirc \$ 100$ million $<\$ 500$ million

$\bigcirc \$ 500$ million $<\$ 1$ billion

$\bigcirc \$ 1$ billion $<\$ 2$ billion

$\bigcirc \$ 2$ billion $<\$ 5$ billion

$\bigcirc \$ 5$ billion or more 


\section{How many full-time employees does your company have?}
100 or less
101-500 employees
(501-1,000 employees
1,001-5,000 employees
(5,001-10,000 employees
(10,001-20,000 employees
20,001-30,000 employees
30,001-40,000 employees
( 40,001-50,000 employees
More than 50,000 employees

\section{Where is your company headquartered?}
Canada
$\bigcirc$ United States
Mexico
Central America
South America
$\bigcirc$ Eastern Europe
$\bigcirc$ Western Europe
Sub-Saharan Africa
North Africa
Middle East
Russia
Central Asia
East Asia
$\bigcirc$ South Asia
$\bigcirc$ South East Asia
Japan
Australia or New Zealand
Other (please specify) 
7. How would you best describe your role in the company's decision-making process to expand operations abroad?

O lam the sole decision maker

I make the final decision with input from staff/management

I help reach the final decision as part of a group/committee

O I provide input toward the final decision

O have no input into the final decision

The boundary of the company includes all activities that are internal to a single legal entity, not including joint ventures. Operations include the building, expansion, or maintenance of production or distribution facilities.

8. Does your company currently have operations in developing countries? (NOT: Western Europe, United States, Canada, Australia, Japan)

Yes

No

9. Did your company have operations in developing countries in the past?
Yes
No

10. Why doesn't your company currently have operations in developing countries?

$\square$ Lack of judicial independence

Government interference in business operations

Customer base is in developed countries

Political instability

Weak property right protections

Other (please specify) 
11. The following is a list of authoritarian countries. In which countries does your com have operations? (check all that apply)

\begin{tabular}{|c|}
\hline Algeria \\
\hline Angola \\
\hline Armenia \\
\hline Azerbaijan \\
\hline Bahrain \\
\hline Bangladesh \\
\hline Belarus \\
\hline Bhutan \\
\hline Burkina Faso \\
\hline Cambodia \\
\hline Cameroon \\
\hline Central African Republic \\
\hline Chad \\
\hline China \\
\hline Congo Brazzaville \\
\hline Congo Kinshasa \\
\hline Cuba \\
\hline Djibouti \\
\hline Egypt \\
\hline Equatorial Guinea \\
\hline Eritrea \\
\hline Ethiopia \\
\hline
\end{tabular}




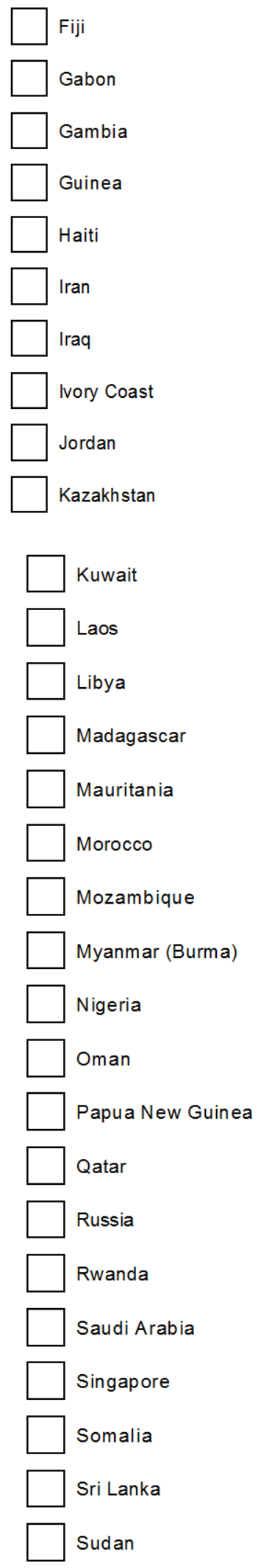




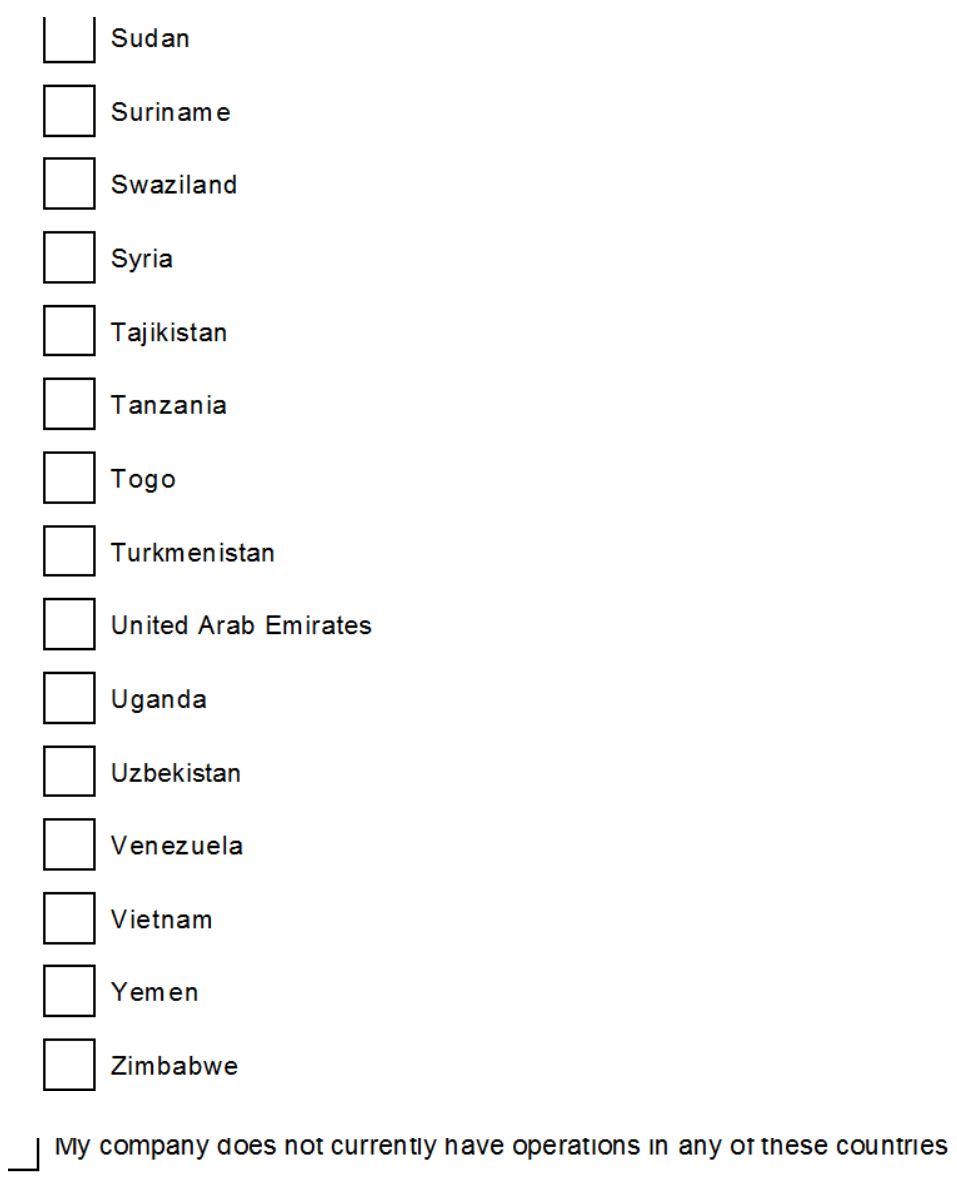

12. Did your company have operations in authoritarian countries in the past?

Yes

No

13. Why doesn't your company currently have operations in any authoritarian countries?

$\square$ Lack of judicial in dependence

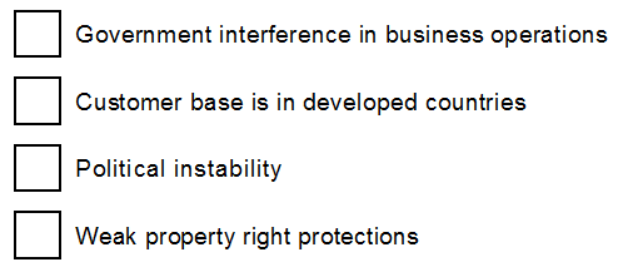

Other (please specify)

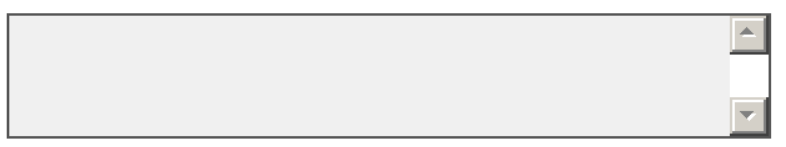


14. What is the annual revenue range of your company from operations in authoritarian countries?
$\bigcirc<\$ 1$ million
$\bigcirc \$ 1$ million $<\$ 5$ million
$\bigcirc \$ 5$ million $<\$ 10$ million
$\bigcirc \$ 10$ million $<\$ 50$ million
$\bigcirc \$ 50$ million $<\$ 100$ million
$\bigcirc \$ 100$ million $<\$ 500$ million
$\bigcirc \$ 500$ million $<\$ 1$ billion
$\bigcirc \$ 1$ billion $<\$ 2$ billion
$\bigcirc 2$ billion $<\$ 5$ billion
$\bigcirc \$ 5$ billion or more

15. Please choose one authoritarian country selected in question 9 . Please type the name of this country in box below.

Unless specified, property rights do not include intellectual property.

16. Currently, how risky to the following dimensions of your business is having operations in [Q15]?

Intellectual Property Right
Security
Eontract Security
Estaplishmenty Right S curity
Rights


The United Nations defines bilateral investment treaties as agreements between two countries for the reciprocal encouragement, promotion and protection of investments in each other's territories by companies based in either country.

Academics define freedom of association as the right of citizens to assemble freely and associate with other persons in political parties, cultural organizations, trade associations, and other special-interest groups.

\section{Currently, how valuable to ensuring secure property right protections are the following} for your company in [Q15]?

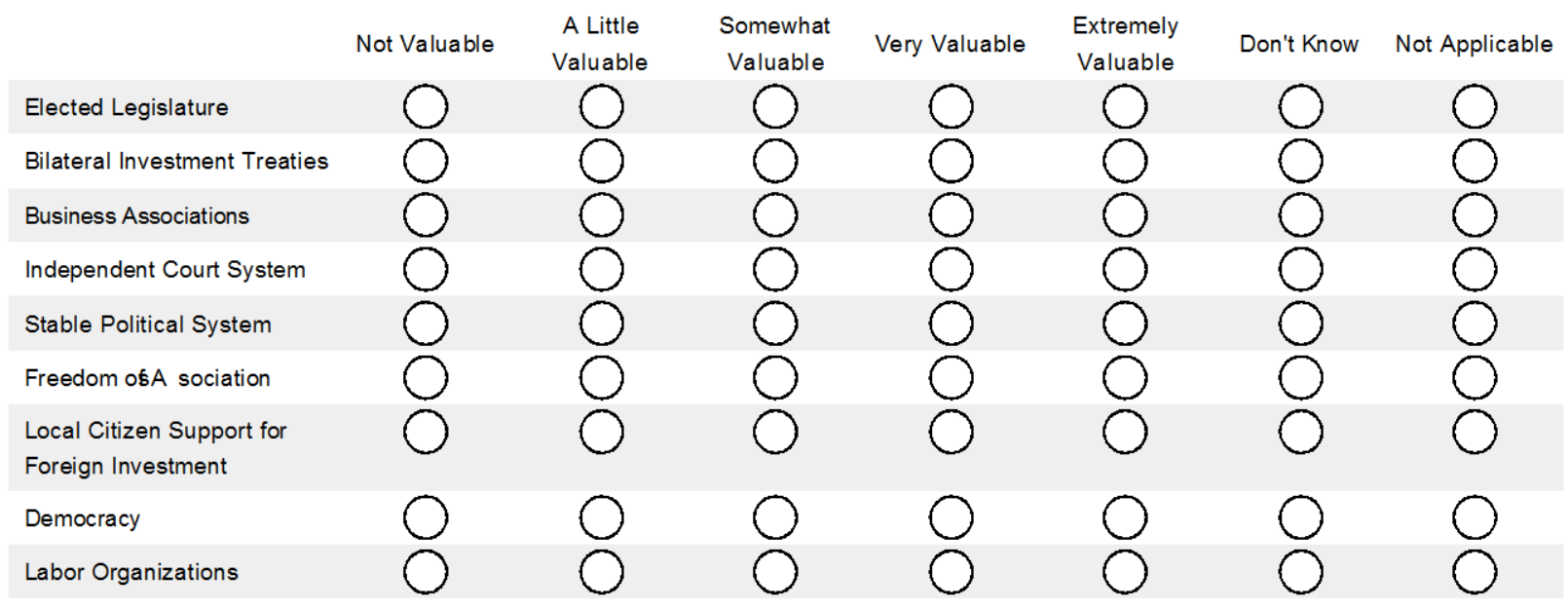

18. Currently, how valuable to ensuring profitable operations are the following for your company in [Q15]?

\begin{tabular}{|c|c|c|c|c|c|c|c|}
\hline & Not Valuable & $\begin{array}{c}\text { A Little } \\
\text { Valuable }\end{array}$ & $\begin{array}{l}\text { Somewhat } \\
\text { Valuable }\end{array}$ & Very Valuable & $\begin{array}{l}\text { Extremely } \\
\text { Valuable }\end{array}$ & Don't Know & Not Applicable \\
\hline \multicolumn{8}{|c|}{ Bilateral Investment Treaties } \\
\hline \multicolumn{8}{|l|}{ Elected Legislature } \\
\hline \multicolumn{8}{|l|}{ Labor Organizations } \\
\hline \multicolumn{8}{|l|}{ Democracy } \\
\hline \multicolumn{8}{|l|}{ Freedom o\$A sociation } \\
\hline \multicolumn{8}{|l|}{ Independent Court System } \\
\hline \multicolumn{8}{|l|}{ Business Associations } \\
\hline \multicolumn{8}{|l|}{$\begin{array}{l}\text { Local Citizen Support for } \\
\text { Foreign Investment }\end{array}$} \\
\hline Stable Political System & & & & & & & \\
\hline
\end{tabular}


Academics define liberal economic policies as policies that emphasize and support the market, market competition, supply and demand, and openness to international trade and investment.

19. Currently, how valuable are bilateral investment treaties signed by [Q15] in signaling this country's commitment to liberal economic policies?
Not Valuable
A Little Valuable
Somewhat Valuable
( Very Valuable
Extremely Valuable
Don't Know
Not Applicable

20. In [Q15] in the past five years, how often does your company work with the following organizations?

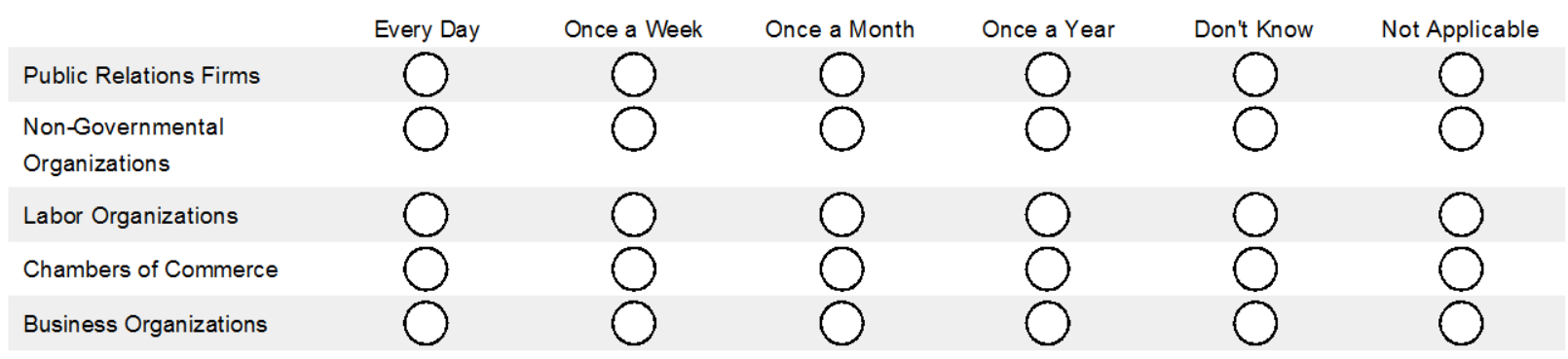

21. In [Q15] in the past five years, how often does your company engage in the following activities?

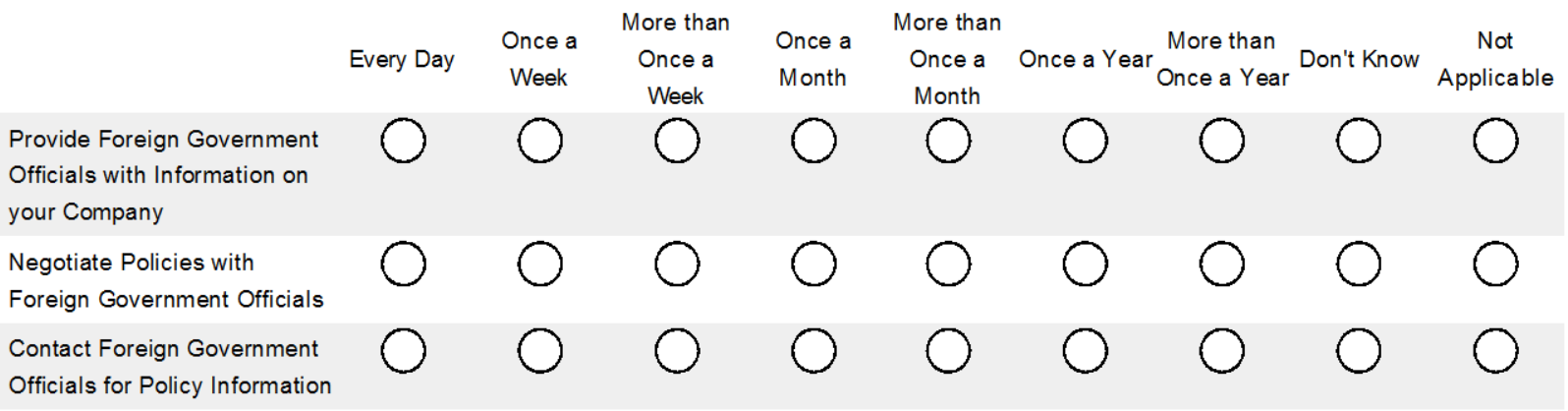


22. Currently, how valuable are local business associations in providing the following services to your company in [Q15]?

Information on Host Country
Markets
Information on Host Country
Regulations
Access to Government
Networks
Access to Business Networks

23. Currently, in [Q15], how strong is citizen support for foreign investment?

Very Weak

Weak

Moderate

Strong

Very Strong

$\bigcirc$ Don't Know

Not Applicable

\section{Please provide any additional comments or concerns.}

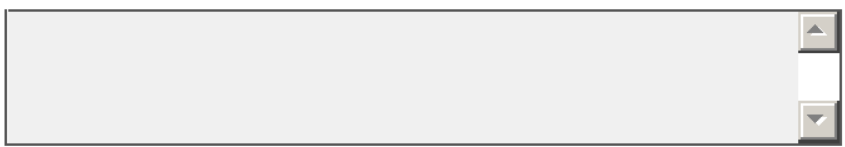

Thank you so much for your participation.

Please contact me if you have any questions or if you would like to provide additional information on your responses.

Ida Bastiaens

Doctoral Candidate

University of Pittsburgh

ikb1@pitt.edu

412-334-1086 


\section{E.2 SURVEY RESULTS}

1. Which of the following best describes the industry of the company for which you work? (Check all that apply)

\section{Answer Options}

Agriculture, Forestry, Fishing, Hunting

Mining, Quarrying, and Oil and Gas Extraction

Utilities

Construction

Manufacturing

Wholesale Trade

Retail Trade

Transportation and Warehousing

Information

Finance and Insurance

Real Estate and Rental and Leasing

Professional, Scientific, and Technical Services

Management of Companies and Enterprises

Administrative and Support and Waste Management and

Remediation Services

Educational Services

Health Care and Social Assistance

Arts, Entertainment, and Recreation

Accommodation and Food Services

Public Administration

Other (please specify)

\section{Response \\ Percent \\ Response
Count}

$0.0 \% \quad 0$

$4.1 \% \quad 2$

$0.0 \% \quad 0$

$4.1 \% \quad 2$

$44.9 \% \quad 22$

$6.1 \% \quad 3$

$0.0 \% \quad 0$

$0.0 \% \quad 0$

$22.4 \% \quad 11$

$6.1 \% \quad 3$

$0.0 \% \quad 0$

$16.3 \% \quad 8$

$4.1 \% \quad 2$

$0.0 \% \quad 0$

$0.0 \% \quad 0$

$0.0 \% \quad 0$

$0.0 \% \quad 0$

$0.0 \% \quad 0$

$0.0 \% \quad 0$

11

\section{Number Response Date}

1
2
3

4
5
6
7
8
9
10
11

\section{Other (please specify) Categories}

Feb 26, 2013 5:34 PM Feb 26, 2013 3:01 PM Feb 12, 2013 4:17 PM

Feb 12, 2013 3:41 PM

Feb 12, 2013 2:22 PM Jan 30, 2013 9:37 PM Jan 30, 2013 8:01 PM Jan 30, 2013 5:38 PM Jan 30, 2013 4:36 PM Jan 30, 2013 1:46 PM Jan 30, 2013 1:30 PM law software

Software \& Telecom Engineering products (Software for Chip Design)

Mobile service provider

Semiconductor equipment

Advertising and Media

life science tools

Marketing/Advertising

Analytical / Photonics

Telecommunications

\section{What is your business title?}




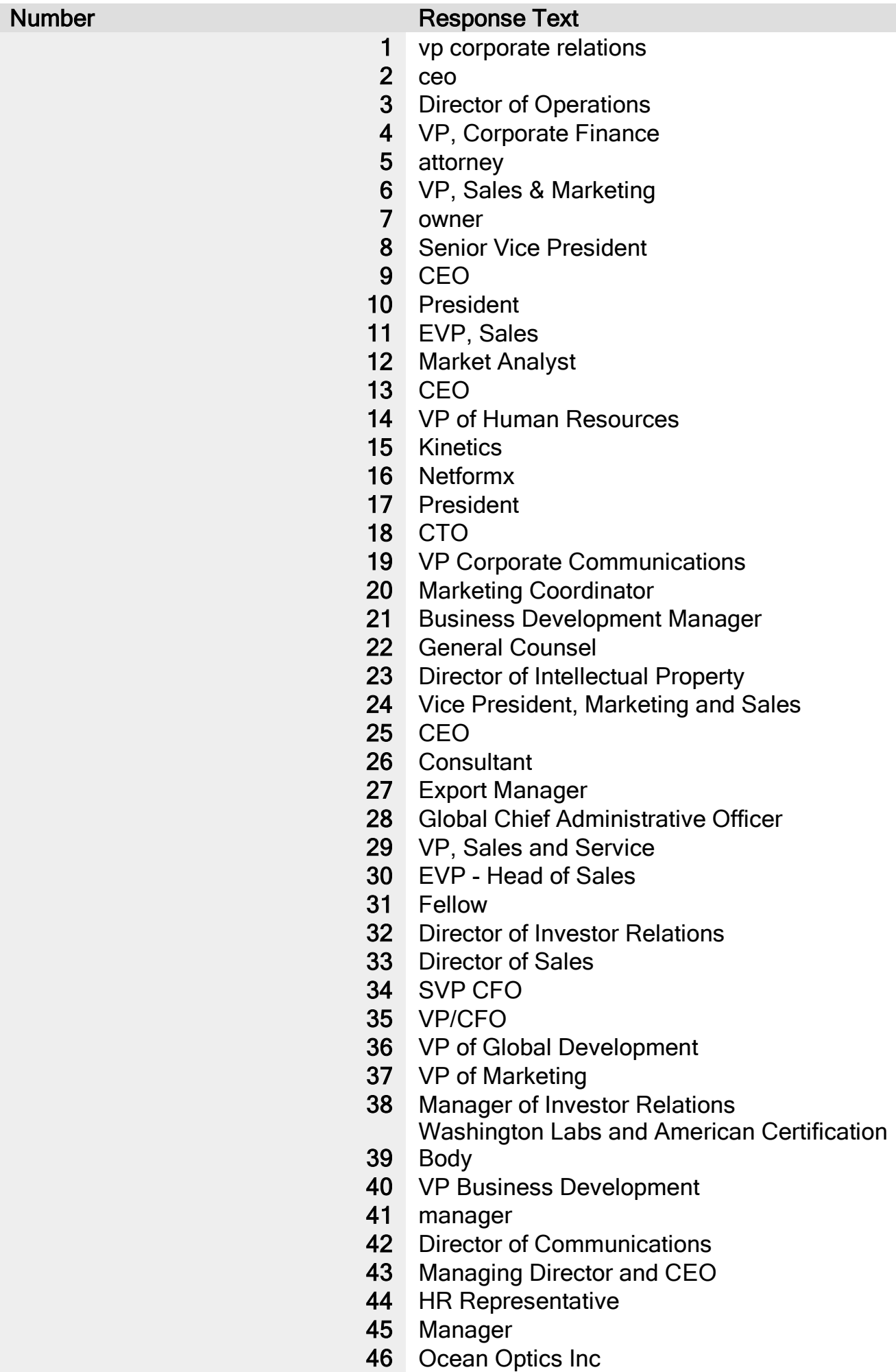


47 CFO

48 EVP

49 General Manager

\section{What is the annual revenue range of your company?}

\section{Answer Options}

$<\$ 1$ million

$\$ 1$ million $<\$ 5$ million

$\$ 5$ million $<\$ 10$ million

$\$ 10$ million $<\$ 50$ million

$\$ 50$ million $<\$ 100$ million

$\$ 100$ million $<\$ 500$ million

$\$ 500$ million $<\$ 1$ billion

$\$ 1$ billion $<\$ 2$ billion

$\$ 2$ billion $<\$ 5$ billion

$\$ 5$ billion or more

\section{Response \\ Percent \\ Response Count}

$2.1 \%$

$4.2 \%$

$8.3 \%$

$29.2 \%$

$6.3 \%$

$25.0 \%$

$8.3 \%$

$8.3 \%$

$8.3 \%$

$0.0 \%$

answered question

skipped question

4. What is the annual revenue range of your company from operations in developing countries?

\section{Answer Options}

$<\$ 1$ million

$\$ 1$ million $<\$ 5$ million

$\$ 5$ million $<\$ 10$ million

$\$ 10$ million $<\$ 50$ million

$\$ 50$ million < $\$ 100$ million

$\$ 100$ million $<\$ 500$ million

$\$ 500$ million $<\$ 1$ billion

$\$ 1$ billion $<\$ 2$ billion

$\$ 2$ billion $<\$ 5$ billion

$\$ 5$ billion or more

Response Response

Percent Count

$31.9 \%$

$8.5 \%$

$17.0 \%$

$21.3 \%$

$4.3 \%$

$12.8 \%$

$2.1 \%$

$2.1 \%$

$0.0 \%$

$0.0 \%$

answered question

skipped question

\section{How many full-time employees does your company have?}

\section{Answer Options}

100 or less

101-500 employees

501-1,000 employees

$1,001-5,000$ employees

$\begin{array}{cc}\begin{array}{c}\text { Response } \\ \text { Percent }\end{array} & \begin{array}{c}\text { Response } \\ \text { Count }\end{array} \\ 30.6 \% & 15 \\ 28.6 \% & 14 \\ 8.2 \% & 4 \\ 26.5 \% & 13\end{array}$


$5,001-10,000$ employees

10,001-20,000 employees

20,001-30,000 employees

$30,001-40,000$ employees

40,001-50,000 employees

More than 50,000 employees
$4.1 \%$

$2.0 \%$

$0.0 \%$

$0.0 \%$

$0.0 \%$

$0.0 \%$

answered question

skipped question

\section{Where is your company headquartered?}

Answer Options
Canada
United States
Mexico
Central America
South America
Eastern Europe
Western Europe
Sub-Saharan Africa
North Africa
Middle East
Russia
Central Asia
East Asia
South Asia
South East Asia
Japan
Australia or New Zealand
Other (please specify)

Answer Options

Canada

United States

Mexico

Central America

South America

Eastern Europe

Western Europe

North Africa

Middle East

Central Asia

East Asia

South Asia

South East Asia

Australia or New Zealand

Other (please specify)

\section{Response \\ Percent}

$2.0 \%$

$93.9 \%$

$0.0 \%$

$0.0 \%$

$0.0 \%$

$0.0 \%$

$4.1 \%$

$0.0 \%$

$0.0 \%$

$0.0 \%$

$0.0 \%$

$0.0 \%$

$0.0 \%$

$0.0 \%$

$0.0 \%$

$0.0 \%$

$0.0 \%$

answered question skipped question
Response Count

1

46

0

0

0

0

2

0

0

0

0

0

0

0

0

0

0

0

7. How would you best describe your role in the company's decision-making process to expand operations abroad?

\section{Answer Options}

I am the sole decision maker

I make the final decision with input from staff/management

I help reach the final decision as part of a group/committee

I provide input toward the final decision

I have no input into the final decision

\section{Response \\ Percent}

$10.2 \%$

$12.2 \%$

$36.7 \%$

$20.4 \%$

$20.4 \%$

answered question

skipped question

\section{Response}

Count

5

6

18

10

10

8. Does your company currently have operations in developing countries? (NOT: Western Europe, United States, Canada, Australia, Japan) 


$\begin{array}{lcc}\text { Answer Options } & \text { Response } & \text { Response } \\ \text { Count }\end{array}$

9. Did your company have operations in developing countries in the past?

Answer Options

Yes

No

\section{Response \\ Percent}

$10.0 \%$

$90.0 \%$

answered question

skipped question
Response

Count

1

9

10. Why doesn't your company currently have operations in developing countries?

\section{Answer Options}

Weak property right protections

Political instability

Customer base is in developed countries

Government interference in business operations

Lack of judicial independence

Other (please specify)

\section{Response}

Percent

$42.9 \%$

$0.0 \%$

$85.7 \%$

$0.0 \%$

$14.3 \%$

answered question skipped question
Number Other (please specify)

\section{Categories}

1 lack of market size for data and information systems

2 Not supported by the business

We do not have suffficient product volume to establish manufacturing operations in developing countries.

3 We source product from existing manufacturers.

4 Customer base not there We retrenched to the USA only during the financial crisis, and have not yet expanded back into the developing world. Our footprint in 2007 was 11 countries.

5 We have a small revenue stream from these "old" operations, but have not yet ventured abroad again.

11. The following is a list of authoritarian countries. In which countries does your company have operations? (check all that apply)

\section{Answer Options}

Algeria

Angola

\section{Response \\ Percent}

$5.3 \%$

$2.6 \%$
Response Count

3

0

6

0

1

5 


\begin{tabular}{|c|c|c|}
\hline Armenia & $2.6 \%$ & 1 \\
\hline Azerbaijan & $2.6 \%$ & 1 \\
\hline Bahrain & $5.3 \%$ & 2 \\
\hline Bangladesh & $5.3 \%$ & 2 \\
\hline Belarus & $2.6 \%$ & 1 \\
\hline Bhutan & $0.0 \%$ & 0 \\
\hline Burkina Faso & $0.0 \%$ & 0 \\
\hline Cambodia & $0.0 \%$ & 0 \\
\hline Cameroon & $2.6 \%$ & 1 \\
\hline Central African Republic & $2.6 \%$ & 1 \\
\hline Chad & $2.6 \%$ & 1 \\
\hline China & $57.9 \%$ & 22 \\
\hline Congo Brazzaville & $0.0 \%$ & 0 \\
\hline Congo Kinshasa & $0.0 \%$ & 0 \\
\hline Cuba & $0.0 \%$ & 0 \\
\hline Djibouti & $2.6 \%$ & 1 \\
\hline Egypt & $5.3 \%$ & 2 \\
\hline Equatorial Guinea & $0.0 \%$ & 0 \\
\hline Eritrea & $0.0 \%$ & 0 \\
\hline Ethiopia & $0.0 \%$ & 0 \\
\hline Fiji & $2.6 \%$ & 1 \\
\hline Gabon & $0.0 \%$ & 0 \\
\hline Gambia & $0.0 \%$ & 0 \\
\hline Guinea & $0.0 \%$ & 0 \\
\hline Haiti & $0.0 \%$ & 0 \\
\hline Iran & $2.6 \%$ & 1 \\
\hline Iraq & $2.6 \%$ & 1 \\
\hline Ivory Coast & $0.0 \%$ & 0 \\
\hline Jordan & $7.9 \%$ & 3 \\
\hline Kazakhstan & $2.6 \%$ & 1 \\
\hline Kuwait & $7.9 \%$ & 3 \\
\hline Laos & $0.0 \%$ & 0 \\
\hline Libya & $2.6 \%$ & 1 \\
\hline Madagascar & $0.0 \%$ & 0 \\
\hline Mauritania & $0.0 \%$ & 0 \\
\hline Morocco & $2.6 \%$ & 1 \\
\hline Mozambique & $2.6 \%$ & 1 \\
\hline Myanmar (Burma) & $0.0 \%$ & 0 \\
\hline Nigeria & $2.6 \%$ & 1 \\
\hline Oman & $2.6 \%$ & 1 \\
\hline Papua New Guinea & $0.0 \%$ & 0 \\
\hline Qatar & $5.3 \%$ & 2 \\
\hline Russia & $15.8 \%$ & 6 \\
\hline Rwanda & $0.0 \%$ & 0 \\
\hline Saudi Arabia & $15.8 \%$ & 6 \\
\hline Singapore & $36.8 \%$ & 14 \\
\hline Somalia & $0.0 \%$ & 0 \\
\hline Sri Lanka & $0.0 \%$ & 0 \\
\hline Sudan & $0.0 \%$ & 0 \\
\hline Sudan & $0.0 \%$ & 0 \\
\hline Suriname & $0.0 \%$ & 0 \\
\hline Swaziland & $0.0 \%$ & 0 \\
\hline Syria & $2.6 \%$ & 1 \\
\hline Tajikistan & $2.6 \%$ & 1 \\
\hline
\end{tabular}



Tanzania
Togo
Turkmenistan
United Arab Emirates
Uganda
Uzbekistan
Venezuela
Vietnam
Yemen
Zimbabwe
My company does not currently have operations in any of
these countries

$\begin{array}{cc}0.0 \% & 0 \\ 0.0 \% & 0 \\ 2.6 \% & 1 \\ 15.8 \% & 6 \\ 0.0 \% & 0 \\ 2.6 \% & 1 \\ 5.3 \% & 2 \\ 5.3 \% & 2 \\ 0.0 \% & 0 \\ 0.0 \% & 0 \\ 28.9 \% & 11\end{array}$

answered question

skipped question
38

12. Did your company have operations in authoritarian countries in the past?

$\begin{array}{lcc}\text { Answer Options } & \text { Response } & \text { Response } \\ \text { Percent } & \text { Count } \\ \text { Yes } & 0.0 \% & 0 \\ \text { No } & 100.0 \% & 11 \\ & \text { answered question } & 11 \\ & \text { skipped question } & 42\end{array}$

13. Why doesn't your company currently have operations in any authoritarian countries?

\section{Answer Options}

Weak property right protections

Political instability

Customer base is in developed countries

Government interference in business operations

Lack of judicial independence

Other (please specify)

$\begin{array}{cc}\begin{array}{c}\text { Response } \\ \text { Percent }\end{array} & \begin{array}{c}\text { Response } \\ \text { Count }\end{array} \\ 20.0 \% & 2 \\ 20.0 \% & 2 \\ 90.0 \% & 9 \\ 40.0 \% & 4 \\ 30.0 \% & 3 \\ & 2\end{array}$

answered question skipped question

14. What is the annual revenue range of your company from operations in authoritarian countries?

Answer Options 


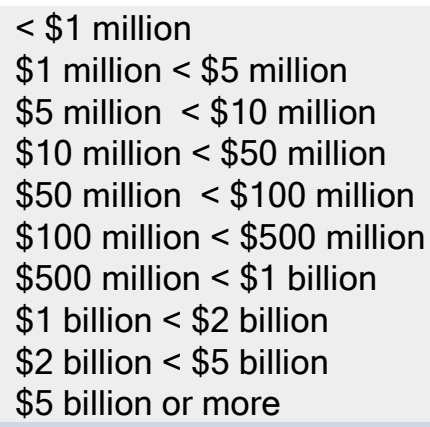

$\begin{array}{cc}4.5 \% & 1 \\ 31.8 \% & 7 \\ 22.7 \% & 5 \\ 36.4 \% & 8 \\ 4.5 \% & 1 \\ 0.0 \% & 0 \\ 0.0 \% & 0 \\ 0.0 \% & 0 \\ 0.0 \% & 0 \\ 0.0 \% & 0\end{array}$

15. Please choose one authoritarian country selected in question 9. Please type the name of this country in box below.

\section{Answer Options}

\section{Response Count}

24

$$
\begin{aligned}
& \text { answered question } \\
& \text { skipped question }
\end{aligned}
$$

\section{Response Text}

1 China

2 China

3 China

4 Saudi Arabia

5 China

6 Singapore

7 China

8 China

9 China

10 China

11 China

12 Singapore

13 Singapore

14 China

15 china

16 China

17 China

18 China

19 China

20 China

21 Singapore

22 China

23 Venezuela

24 singapore

16. Currently, how risky to the following dimensions of your business is having operations in [Q15]? 


\begin{tabular}{|c|c|c|c|c|c|c|c|c|}
\hline Answer Options & $\begin{array}{l}\text { Not } \\
\text { Risky }\end{array}$ & $\begin{array}{c}\text { A } \\
\text { Little } \\
\text { Risky }\end{array}$ & $\begin{array}{l}\text { Somewhat } \\
\text { Risky }\end{array}$ & $\begin{array}{l}\text { Very } \\
\text { Risky }\end{array}$ & $\begin{array}{l}\text { Extremely } \\
\text { Risky }\end{array}$ & $\begin{array}{l}\text { Don't } \\
\text { Know }\end{array}$ & $\begin{array}{c}\text { Not } \\
\text { Applicable }\end{array}$ & $\begin{array}{c}\text { Response } \\
\text { Count }\end{array}$ \\
\hline $\begin{array}{l}\text { Establishment of } \\
\text { Property Rights }\end{array}$ & 5 & 5 & 6 & 1 & 1 & 0 & 4 & 22 \\
\hline $\begin{array}{l}\text { Property Right } \\
\text { Security }\end{array}$ & 7 & 5 & 6 & 2 & 1 & 0 & 2 & 23 \\
\hline Contract Security & 5 & 5 & 6 & 2 & 1 & 0 & 3 & 22 \\
\hline $\begin{array}{l}\text { Intellectual Property } \\
\text { Right Security }\end{array}$ & 5 & 6 & 4 & 4 & 3 & 0 & 1 & 23 \\
\hline & & & & & & \multicolumn{2}{|c|}{$\begin{array}{l}\text { answered question } \\
\text { skipped question }\end{array}$} & $\begin{array}{l}23 \\
30\end{array}$ \\
\hline
\end{tabular}

17. Currently, how valuable to ensuring secure property right protections are the following for your company in [Q15]?

\begin{tabular}{|c|c|c|c|c|c|c|c|c|}
\hline $\begin{array}{l}\text { Answer } \\
\text { Options }\end{array}$ & $\begin{array}{c}\text { Not } \\
\text { Valuable }\end{array}$ & $\begin{array}{c}\text { A Little } \\
\text { Valuable }\end{array}$ & $\begin{array}{l}\text { Somewhat } \\
\text { Valuable }\end{array}$ & $\begin{array}{c}\text { Very } \\
\text { Valuable }\end{array}$ & $\begin{array}{l}\text { Extremely } \\
\text { Valuable }\end{array}$ & $\begin{array}{l}\text { Don't } \\
\text { Know }\end{array}$ & $\begin{array}{c}\text { Not } \\
\text { Applicable }\end{array}$ & $\begin{array}{l}\text { Response } \\
\text { Count }\end{array}$ \\
\hline $\begin{array}{l}\text { Bilateral } \\
\text { Investment } \\
\text { Treaties }\end{array}$ & 1 & 3 & 5 & 2 & 2 & 2 & 3 & 18 \\
\hline $\begin{array}{l}\text { Elected } \\
\text { Legislature } \\
\text { Stable }\end{array}$ & 4 & 2 & 0 & 2 & 3 & 2 & 5 & 18 \\
\hline $\begin{array}{l}\text { Political } \\
\text { System }\end{array}$ & 0 & 1 & 3 & 2 & 9 & 0 & 3 & 18 \\
\hline Democracy & 4 & 1 & 1 & 3 & 2 & 1 & 6 & 18 \\
\hline $\begin{array}{l}\text { Labor } \\
\text { Organizations }\end{array}$ & 8 & 2 & 0 & 1 & 0 & 1 & 5 & 17 \\
\hline $\begin{array}{l}\text { Business } \\
\text { Associations }\end{array}$ & 1 & 0 & 5 & 5 & 3 & 0 & 4 & 18 \\
\hline $\begin{array}{l}\text { Freedom of } \\
\text { Association } \\
\text { Local Citizen }\end{array}$ & 3 & 0 & 2 & 4 & 1 & 3 & 5 & 18 \\
\hline $\begin{array}{l}\text { Support for } \\
\text { Foreign } \\
\text { Investment }\end{array}$ & 2 & 1 & 7 & 4 & 1 & 0 & 3 & 18 \\
\hline $\begin{array}{l}\text { Independent } \\
\text { Court System }\end{array}$ & 4 & 0 & 1 & 3 & 6 & 0 & 4 & 18 \\
\hline & & & & & & \multicolumn{2}{|c|}{$\begin{array}{l}\text { answered question } \\
\text { skipped question }\end{array}$} & $\begin{array}{l}18 \\
35\end{array}$ \\
\hline
\end{tabular}

18. Currently, how valuable to ensuring profitable operations are the following for your company in [Q15]?

$\begin{array}{lcccccccc}\begin{array}{l}\text { Answer } \\ \text { Options }\end{array} & \begin{array}{c}\text { Not } \\ \text { Valuable }\end{array} & \begin{array}{c}\text { A Little } \\ \text { Valuable }\end{array} & \begin{array}{c}\text { Somewhat } \\ \text { Valuable }\end{array} & \begin{array}{c}\text { Very } \\ \text { Valuable }\end{array} & \begin{array}{c}\text { Extremely } \\ \text { Valuable }\end{array} & \begin{array}{c}\text { Don't } \\ \text { Know }\end{array} & \begin{array}{c}\text { Not } \\ \text { Applicable }\end{array} & \begin{array}{c}\text { Response } \\ \text { Count }\end{array} \\ \begin{array}{l}\text { Investment } \\ \text { Treaties }\end{array} & 2 & 6 & 4 & 3 & 2 & 0 & 1 & 18 \\ \begin{array}{l}\text { Elected } \\ \text { Legislature }\end{array} & 6 & 4 & 3 & 0 & 1 & 2 & 2 & 18 \\ \begin{array}{l}\text { Stable } \\ \text { Political }\end{array} & 1 & 2 & 4 & 7 & 3 & 0 & 1 & 18\end{array}$




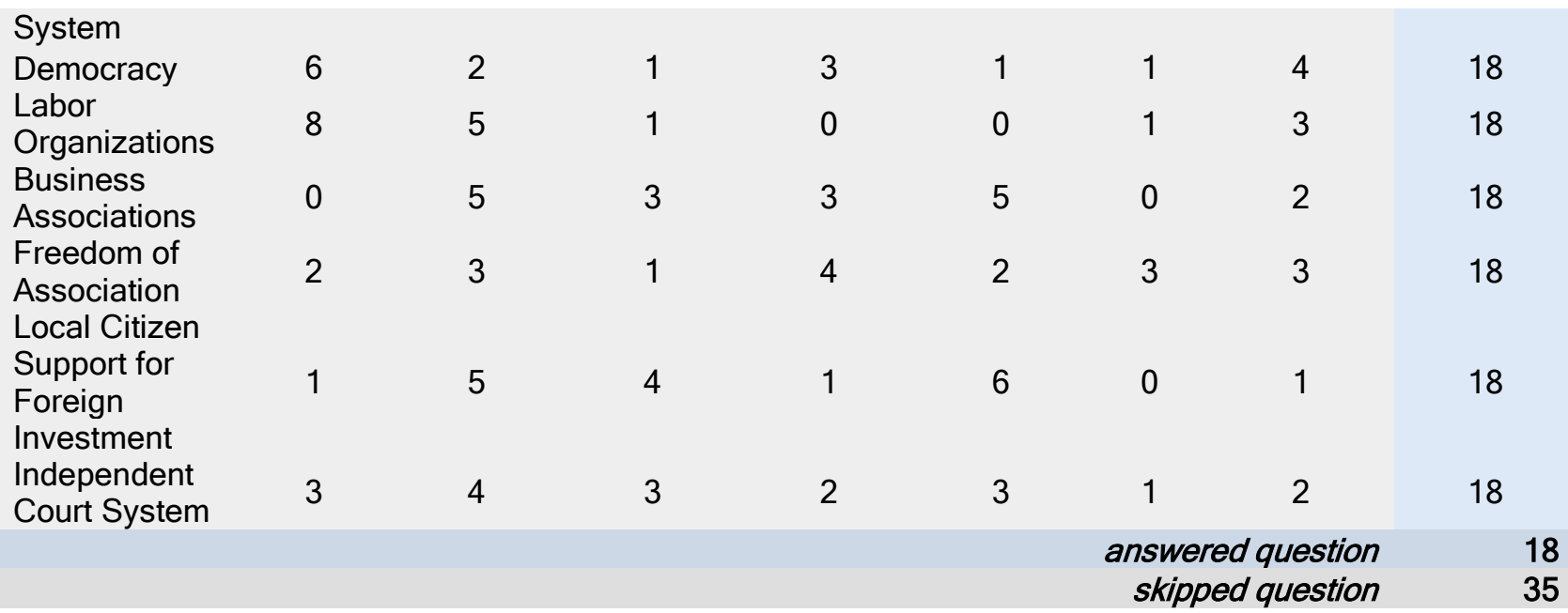

19. Currently, how valuable are bilateral investment treaties signed by [Q15] in signaling this country's commitment to liberal economic policies?

Answer Options

Not Valuable

A Little Valuable

Somewhat Valuable

Very Valuable

Extremely Valuable

Don't Know

Not Applicable

$\begin{array}{cc}\text { Response } & \text { Response } \\ \text { Percent } & \text { Count }\end{array}$

$16.7 \%$

3

$16.7 \%$

$44.4 \%$

$11.1 \%$

$5.6 \%$

$5.6 \%$

$0.0 \%$

answered question

skipped question

20. In [Q15] in the past five years, how often does your company work with the following organizations?

$\begin{array}{lccccccc}\text { Answer Options } & \begin{array}{c}\text { Every } \\ \text { Day }\end{array} & \begin{array}{c}\text { Once } \\ \mathbf{a} \\ \text { Week }\end{array} & \begin{array}{c}\text { Once } \\ \mathbf{a} \\ \text { Month }\end{array} & \begin{array}{c}\text { Once } \\ \text { a Year }\end{array} & \begin{array}{c}\text { Don't } \\ \text { Know }\end{array} & \begin{array}{c}\text { Not } \\ \text { Applicable }\end{array} & \begin{array}{c}\text { Response } \\ \text { Count }\end{array} \\ \text { Labor Organizations } & 0 & 0 & 4 & 1 & 5 & 8 & 18 \\ \text { Business Organizations } & 3 & 4 & 9 & 2 & 0 & 0 & 18 \\ \text { Chambers of Commerce } & 0 & 0 & 7 & 3 & 4 & 4 & 18 \\ \text { Non-Governmental } & 5 & 1 & 3 & 2 & 5 & 2 & 18 \\ \text { Organizations } & 1 & 0 & 3 & 3 & 1 & 10 & 18 \\ \text { Public Relations Firms } & & & & & \begin{array}{r}\text { answered question } \\ \text { skipped question }\end{array} & \mathbf{3 5}\end{array}$

21. In [Q15] in the past five years, how often does your company engage in the following activities?

$\begin{array}{ccccccccccc}\text { Answer } & \text { Every } & \text { Once } & \text { More } & \text { Once } & \text { More } & \text { Once } & \text { More } & \text { Don't } & \text { Not } & \text { Response } \\ \text { Options } & \text { Day } & \text { W } & \text { than } & \text { a } & \text { than } & \text { a } & \text { than } & \text { Know } & \text { Applicable } & \text { Count }\end{array}$




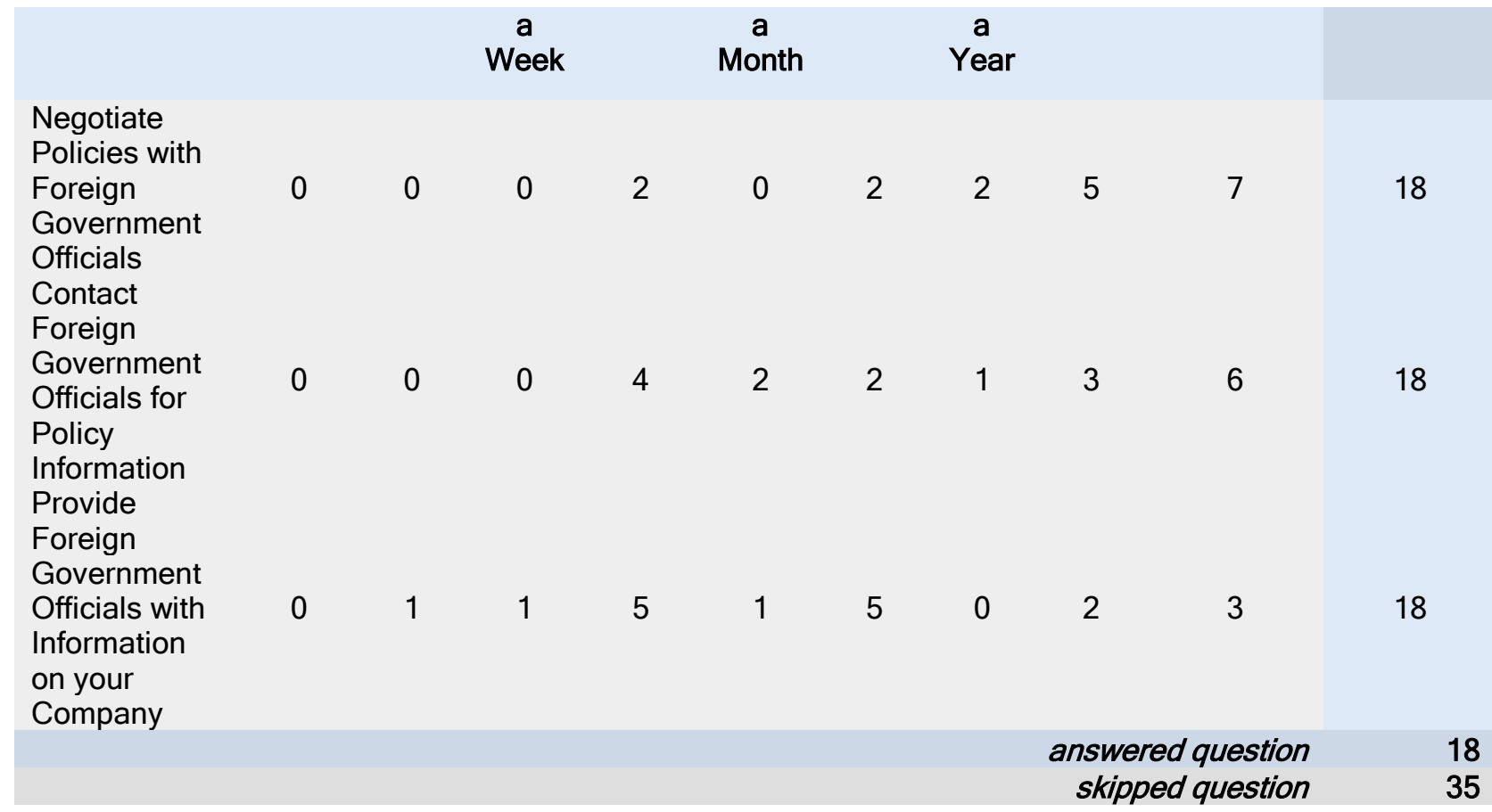

22. Currently, how valuable are local business associations in providing the following services to your company in [Q15]?

\begin{tabular}{|c|c|c|c|c|c|c|c|c|}
\hline $\begin{array}{l}\text { Answer } \\
\text { Options }\end{array}$ & $\begin{array}{c}\text { Not } \\
\text { Valuable }\end{array}$ & $\begin{array}{c}\text { A Little } \\
\text { Valuable }\end{array}$ & $\begin{array}{l}\text { Somewhat } \\
\text { Valuable }\end{array}$ & $\begin{array}{c}\text { Very } \\
\text { Valuable }\end{array}$ & $\begin{array}{l}\text { Extremely } \\
\text { Valuable }\end{array}$ & $\begin{array}{l}\text { Don't } \\
\text { Know }\end{array}$ & $\begin{array}{c}\text { Not } \\
\text { Applicable }\end{array}$ & $\begin{array}{c}\text { Response } \\
\text { Count }\end{array}$ \\
\hline $\begin{array}{l}\text { Information } \\
\text { on Host } \\
\text { Country } \\
\text { Markets }\end{array}$ & 1 & 4 & 6 & 2 & 3 & 0 & 2 & 18 \\
\hline $\begin{array}{l}\text { Information } \\
\text { on Host } \\
\text { Country } \\
\text { Regulations } \\
\text { Access to }\end{array}$ & 1 & 5 & 4 & 3 & 3 & 0 & 2 & 18 \\
\hline $\begin{array}{l}\text { Government } \\
\text { Networks } \\
\text { Access to }\end{array}$ & 2 & 3 & 4 & 2 & 3 & 1 & 3 & 18 \\
\hline $\begin{array}{l}\text { Business } \\
\text { Networks }\end{array}$ & 0 & 4 & 4 & 5 & 3 & 0 & 2 & 18 \\
\hline & & & & & & $\begin{array}{r}\text { answer } \\
\text { skipp }\end{array}$ & $\begin{array}{l}\text { ed question } \\
\text { ed question }\end{array}$ & $\begin{array}{l}18 \\
35\end{array}$ \\
\hline
\end{tabular}

23. Currently, in [Q15], how strong is citizen support for foreign investment?

Answer Options

Very Weak

Weak

Moderate

$\begin{array}{cc}\begin{array}{c}\text { Response } \\ \text { Percent }\end{array} & \begin{array}{c}\text { Response } \\ \text { Count }\end{array} \\ 5.6 \% & 1 \\ 5.6 \% & 1 \\ 38.9 \% & 7\end{array}$




$\begin{array}{lccc}\text { Strong } & 33.3 \% & 6 \\ \text { Very Strong } & 11.1 \% & 2 \\ \text { Don't Know } & 5.6 \% & 1 \\ \text { Not Applicable } & 0.0 \% & 0 & \\ & \text { answered question } & 18 \\ & \text { skipped question } & 35\end{array}$

24. Please provide any additional comments or concerns.

Answer Options

Response Count

2

answered question

skipped question

Number Response Text

i have answered to the best of our ability, these are all educated guesses so

1 completely self stated.

You should have provided a "Never" in some of the time frame questions. We never contact foreign governments, chambers of commerce, etc. on a business

2 level. Our only contact is when we ship through customs. 


\section{BIBLIOGRAPHY}

Aisbett, Emma. 2007. "Bilateral Investment Treaties and Foreign Direct Investment: Correlation versus Causation." MPRA Paper No 2255.

Aitken, Brian, Ann Harrison, and Robert E. Lipsey. 1996. "Wages and Foreign Ownership: A Comparative Study of Mexico, Venezuela, and the United States." Journal of International Economics. 40: 345-371

Allee, Todd and Clint Peinhardt. 2011. "Contingent Credibility: The Impact of Investment Treaty Violations on Foreign Direct Investment." International Organization. 65(3): 401-432.

Allee, Todd and Clint Peinhardt. 2010. "Delegating Differences: Bilateral Investment Treaties and Bargaining Over Dispute Resolution Provisions." International Studies Quarterly. 54: $1-26$.

Asia Europe Survey. 2001. http://www.icpsr.umich.edu/icpsrweb/ICPSR/studies/22324

Asiedu, Elizabeth. 2006. "Foreign Direct Investment in Africa: The Role of Natural Resources, Market Size, Government Policy, Institutions and Political Instability." United Nations University.

Baaklini, Abdo, Guilain Denoeux, and Robert Springborg. 1999. Legislative Politics in the Arab World. Boulder: Lynne Reinner Publishers.

Baunsgaard, Thomas, Mauricio Villafuerte, Marcos Poplawski-Ribeiro, and Christine Richmond. 2012. "Fiscal Frameworks for Resource Rich Developing Countries." IMF Staff Discussion Note. May 16.

Benassy-Quere, Agnes, Maylis Coupet, and Thierry Mayer. 2007. "Institutional Determinants of Foreign Direct Investment." The World Economy.

Bianchi, Robert. 1985. "Businessmen's Associations in Egypt and Turkey." Annals of the American Academy of Political and Social Science. 482: 147-159.

Biglaiser, Glen and Joseph L. Staats. 2010. "Do Political Institutions Affect Foreign Direct Investment? A Survey of U.S. Corporations in Latin America." Political Research Quarterly. 63 (3). 
Biglaiser, Glen and Joseph L. Staats. 2012. "Foreign Direct Investment in Latin America: The Importance of Judicial Strength and Rule of Law." International Studies Quarterly. 56: 193-202.

Blanton, Robert G. and Shannon L. Blanton. 2011. "Women’s Rights and Foreign Direct Investment: An Empirical Assessment.” Presented at APSA Annual Conference, Seattle, Washington.

Brambor, Thomas, William Roberts Clark, and Matt Golder. 2006."Understanding Interaction Models: Improving Empirical Analyses." Political Analysis. 14: 63-82.

Braun, Joachim von and Ruth Meinzen-Dick. 2009. "'Land Grabbing' by Foreign Investors in Developing Countries: Risks and Opportunities." International Food Policy Research Institute Policy Brief 13. April.

Bueno de Mesquita, Bruce and Alastair Smith. 2010. "Leader Survival, Revolutions, and the Nature of Government Finance." American Journal of Political Science. 54(4): 936-950.

Busse, Matthias and Carsten Hefeker. 2007. "Political Risk, Institutions and Foreign Direct Investment." European Journal of Political Economy. 23: 397-415.

Buthe, Tim and Helen V. Milner. 2008. "The Politics of Foreign Direct Investment into Developing Countries: Increasing FDI through International Trade Agreements?" American Journal of Political Science. 52 (4): 741-762.

Buthe, Tim and Helen V. Milner. 2009. "Bilateral Investment Treaties and Foreign Direct Investment: A Political Analysis." in The Effect of Treaties on Foreign Direct Investment: Bilateral Investment Treaties, Double Taxation Treaties, and Investment Flows. Karl P. Sauvant and Lisa E. Sachs, Eds. NY: Oxford University Press.

Cammett, Melani. 2005. "Fat Cats and Self-Made Men: Globalization and the Paradoxes of Collective Action." Comparative Politics. 37(4): 379-400.

Carapico, Sheila. 2010. "Civil Society.” In Politics and Society in the Contemporary Middle East. Ed., Michele Penner Angrist. Boulder: Lynne Rienner Publishers.

Carroll, Katherine Blue. 2003. Business as Usual? Economic Reform in Jordan. NY: Lexington Books.

Chandra, Siddharth and Nita Rudra. 2011. Reassessing the Links Between Regime Type and Economic Performance: Why some Authoritarian Regimes Show Stable Growth and Others Do Not." Working Paper.

Chappell, Henry W. 1990. "Economic Performance, Voting, and Political Support: A Unified Approach." The Review of Economics and Statistics. 72(2): 313-320.

Chua. 2003. “Tax Reform in Russia.” In Russia Rebounds. Eds, David Edwin Wynn Owen and David O. Robinson. International Monetary Fund. 
Cheibub, Jose, Jennifer Gandhi, and James Raymond Vreeland. 2009. "Democracy and Dictatorship Revisited.” Public Choice. 143: 67-101.

Chinn, Menzie and Hiro Ito. 2008. “A New Measure of Financial Openness.” Journal of Comparative Policy Analysis. 10 (3).

Cingranelli-Richards (CIRI) Human Rights Dataset. 2008. http://ciri.binghamton.edu/index.asp

Collier, Paul, Rick Van Der Ploeg, Michael Spence, and Anthony J. Venables. 2010. "Managing Resource Revenues in Developing Economies.” IMF Staff Papers. 57(1).

Conrad, Courtenay R. 2011. "Constrained Concessions: Beneficent Dictatorial Responses to the Domestic Political Opposition." International Studies Quarterly. 1-21.

Cook, Timothy E. and Paul Gronke. 2005. "The Skeptical American: Revisiting the Meanings of Trust in Government and Confidence in Institutions." Journal of Politics.67(3): 784-803.

Dai, Xinyuan. 2005. "Why Comply? The Domestic Constituency Mechanism." International Organization. 59(2): 363-398.

Daude, Christian and Ernesto Stein. 2007. "The Quality of Institutions and Foreign Direct Investment." Economics and Politics. 19 (3).

Deininger, Klaus and Derek Byerlee. 2011. "Rising Global Interest in Farmland: Can it Yield Sustainable and Equitable Benefits?” World Bank. http://siteresources.worldbank.org/INTARD/Resources/ESW_Sept7_final_final.pdf

Desai, Raj M., Anders Olofsgard, and Tarik M. Yousef. 2009. "The Logic of Authoritarian Bargains." Economics and Politics. 21(1).

Desbordes, Randolphe and Vincent Vicard. 2009. "Foreign Direct Investment and Bilateral Investment Treaties: An International Political Perspective." Journal of Comparative Economics. 37.

Desert Line Projects LLC v. Republic of Yemen. 2005. ICSID Case No. ARB/05/17.

Diamond, Larry Jay. 2002. "Thinking about Hybrid Regimes." Journal of Democracy. 13(2).

Dickson, Bruce J. 2003. Red Capitalists in China. Cambridge: Cambridge University Press.

Donati, Caroline. 2012. "The Economics of Authoritarian Upgrading in Syria.” In Middle East Authoritarianisms. Eds, Steven Heydemann and Reinoud Leenders. Stanford: Stanford University Press.

Doner, Richard F. and Ben Ross Schneider. 2000. "Business Associations and Economic Development: Why Some Associations Contribute More Than Others." Business and Politics. 2(3). 
Dreiling, Michael and Derek Darves. 2011. "Corporate Unity in American Trade Policy: A Network Analysis of Corporate-Dyad Political Action." American Journal of Sociology. 116(5): 1514-63.

Dryzek, John S. 2009. "Democratization as Deliberative Capacity Building." Comparative Political Studies. 42.

Egan, Partick J.W. 2010. "Hard Bargains: The Impact of Multinational Corporations on Economic Reforms in Latin America." Latin American Politics and Society. 52(1).

Egger, Peter, and Hannes Winner. 2005. "Evidence on Corruption as an Incentive for Foreign Direct Investment” European Journal of Political Economy 21 (4): 932-952,

Elkins, Zachary, Andrew T. Guzman, and Beth A. Simmons. 2006. "Competing for Capital: The Diffusion of Bilateral Investment Treaties, 1960-2000." IO. 60: 811-846.

Espinal, Rosario, Jonathan Hartlyn, and Jana Moran Kelly. 2005. "Performance Still Matters: Explaining Trust in Government in the Dominican Republic." Comparative Political Studies. 39: 200.

Evans, Peter. 1979. Dependent Development. Princeton: Princeton Unviersity Press.

Fang, Songying and Erica Owen. 2011. "International Institutions and Credible Commitment of Non-Democracies." Rev Int Organ. 6: 141-162.

Fearon, James D.1997. "Signaling Foreign Policy Interests: Tying Hands versus Sinking Costs." The Journal of Conflict Resolution. 41(1): 68-90.

Franck, Susan. 2005-6. "The Nature and Enforcement of Investor Rights under Investment Treaties: Do Investment Treaties have a Bright Future?" U.C. David Journal of International Law and Policy. 47.

Frieden, Jeffry A. 1991. "Invested Interests: The Politics of National Economic Policies in a World of Global Finance." International Organization. 45: 425-51.

Friedrich, Carl J. and Zbigniew Brzezinski. 1961. Totalitarian Dictatorship and Autocracy. New York: Praeger.

Frye, Timothy. 2004. "Credible Commitment and Property Rights: Evidence from Russia." American Political Science Review. 98(3).

Gandhi, Jennifer. 2008. Political Institutions under Dictatorship. NY: Cambridge University Press.

Gandhi, Jennifer and Adam Przeworski. 2006. "Cooperation, Cooptation, and Rebellion under Dictatorships." Economics and Politics. 18 (1). 
Gandhi, Jennifer and Adam Przeworski. 2007. "Authoritarian Instituions and the Survival of Autocrats." Comparative Political Studies. 40(11): 1279-1301.

Gao, Jie. 2012. "How Does Chinese Local Government Respond to Citizen Satisfaction Surveys? A Case Study of Foshan City." The Australian Journal of Public Administration. 71(2): 136-147.

Geddes, Barbara. 2003. Paradigms and Sandcastles: Theory Building and Research Design in Comparative Politics. Michigan: Unviersity of Michigan Press.

Gerring, John. 2007. Case Study Research: Principles and Practices. NY: Cambridge University Press.

George, Alan. 2003. Syria: Neither Bread nor Freedom. NY: Zed Books.

Globerman, Steven and Daniel Shapiro. 2002. "Global Foreign Direct Investment Flows: The Role of Governance Infrastructure." World Development. 30 (11).

Gorg, Holger, Eric Strobl, and Frank Walsh. 2007. "Why Do Foreign-Owned Firms Pay More? The Role of On-the-Job Training.” Review of World Economics. 143(3): 464-482

Green, Peter S. 2003. "Prague to Pay Award to Lauder Company." New York Times. March 15.

Haber, Stephen, Armando Razo, and Noel Maurer. 2003. The Politics of Property Rights. Cambridge: Cambridge University Press.

Habib, Mohsin and Leon Zurawicki. 2002. "Corruption and Foreign Direct Investment." Journal of International Business Studies. 33(2).

Haddad, Bassam. 2011. "The Political Economy of Syria: Reaities and Challenges.” Middle East Policy. VVIII (2).

Haddad, Bassam. 2012. Business Networks in Syria. Stanford: Stanford University Press.

Hadenius, Axel and Jan Teorell. 2007. "Pathways from Authoritarianism." Journal of Democracy. 18(1): 143-157.

Hallward-Driemeier, Mary. 2003. "Do Bilateral Investment Treaties Attract FDI? Only a bit... and they could bite." http://ideas.repec.org/p/wbk/wbrwps/3121.html

Hansen, Henrik and John Rand. 2006. "On the Causal Links Between FDI and Growth in Developing Countries.” United Nations University.

Henisz, Witold J. 2000. "The Institutional Environment for Economic Growth." Economics and Politics.12(1): 1-31.

Henisz, Witold J. 2004. "Political Institutions and Policy Volatility." Economics and Politics. 16(1). 
Hinnebusch, Raymond. 2012. “Syria: from 'Authoritarian Upgrading' to Revolution?” International Affairs. 88(1): 95-113.

Hiscox, Michael J. 2001. "Class Versus Industry Cleavages: Inter-Industry Factor Mobility and the Politics of Trade." International Organization. 55: 1-46.

Honaker, James, Gary King, and Matthew Blackwell. 2011. "Amelia II: A Program for Missing Data." Journal of Statistical Software. 45(7).

Howard, Marc Morje and Philip G Roessler. 2006. "Liberalizing Electoral Outcomes in Competitive Authoritarian Regimes." American Journal of Political Science. 50(2): 365381.

Jensen, Nathan M. 2003. "Democratic Governance and Multinational Corporations: Political Regimes and Inflows of Foreign Direct Investment.” International Organization 57 (Summer): 587-616.

Jensen, Nathan. 2008. "Political Risk, Democratic Institutions, and Foreign Direct Investment." Journal of Politics. 70(4): 1040-1052.

Jensen, Nathan, Edmund J. Malesky and Stephen Weymouth. 2012. "Unbundling the Relationship between Authoritarian Legislatures and Political Risk." Revise and Resubmit. http://faculty.msb.edu/sw439/documents/Authoritarian\%20Institutions3.5.12.pdf

Jensen, Nathan, Glen Biglaiser, Quan Li, Edmund Malesky, Pablo Pinto, Santiago Pinto, and Joseph Staats. 2012. Politics and Foreign Direct Investment. Ann Arbor: University of Michigan Press.

"Jordan King Hails FTA with S'pore." The Strait Times (Singapore). May 18, 2004.

Khadiagala, Lynn S. 2001. "The Failure of Popular Justice in Uganda: Local Councils and Women's Property Rights." Development and Change. 32: 55-76.

Kennedy, Scott. 2009. "Comparing Formal and Informal Lobbying Practies in China." China Information. XXIII(2).

Kenyon, Thomas and Megumi Naoi. 2010. "Policy Uncertainty in Hybrid Regimes: Evidence from Firm-Level Surveys.” Comparative Political Studies. 43(4): 486-510.

Kerner, Andrew. 2009. "Why Should I Believe You? The Costs and Consequences of Bilateral Investment Treaties." International Studies Quarterly. 53.

Kim, Wonik and Jennifer Gandhi. 2010. "Coopting Workers Under Dictatorship." Journal of Politics. 72 (3).

Knowles, Warwick. 2005. Jordan Since 1989: A Study in Political Economy. NY: I.B. Tauris. 
Kobrin, Stephen J. 1979. "Political Risk: A Review and Reconsideration." Journal of International Business Studies. 10(1): 67-80.

Lawson, Fred H. 2010. "Syria.” In Politics and Society in the Contemporary Middle East. Ed., Michele Penner Angrist. Boulder: Lynne Rienner Publishers.

Leib, Ethan J. and Baogang He, eds. 2006. The Search for Deliberative Democracy in China. NY: Palgrave Macmillian.

Levitsky, Steve and Lucan A. Way. 2002. "The Rise of Competitive Authoritarianism." Journal of Democracy. 13 (2).

Li, Quan. 2006. "Democracy, Autocracy, and Tax Incentives to Foreign Direct Investors: A Cross-National Analysis.” Journal of Politics. 68 (1).

Li, Quan. 2009a. "Democracy, Autocracy, and Expropriation of Foreign Direct Investment." Comparative Political Studies. 42(8): 1098-1127.

Li, Quan. 2009b. "Outlier, Measurement, and the Democracy-FDI Controversy." Quarterly Journal of Political Science. 4(2): 167-181.

Li, Quan and Adam Resnick. 2003. "Reversal of Fortunes: Democratic Institutions and Foreign Direct Investment Inflows to Developing Countries.” International Organization 57 (Winter): 175-211

Linardi, Sera and Nita Rudra. 2012. "Globalization and Perceptions of Upward Mobility in Developing Countries: An Experimental Study." IPSA Conference Paper.

Linz, Juan J. 2000. Totalitarian and Authoritarian Regimes. Boulder: Lynne Rienner Publishers.

Lucas, John. 1997. "The Politics of Business Associations in the Developing World." The Journal of Developing Areas. 32(1): 71-96.

Lust-Okar, Ellen. 2005. Structuring Conflict in the Arab World. Cambridge: Cambridge University Press.

Magaloni, Beatriz. 2008. "Credible Power-Sharing and the Longevity of Authoritarian Rule." Comparative Political Studies. 41 (4/5): 715-741.

Mansfield, Edward D., and Eric Reinhardt. 2008. "International Institutions and the Volatility of International Trade." International Organization 62, 4 (October): 621-652.

Mansfield, Edward D., Helen V. Milner, and B. Peter Rosendorff. 2002. Why Democracies Cooperate More: Electoral Control and International Trade Agreements. International Organization. 56(3): 477-513.

Marshall, Monty G. and Ted Robert Gurr. 2008. Polity IV Project. http://www.nsd.uib.no/macrodataguide/set.html?id=32\&sub=1 
Mathur, Aparna and Kartikeya Singh. 2013. "Foreign Direct Investment, Corruption, and Democracy." Applied Economics. 45(8): 991-1002.

McGillivray, Fiona and Alastair Smith. 2006. "Credibility in Compliance and Punishment: Leader Specific Punishments and Credibility." Journal of Politics. 68(2): 248-258.

Mihalache-O’Keef and Li. 2011. “Modernization versus Dependency Revisited: Effects of Foreign Direct Investment on Food Security in Less Developed Countries.” International Studies Quarterly. 55.

Milton-Edwards, Beverly and Peter Hinchcliffe. 2009. Jordan: A Hashemite Legacy. 2nd ed. NY: Routledge.

Mishler, William and Anne Hildreth. 1984. "Legislatures and Political Stability." The Journal of Politics. 46(1): 25-59.

Moore, Peter W. 2000. "Business-State Relations after Liberalization in Jordan." in Economic Liberalization, Democratization and Civil Society in the Developing World. Remonda Bansabat Kleinberg and Janine A. Clark, Eds. NY: St Martin's Press.

Mosley, Layna. 2011. Labor Rights and Multinational Production. NY: Cambridge University Press.

Mosley, Layna and Saika Uno. 2007. "Racing to the Bottom or Climbing to the Top? Economic Globalization and Collective Labor Rights." Comparative Political Studies. 40: 923.

Musteen, Martina, Lawrence Rhyne, and Congcong Zheng. 2012. "Asset or Constraint: Corporate Reputation and MNCs' involvement in the Least Developed Countries." Journal of World Business.

Neumayer, Eric and Laura Spess. 2005. "Do Bilateral Investment Treaties Increase Foreign Direct Investment to Developing Countries?" World Development. 33 (10): 1567-85.

Noorbakhsh, Farhod, Alberto Paloni, and Ali Youssef. 2001. "Human Capital and FDI Inflows to Developing Countries: New Empirical Evidence." World Development. 29(9): 15931610.

North, Douglass. 1990. Institutions, Institutional Change, and Economic Performance. Cambridge: Cambridge University Press.

North, Douglass and Barry R. Weingast. 1989. "Constitutions and Commitment: The Evolution of Institutional Governing Public Choice in Seventeenth-Century England." The Journal of Economic History. 49(4): 803-832.

Nevitt, Christopher Earle. 1996. "Private Business Associations in China: Evidence of Civil Society or Local State Power?" The China Journal. 36: 25-43.

Ogden, Suzanne. 2002. Inklings of Democracy in China. Cambridge: Harvard University Press. 
Olson, Mancur. 1993. "Dictatorship, Democracy, and Development." American Political Science Review. 87 (3).

Oneal, John R. 1994. "The Affinity of Foreign Investors for Authoritarian Regimes." Political Research Quarterly. 47.

Pateman, Carole. 2012. "Participatory Democracy Revisited." Perspectives on Politics. 10(1): 719.

PEW. 2003. Global Attitudes Project. http://www.pewglobal.org/

PEW. 2007. Global Attitudes Project. http://www.pewglobal.org/

Political Risk Services. 2011. International Country Risk Guide. http://www.prsgroup.com/

Przeworski, Adam, Michael E. Alvarez, Jose Antonio Cheibub, and Fernando Limongi. 2000. Democracy and Development. Cambridge: Cambridge University Press.

Przeworski, Adam and Henry Teune. 1970. The Logic of Comparative Social Inquiry. New York: Wiley-Interscience.

Pyle, William. 2006. "Collective Action and Post-Communist Enterprise: The Economic Logic of Russia's Business Associations." Europe-Asia Studies. 58(4): 491-521.

Qian, Xingwan and Kyeonghi Baek. 2011. "An Analysis on Political Risks and the flow of Foreign Direct Investment in Developing and Industrialized Economies." Economics, Management, and Financial Markets. 4.

Quinn, Dennis P. and John T. Woolley. 2001. "Democracy and National Economic Performance: The Preference for Stability." American Journal of Political Science. 45(3): 634-57.

Rogowski, Ronald. 1987. "Political Cleavages and Changing Exposure to Trade." American Political Science Review. 81: 1121-37.

Romero, Vidal F. 2004. "Developing Countries." in Public Opinion and Polling Around the World: A Historical Encyclopedia, Ed. John G. Geer. Santa Barbara: ABC_CLIO.

Rosendorff, B. Peter and Kongjoo Shin. 2011. "Importing Transparent Institutions: The Political Economy of BITs and FDI Flows." APSA Annual Meeting. Working Paper.

Ross, Michael. 2012. The Oil Curse: How Petroleum Shapes the Development of Nations. Princeton: Princeton University Press.

Rubin, D.B. 1987. Multiple Imputation for Nonresponse in Surveys. New York: Wiley.

Ryan, Curtis R. 2010. “Jordan.” In Politics and Society in the Contemporary Middle East. Ed., Michele Penner Angrist. Boulder: Lynne Rienner Publishers. 
Salacuse, Jeswald and Nicholas P. Sullivan. 2005. "Do BITs Really Work? An Evaluation of Bilateral Investment Treaties and their Grand Bargain." Harvard International Law Journal. 46.

Scheve, Kenneth and Matthew J. Slaughter. 2004. "Economic Insecurity and the Globalization of Production." American Journal of Political Science 48 (4):662-674.

Schneider, Ben Ross and Sylvia Maxfield, eds. 1997. Business and the State in Developing Countries. Ithaca: Cornell University Press.

Schneider, Friedrich and Bruno S. Frey. 1985. "Economic and Political Determinants of Foreign Direct Investment." World Development. 13(2): 161-175.

Skocpol, Theda and Margaret Somers. "The Uses of Comparative History in Macrosocial Inquiry.” Comparative Studies in Society and History. 22(2): 1980

Shah, Anwar, ed. 2007. Participatory Budgeting. Washington DC: World Bank.

Simmons, Beth. 2010. "Treaty Compliance and Violation." Annual Review of Political Science. 13: 273-96.

Sintomer, Yves, Carsten Herberg, and Giovanni Allegretti. 2010. "Participatory Budgeting Worldwide-- an Invitation to Global Cooperation." Dialog Global 25.

Smarzynska, Beata K. and Shang-Jin Wei. 2000. "Corruption and Composition of Foreign Direct Investment: Firm-Level Evidence." NBER Working Paper 7969.

Stasavage, David. 2002. "Private Investment and Political Institutions." Economics \& Politics 14, 1: 41-63.

Stevenson, Lois. 2010. Private Sector and Enterprise Development. Nothampton: Edward Elgar.

TeVelde, Dirk Willem and Oliver Morrissey. 2002. "Foreign Direct Investment, Skills, and Wage Inequality in East Asia." DSEG Conference Working Paper.

Tobin, Jennifer and Susan Rose-Ackerman. 2011. "When BITs have some bite: The Politicaleconomic Environment for Bilateral Investment Treaties." Rev Int Organ. 6.

Tsebelis, George. 1995. "Decision Making in Political Systems: Veto Players in Presidentialism, Parliamentarism, Multicameralism, and Multipartyism.” British Journal of Political Science. 25: 289-325.

Tseng, Wanda and Harm Zebregs. 2002. "Foreign Direct Investment in China: Some Lessons for Other Countries.” IMF Policy Discussion Paper. PDP/02/3.

UNCTAD. 2007. "Bilateral Investment Treaties: 1995-2006: Trends in Investment Rulemaking." NY: United Nations. 
UNCTAD. 2011. Country Specific Lists of BITs. http://www.unctad.org/Templates/Page.asp?intItemID=2344\&lang=1

UNCTAD. 2011b. "Inward and Outward Foreign Direct Investment Flows, Annual, 1970-2011." http://unctadstat.unctad.org/TableViewer/tableView.aspx?ReportId=88

Underdal, Arild. 1998. "Explaining Compliance and Defection: Three Models." European Journal of International Relations. 4(1): 5-30.

United Nations Educational, Scientific and Cultural Organization. 2013. "List of Conventions Ratified and Non-Ratified by Country." http://portal.unesco.org/en/ev.php-

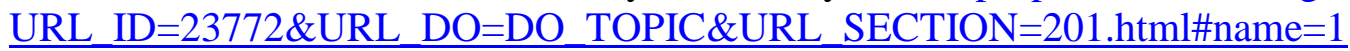

Uniworld Business Publications. 2013. "American Firms Operating in Foreign Countries." http://www.uniworldbp.com/template1.php

U.S. Congress. Senate. Committee on Foreign Relations. 2000. Treatment of U.S. Business in Eastern and Central Europe. 106th Congress, 2d session, S. Hrg. 106-823.

Vernon, Raymond. 1971. Sovereignty at Bay: The Multinational Spread of US Enterprises. New York: Basic Books.

Vreeland, James Raymond. 2008. "Political Institutions and Human Rights: Why Dictatorships Enter into the United Nations Convention Against Torture." International Organization. 62: $65-101$.

Wacziarg, Romain and Karen Horn Welch. 2008. "Trade Liberalization and Growth: New Evidence.” The World Bank Economic Review. 22(2): 187-231.

Weymouth, Stephen. 2011. "Political Institutions and Property Rights: Veto Players and Foreign Exchange Commitments in 127 Countries." Comparative Political Studies. 44(2): 211240.

Wiktorowicz, Quintan. 2000. "Civil Society as Social control: State Power in Jordan." Comparative Politics. 33(1): 43-61.

World Bank. 2005. Business Environment and Enterprise Survey. http://data.worldbank.org/data-catalog/BEEPS

World $\quad$ Bank. $2010 . \quad$ World $\quad$ Governance Indicators. http://info.worldbank.org/governance/wgi/index.asp

World Bank. 2011. World Development Indicators Database.

World Values Survey. 2000. http://www.wvsevsdb.com/wvs/WVSData.jsp

Wright, Joseph. 2008. "Do Authoritarian Institutions Constrain? How Legislatures Affect Economic Growth and Investment." American Journal of Political Science. 52 (2). 
Yackee, Jason Webb. 2007. "Conceptual Difficulties in the Empirical Study of Bilateral Investment Treaties." University of Wisconsin Legal Studies Research Paper 1053. http://papers.ssrn.com/sol3/papers.cfm?abstract_id=1015088 